UNIVERSIDADE DA BEIRA INTERIOR

Ciências da Saúde

\title{
Cyclooxygenase-2 Immunoexpression in Breast Cancer: Progesterone Receptor Influence
}

\author{
Micaela Carina Pereira Almeida \\ Dissertação para obtenção do Grau de Mestre em \\ Ciências Biomédicas \\ ( $2^{\circ}$ ciclo de estudos)
}

Orientador: Prof. Doutor José Fonseca Moutinho

Co-orientador: Prof. Doutor Javier Muñoz Moreno

Covilhã, Outubro de 2010 


\section{Agradecimentos}

Agradeço ao meu orientador, Professor Doutor José Fonseca Moutinho por propor um trabalho inovador, por toda a disponibilidade, empenho, conhecimento e exigência ao longo de toda esta dissertação.

Agradeço ao meu co-orientador, Professor Doutor Javier Muñoz Moreno por toda a disponibilidade, empenho, conhecimento e exigência ao longo de toda a dissertação.

Agradeço à técnica de anatomia patológica Catarina Ferreira por toda a disponibilidade e ajuda indispensável ao trabalho prático.

Agradeço à Professora Sara Nunes por toda a disponibilidade e ajuda à análise dos resultados.

Agradeço à Universidade da Beira Interior e ao Centro Hospitalar Cova da Beira, por contribuírem para que este trabalho fosse possível.

Uma vez que esta dissertação é o culminar de cinco anos de estudo, não poderia deixar de agradecer a todos os amigos que sempre me apoiaram, principalmente à Catarina, Margarida, Dina, Ivo, João Pedro, Marcelo, Amilcar, Liliana, Diana, André, Tiago, Gonçalo, Stephanie, Margarida G., Ana M. e Cátia.

Não poderia deixar de agradecer especialmente ao Bruno Gomes pelo apoio e paciência incansáveis ao longo de todos estes anos.

Por fim, agradeço e dedico esta dissertação aos meus pais, Dora e João, às minhas avós Angélica e Manuela, ao meu tio e padrinho Joaquim e à Maria Francisca. Não poderia deixar de referir os meus avôs Manuel e Alberto e o meu bisavô José. Porque vocês me ensinaram que na família não existe o "eu”, mas o "nós", esta dissertação também é vossa. 


\section{Resumo}

No cancro da mama a expressão de ciclooxigenase-2 está relacionada com elevados níveis locais de receptor de estrogénio, e consequente pior prognóstico, mas a relevância clínica da ciclooxigenase-2 ainda não está bem esclarecida.

Foi analisada, por imunohistoquímica, a expressão de ciclooxigenase-2 e do receptor de progesterona em 31 casos de carcinoma ductal invasivo, de doentes do Departamento da Mulher e da Criança do Centro Hospitalar Cova da Beira.

A expressão de ciclooxigenase-2 e do receptor de progesterona foi verificada em $64.5 \%$ e $54.8 \%$ dos tumores, respectivamente. Verificou-se que os tumores com expressão do receptor de progesterona tinham menores dimensões, e a maioria das mulheres com estes tumores não apresentava metastização ganglionar, quando comparados aos tumores com receptor de progesterona negativo. Foram encontrados resultados semelhantes quando se correlacionou a expressão do receptor de progesterona e de ciclooxigenase-2 com os factores clinicopatológicos.

Estes resultados sugerem que o receptor de progesterona tem uma função protectora no cancro da mama, pela modulação da via inflamatória. Os carcinomas ductais invasivos da mama que exprimem $\mathrm{COX}-\mathrm{2}^{+} / \mathrm{PR}^{+}$, têm melhor comportamento biológico, e sugerimos que a determinação da ciclooxigenase-2 poderá vir a ter utilidade na prática clínica. Estudos posteriores poderão vir a clarificar o papel da determinação imunohistoquímica da ciclooxigenase-2 no cancro da mama.

\section{Palavras-chave}

Cancro da mama, Ciclooxigenase-2, Receptor de Progesterona, Receptor de Estrogénio. 


\section{Resumo Alargado}

O processo inflamatório crónico está associado com o cancro da mama, as citocinas libertadas por esta via aumentam a expressão de ciclooxigenase-2. Esta enzima induz a produção de prostaglandinas, com consequente aumento dos níveis de aromatase e de estrogénio. Vários estudos indicam que os tumores do tipo receptor de estrogénio positivo, receptor de progesterona negativo, são os tumores mais agressivos, quando comparados com tumores com receptores de progesterona positivos. No entanto, a função do receptor de progesterona, no cancro da mama, não é clara. Neste estudo tentou-se estabelecer uma possível relação entre o receptor de progesterona e a ciclooxigenase-2, correlacionando-os com factores clinicopatológicos.

Analisou-se, por imunohistoquímica, a expressão de ciclooxigenase-2 e de receptor de progesterona, em carcinomas invasivos ductais de 31 doentes do Departamento da Mulher e da Criança do Centro Hospitalar Cova da Beira, entre os anos de 2007 e 2009. A expressão de ciclooxigenase-2 e do receptor de progesterona foram correlacionadas com factores clinicopatológicos (idade, dimensão tumoral, grau de diferenciação tumoral e metastização ganglionar).

Verificou-se, que 64.5\% $(n=20)$ dos tumores apresentavam expressão de ciclooxigenase-2 e 45.2\% $(n=14)$ dos tumores apresentavam expressão do receptor de progesterona. Quando estes dados foram correlacionados com os factores clinicopatológicos, foi possível estabelecer uma relação entre o receptor de progesterona, a dimensão tumoral e a metastização ganglionar. Obtiveram-se resultados semelhantes, quando a expressão do receptor de progesterona e a expressão de ciclooxigenase-2 foram correlacionados com os mesmos parâmetros. Verificou-se que tumores com expressão de receptor de progesterona tinham menores dimensões e o número de casos com metastização ganglionar era reduzido. Estes dados sugerem que o receptor de progesterona é um modelador da ciclooxigenase-2, podendo desempenhar uma função anti-inflamatória, no entanto, são necessários mais estudos, com maior número de casos clínicos, de modo a que doentes com cancro da mama possam beneficiar de uma terapêutica mais eficaz.

\section{Palavras-chave}

Cancro da mama, Ciclooxigenase-2, Receptor de Progesterona, Receptor de Estrogénio. 


\section{Abstract}

In breast cancer cyclooxygenase-2 expression is related with high local estrogen receptor levels and consequent poor outcomes, but the clinical relevance of cyclooxygenase- 2 is still unclear.

We analyzed, by immunostaining, cyclooxygenase-2 and progesterone receptor expression in 31 cases of women with invasive ductal carcinoma, from Child and Women department of Cova da Beira Medical Center.

Cyclooxygenase-2 and progesterone receptor expression was observed in $64.5 \%$ and $54.8 \%$ of the tumors, respectively. We verified that tumors with progesterone receptor expression had lower size and the majority of women with these tumors had no axillary node metastasis, when compared to tumors with positive progesterone receptor. Similar results were found when a correlation between progesterone receptor, cyclooxygenase- 2 and clinicopathological factors was performed.

These results suggest that progesterone receptor has a protective role in breast cancer by inflammatory pathway modulation. $\mathrm{COX}-\mathrm{2}^{+} / \mathrm{PR}^{+}$seems to be a marker of better behavior in ductal invasive breast cancer.

We speculate if cyclooxygenase-2 determination may have be a clinical usefulness in clinical practice. It's expected that further studies may clarify this issue.

\section{Keywords}

Breast cancer, Cyclooxygenase-2, Progesterone Receptor, Estrogen Receptor. 


\section{Índice}

Chapter 1: Introduction...............................................................

Inflammation and Carcinogenesis ....................................................

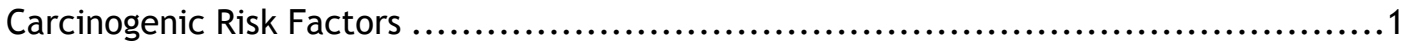

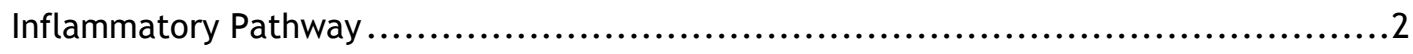

Cyclooxygenase ..................................................................6

Cyclooxygenase-2 Up-regulation Mechanisms ......................................7

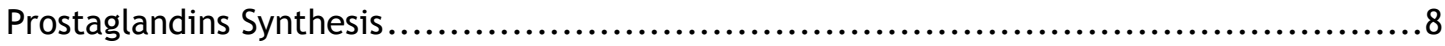

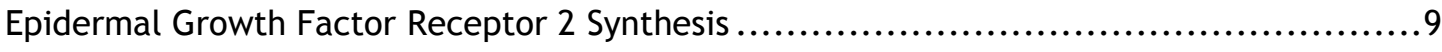

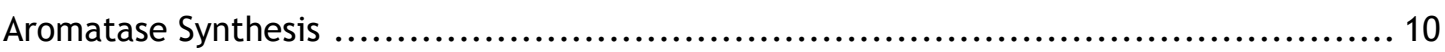

Steroid Hormone Receptors ........................................................ 11

Progesterone Receptor and Breast Cells............................................. 12

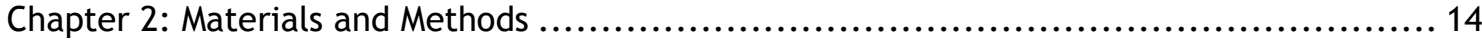

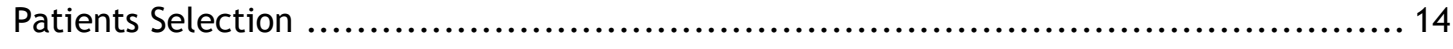

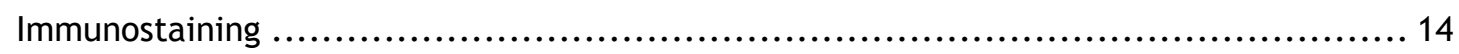

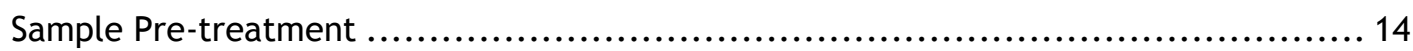

Cyclooxygenase-2 and Progesterone Receptor Immunostaining ...................... 14

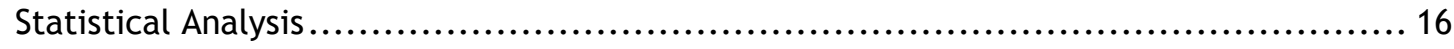

Chapter 3: Results Analysis ................................................... 17

Descriptive Statistical Analysis ................................................. 17

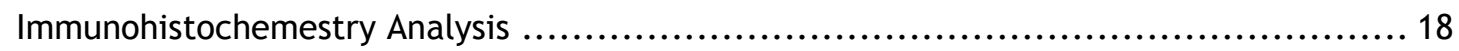

Cyclooxygenase-2 Immunoreactivity ........................................... 18

Progesterone Receptor Immunoreactivity ........................................ 18

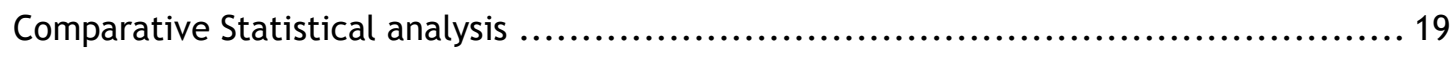

Correlation between Clinicopathologic Factors and Cyclooxygenase-2 Expression ........ 19

Correlation between Clinicopathologic Factors and Progesterone Receptor Expression . 23

Correlation between Progesterone Receptor Expression and Clinicopathologic Factors according to Cyclooxygenase-2 Expression........................................ 25

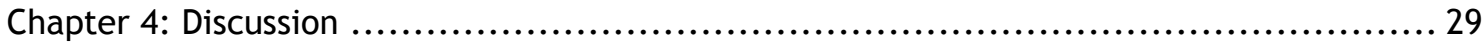

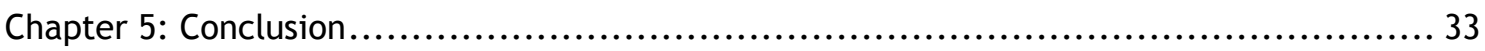

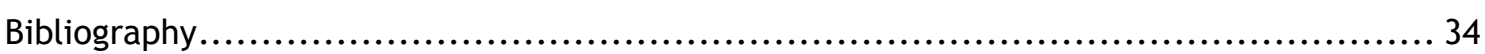

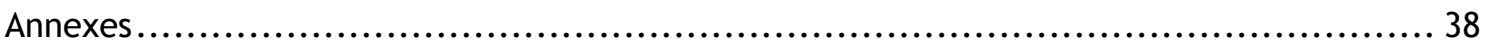

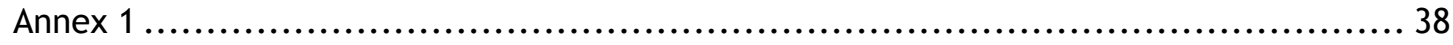

Annex 2 ........................................................................ 40

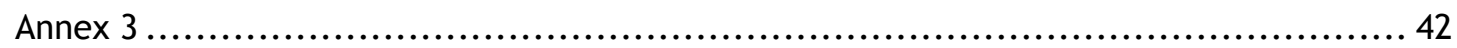

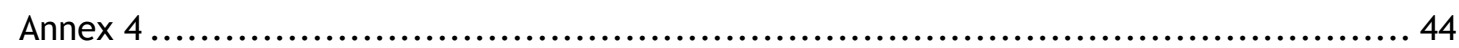




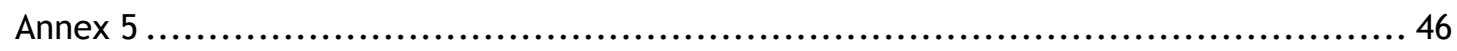

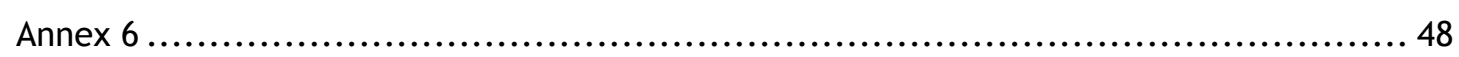

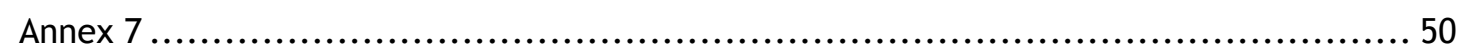

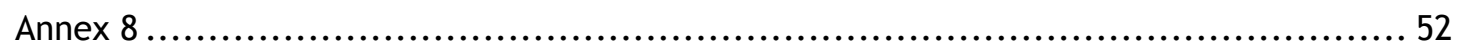

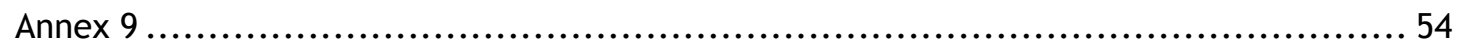

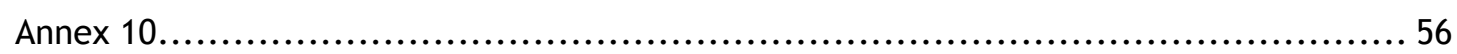

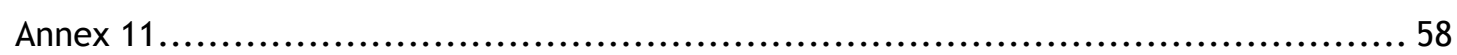

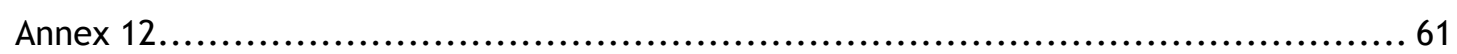

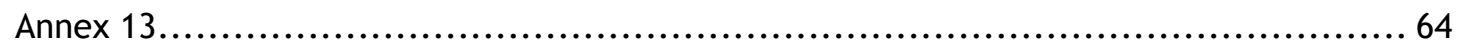

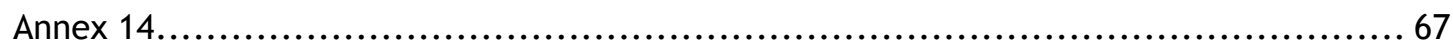

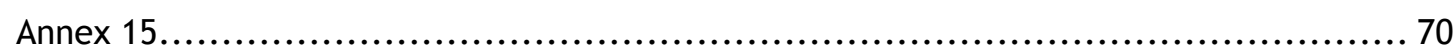




\section{Lista de Figuras}

Figure 1: Intrinsic pathway is activated by genetic events, whereas extrinsic pathway is activated by inflammatory or infectious events, both culminate on NF-KB activation, and other transcription factors, that recruit and active inflammatory cells through inflammation mediators as cytokines, more transcription factors are activated, resulting in an inflammatory micro-environment.

Figure 2: M1 class when exposed to IFN- $\gamma$ induces IL-12, IL-23 and IFN- $\gamma$, which recruit more inflammatory mediators that participate in tumor suppression, by events such as phagocytosis and apoptosis.

Figure 3: $M 2$ class when exposed to IL-4 induces IL-1, IL-6, IL-10 and TNF-a, which recruits more inflammatory mediators and transcription factors. COX-2 is expressed as a result of this mast cells class and together with other inflammatory mediators confers tumor proliferation, inhibiting apoptosis and stimulating angiogenesis.

Figure 4: COX-2 is up-regulated by PDGF that induces COX-2 via Ras/Raf-1/ERK and Ras/MEKK1/JNK, by IL-1B and TNF- $\alpha$ via PI3K/Akt and NF-KB and by LPS via MAPK and PKC- $\zeta$, these signal transduction pathways bind to COX-2 human promoter, inducing its overexpression.

Figure 5: Phospholipase $A 2$ synthesizes $A A$ from phospholipids. $A A$ is converted in PGH2 through COX-2, in turn PGH2 is converted in PG by specific isomerases.

Figure 6: HER-2 induces COX-2 up-regulation via Ras/MAPK and NF-KB, COX-2 is overexpressed and converts AA in PG. Synthesized PGE2 stimulates HER-2, suggesting a positive feedback between COX-2 and HER-2. Use of Celecoxib (COX-2 inhibitor) has proof this theory, because it inhibits PGE2 synthesis and as result HER-2 levels are diminished.

Figure 7: PGE2 induces estrogen synthesis. PGE2 via CAMP, PKA and CRE activates aromatase resulting in estrogen synthesis. 10

Figure 8: COX-2 synthesizes PGE2 which via CAMP induces CYP19 expression, resulting in estrogen synthesis by aromatase. Estrogen acts through its receptor and undergoes translocation to the nucleus where activates Scr, allowing EGF binding to its receptor. HER-2 acts through NF-KB activating COX-2 expression, and through ERK resulting in AA formation. More PGE2 is produced and as consequence more estrogen is synthesized by aromatase, suggesting a feedback between estrogen and HER-2 
Figure 9: COX-2 is expressed in chronic inflammation, converting AA into PGE, leading to aromatase increase with subsequent increase of ER and PR. PR through NF-KB inhibition results in COX-2 lower expression. 13

Figure 10: Immunohistochemical localization of COX-2 in ductal carcinoma (400 $\mathrm{x}$ magnifications). There is cytoplasmatic staining, with COX-2 light expression.

Figure 11: Immunohistochemical localization of PR in ductal carcinoma (400x magnification). There is nuclear strong staining, with PR high expression. 19

Figure 12: Correlation between COX-2 expression and age. For COX-2 negative expression the minimum value is 59 years and the maximum value is 91 years, with a mean of 75.45 years and a standard deviation of 8.251 years. For COX-2 positive expression the minimum value is 39 years and the maximum value is 87 years, with a mean of 65.65 years and a standard deviation of 16.027 years. 20

Figure 13: Correlation between COX-2 expression and tumor size. For COX-2 negative expression the minimum value is $1 \mathrm{~cm}$ and the maximum value is $9 \mathrm{~cm}$, with a mean of 3.95 $\mathrm{cm}$ and a standard deviation of $2.709 \mathrm{~cm}$. For COX-2 positive expression the minimum value is $1 \mathrm{~cm}$ and the maximum value is $15 \mathrm{~cm}$, with a mean of $3.36 \mathrm{~cm}$ and a standard deviation of $2.952 \mathrm{~cm}$.

Figure 14: Correlation between COX-2 expression and age, considering 2 groups. For COX-2 negative expression there are 4 tumors with less than $2 \mathrm{~cm}$ and 7 tumors with $2 \mathrm{~cm}$ or more. For COX-2 positive expression there are 6 cases with less than $2 \mathrm{~cm}$ and 14 cases with $2 \mathrm{~cm}$ or more.

Figure 15: Correlation between COX-2 expression and differentiation grade. For COX-2 negative expression there is 1 tumor with low differentiation grade and 10 tumors with $\mathrm{G} 2$ or G3 histologic grade. For COX-2 positive expression there are 6 tumors with low differentiation grade and 14 tumors with $\mathrm{G} 2$ or $\mathrm{G} 3$ histologic grade.

Figure 16: Correlation between COX-2 expression and axillary node metastasis. In 16 of the 20 women whose tumors overexpressed COX-2 there was no axillary node metastasis and in 4 of them there was axillary node metastasis. In tumors with negative COX-2 expression, 6 of 11 women had no axillary node metastasis and 5 of them had axillary node metastasis.

Figure 17: Correlation between PR expression and age. For PR negative expression the minimum value is 39 years and the maximum value is 81 years, with a mean of 67.59 years and a standard deviation of 11.609 years. For PR positive expression the minimum value is 39 years and the maximum value is 91 years, with a mean of 71 years and a standard deviation of 17.537 years. 
Figure 18: Correlation between PR expression and tumor size. For PR negative expression the minimum value is $1 \mathrm{~cm}$ and the maximum value is $15 \mathrm{~cm}$, with a mean of $4.60 \mathrm{~cm}$ and a standard deviation of $3.471 \mathrm{~cm}$. For PR positive expression the minimum value is $1 \mathrm{~cm}$ and the maximum value is $4 \mathrm{~cm}$, with a mean of $2.32 \mathrm{~cm}$ and a standard deviation of $0.816 \mathrm{~cm}$..... 24

Figure 19: Correlation between PR expression and differentiation grade. For PR negative expression there are 2 tumors with low differentiation grade and 15 tumors with G2 or G3 histologic grade. For PR positive expression there are 5 tumors with low differentiation grade and 9 tumors with $\mathrm{G} 2$ or $\mathrm{G} 3$ histologic grade.

Figure 20: Correlation between PR expression and axillary node metastasis. In 13 of women whose tumors expressed PR there was no axillary node metastasis and in 1 of them there was axillary node metastasis. In tumors with negative PR expression, 9 women had no axillary node metastasis and 8 of them had axillary node metastasis. 25

Figure 21: Correlation between PR expression and age according to COX-2 expression. a) The COX-2 $/ \mathrm{PR}^{-}$group is more heterogeneous than $\mathrm{COX}-2^{-} / \mathrm{PR}^{+}$group, with a standard deviation of 6.989 years. $\mathrm{COX}-2^{-} / \mathrm{PR}^{+}$has a higher mean and median than $\mathrm{COX}-2^{-} / \mathrm{PR}^{-}$group. b) $\mathrm{COX}-2^{+} / \mathrm{PR}^{+}$ group has a higher mean and standard deviation than COX-2 $/ \mathrm{PR}^{-}$group 26

Figure 22: Correlation between PR expression and tumor size according to COX-2 expression. a) The COX-2 / $\mathrm{PR}^{-}$group is more heterogeneous and has higher mean than $\mathrm{COX}-2^{-} / \mathrm{PR}^{+}$group, with a standard deviation of $2.941 \mathrm{~cm}$ and a mean of $4.60 \mathrm{~cm}$. b) $\mathrm{COX}-2^{+} / \mathrm{PR}^{+}$group has a lower mean and standard deviation than $\mathrm{COX}-2^{+} / \mathrm{PR}^{-}$group. 26

Figure 23: Correlation between PR expression and differentiation grade according to COX-2 expression. a) In COX-2 /PR group all tumors have a high differentiation grade and in COX-2 $/ \mathrm{PR}^{+}$group there is only one case with low differentiation grade. b) For COX-2 positive expression group tumors with PR positive expression have higher number of cases with low differentiation grade $(\mathrm{G} 1)$....

Figure 24: Correlation between PR expression and axillary node metastasis according to COX-2 expression. a) In COX-2 /PR there is the same number of cases with and without axillary node metastasis, for PR negative expression there are more cases without axillary node metastasis. b) COX $-2^{+} / \mathrm{PR}^{-}$has a higher number of cases with axillary node metastasis than $\mathrm{COX}-\mathrm{2}^{+} / \mathrm{PR}^{+}$ group, which has only cases without axillary node metastasis. 28 


\section{Lista de Tabelas}

Table 1: Patient characteristics: Year, Age, COX-2 expression, PR expression, Tumor Size, Differentiation Grade and Axillary Node Metastasis...................................... 17

Table 2: Correlation between COX-2 and PR expression.................................... 25 


\section{Lista de Acrónimos}

A

\begin{tabular}{ll}
\hline AA & Arachidonic acid \\
AF-1 & Activation function 1 \\
AF-2 & Activation function 2 \\
Akt & Protein Kinase B
\end{tabular}

B

BRCA1 Breast Cancer Type 1

BRCA2 Breast Cancer Type 2

C

cAMP Cyclic adenosine monophosphate

COX Cyclooxygenase

COX-1 Cyclooxygenase-1

COX-2 Cyclooxygenase-2

CRE CAMP response element

CTL Cytolytic T lymphocyte

CYP19 Cytochrome protein 450, subfamily XIX

D

DBD DNA binding domain

DC Dendritic cells

DNA Deoxyribonucleic acid

E

EGF Epidermal growth factor

ER Estrogen receptors

ERa Estrogen receptors alpha

ERB Estrogen receptors beta

ERK Extracellular signal-regulated protein kinase

H

HER-2 Human epidermal growth factor receptor 2

HIF1-a Hypoxia inducible factor 1 alpha

HRP Horseradish peroxidase

HSPG Prostaglandin H2 synthase 
I

\begin{tabular}{ll}
\hline IL-1 & Interleukine 1 \\
IL-1B & Interleukine 1beta \\
IL-4 & Interleukine 4 \\
IL-6 & Interleukine 6 \\
IL-10 & Interleukine 10 \\
IL-12 & Interleukine 12 \\
IL-23 & Interleukine 23 \\
IKB & Kappa b inhibitor \\
IFN-ץ & Interferon-gamma
\end{tabular}

$J$

JNK c-Jun N-terminal kinase

L

LBD Ligand binding domain

LPS Lipopolysaccharides

M

MAPK Mitogen-activated protein kinase

MEKK1 MAPK kinase 1

N

NSAID's Non-steroidal anti-inflammatory drugs

NF-IL6 Nuclear factor interleukin 6

NF-kB Nuclear factor kappa B

NK Natural killer cells

$P$

\begin{tabular}{ll}
\hline PDGF & Growth factor derived from platelets \\
PG & Prostaglandins \\
PGD2 & Prostaglandin D2 \\
PGE2 & Prostaglandin E2 \\
PGF2 & Prostaglandin F2 \\
PGG2 & Prostaglandin G2 \\
PGH2 & Prostaglandin H2 \\
PGI2 & Prostaglandin I2 \\
PI3K & Phosphoinositide 3-kinase
\end{tabular}


PKC- $\zeta \quad$ Protein kinase C-zeta

PR Progesterone receptor

PR-A Progesterone receptor-A

PR-B Progesterone recepto-B

PR-C Progesterone receptor- $\mathrm{C}$

$\mathbf{R}$

ROS Reactive oxygen species

Raf-1 Murine leukemia viral oncogene homolog 1

Ras Rat sarcoma viral oncogene

S

Scr Serum creatinine response

STAT3 Signal transducer and activator of transcription 3

$\mathbf{T}$

Th1 Thelper type 1

TNF-a Tumor necrosis factor-alpha

TP53 Tumor Protein 53

TRAIL Apoptosis-inducing ligand related to the tumor necrosis factor

TXA2 Thromboxane A2

V

VEGF Vascular endothelial growth factor 


\section{Chapter 1: Introduction}

Cancer is a worldwide disease, it was estimated that in Europe in 2008 there were 3.2 million new cancer cases and 1.7 million deaths from cancer, and breast cancer accounted for 420.850 new cases, leading to death 129.390 women (Ferlay et al. 2010). In the same year, in Portugal, it is estimated that there were 5.280 new cases and 1.520 deaths from breast cancer (Ferlay et al. 2010). This represents a matter of great concern because dead by breast cancer is the most important cause of cancer mortality in women between 40 and 50 years old (Danaei et al. 2005).

Despite being a disease more common in westernized countries, there is some variability in incidence and mortality in these countries, probably associated to different behavioral and environmental risk factors (Danaei et al. 2005; Ruddon 2007).

The etiology of breast cancer is unknown, but inflammation plays an important role in breast cancer development. The mechanisms involving the inflammatory process in breast cancer genesis are poorly understood (Lu et al. 2006).

\section{Inflammation and Carcinogenesis}

\section{Carcinogenic Risk Factors}

The most important factors associated with carcinogenic risk for breast cancer, are heredity, persistent hormonal stimulation and chronic inflammation (Henderson and Feigelson 2000; Ruddon 2007).

About $10 \%$ of the breast cancers are hereditary in origin, most of them associated with a mutation in the breast cancer type 1 (BRCA1), breast cancer type 2 (BRCA2), and tumor protein 53 (TP53) genes; therefore family history is a determinant risk factor (Polyac 2007; Schlehe and Schmutzler 2008).

Hormonal factors also stimulate breast tumor growth. Hormones are considered risk factors for breast cancer, due to the promoting effect of estrogen and progesterone in carcinogenesis (Pitot and Dragan 1991). Clinical factors related with hormonal stimulation, such as early menarche, late menopause, postmenopausal obesity, hormone replacement therapy and oral contraceptives, have been implicated as epidemiologic factors associated with breast cancer (Henderson and Feigelson 2000). In those women with history of early menarche and late menopause there are a lot of ovulatory cycles, with long and intensive exposure to estrogen 
and progesterone (Henderson and Feigelson 2000). In adipose tissue androgens, by aromatase enzymatic action, are converted into estrogen (Henderson and Feigelson 2000; Ruddon 2007). Postmenopausal obese women have increase free estrogen levels in circulation (Henderson and Feigelson 2000; Ruddon 2007). Women in hormone replacement therapy, have increased mammographic breast density, consequence of estrogenic breast stimulation, which seems to be a risk factor for breast cancer (Ross et al. 2000). In the Ross et al. study 2.500 postmenopausal women in hormone replacement therapy for every 5 years of use, the risk of breast cancer increased 10\% (Ross et al. 2000). The risk of oral contraceptives for breast cancer development is more controversial, however it should be considered when used before age of 20 (Henderson and Feigelson 2000; Ruddon 2007). Probably long and continued expositions to pill estrogen and progestin have a promoting effect on breast carcinogenesis (Henderson and Feigelson 2000). Hormonal factors have been considered as risk factors for breast cancer, due to the promoting effect of estrogen and progesterone in carcinogenesis (Pitot and Dragan 1991).

It is estimated that the pathogenesis of $15-20 \%$ human tumors is related to chronic inflammation (Karin and Greten 2005; Allavena et al. 2008). Chronic inflammation has been considered as a risk factor for breast cancer, probably, in consequence of continuous release of inflammatory mediators that impair the tissue regeneration and enhance tumor growth $\mathrm{Hu}$ et al. 2008).

\section{Inflammatory Pathway}

Inflammation is a physiological process in response to foreign agents from self (Lu et al. 2006). The first line of defense of the inflammatory response is the innate immune response at this stage there is migration of neutrophils, macrophages, mast cells, dendritic cells (DC) and natural killer cells (NK) to inflammation site (Lu et al. 2006; DeNardo and Coussens 2007). These cells have the ability to release inflammatory mediators such as interleukin 10, 12 and 23 (IL-10, IL-12, IL-23) and tumor necrosis factor-alpha (TNF-a), which may enhance the capacity of phagocytosis, neutralization or elimination of the foreign agent (DeNardo and Coussens 2007; Lin and Karin 2007). Almost simultaneously to the innate immune response, adaptive immune response occurs, where the DC present antigens to $T$ cells, leading them into inflammation site, followed by B cells, with subsequent clonal expansion and destruction or neutralization of the antigen (DeNardo and Coussens 2007). When foreign agents are completely neutralized or destroyed, the inflammatory process ceases, however, in the event of deregulation of acute inflammatory process, sets up a chronic inflammation (Lu et al. 2006; DeNardo and Coussens 2007).

Rudolf Virchow, in nineteenth century, was the first to suggest a link between chronic inflammation and cancer, noting that some irritants, when they were not eliminated, cause 
chronic inflammation and cell proliferation, and increase cancer risk (DeNardo and Coussens 2007). Currently, epidemiological studies refer that inflammation associated with cancer accounts for $15-20 \%$ of worldwide deaths, and this relationship is due to two routes, intrinsic and extrinsic pathways (Mantovani et al. 2008).

The intrinsic pathway is activated by genetic events such as activation of oncogenes by mutation, chromosomal rearrangement or amplification and inactivation of tumor suppressor genes events that promote cellular alterations with subsequent release of inflammatory mediators (Mantovani et al. 2008). The extrinsic pathway is triggered by infectious or inflammatory events that increase the risk of developing cancer in certain anatomic sites (Mantovani et al. 2008).

The activation mechanisms of the two pathways are different, however, converge on activation of transcription factors like the nuclear factor kappa B (NF-kB), signal transducer and activator of transcription 3 (STAT3) and hypoxia inducible factor 1 alpha (HIF1-a) (Mantovani et al. 2008). These factors recruit and activate inflammatory cells and coordinate the production of inflammatory mediators such as cytokines, which activate transcription factors in inflammatory cells (Mantovani et al. 2008). Production of inflammatory mediators by transcription factors, results in an inflammatory micro-environment (see figure 1), characterized by tissue damage and malignant growth (Lu et al. 2006; Mantovani et al. 2008).

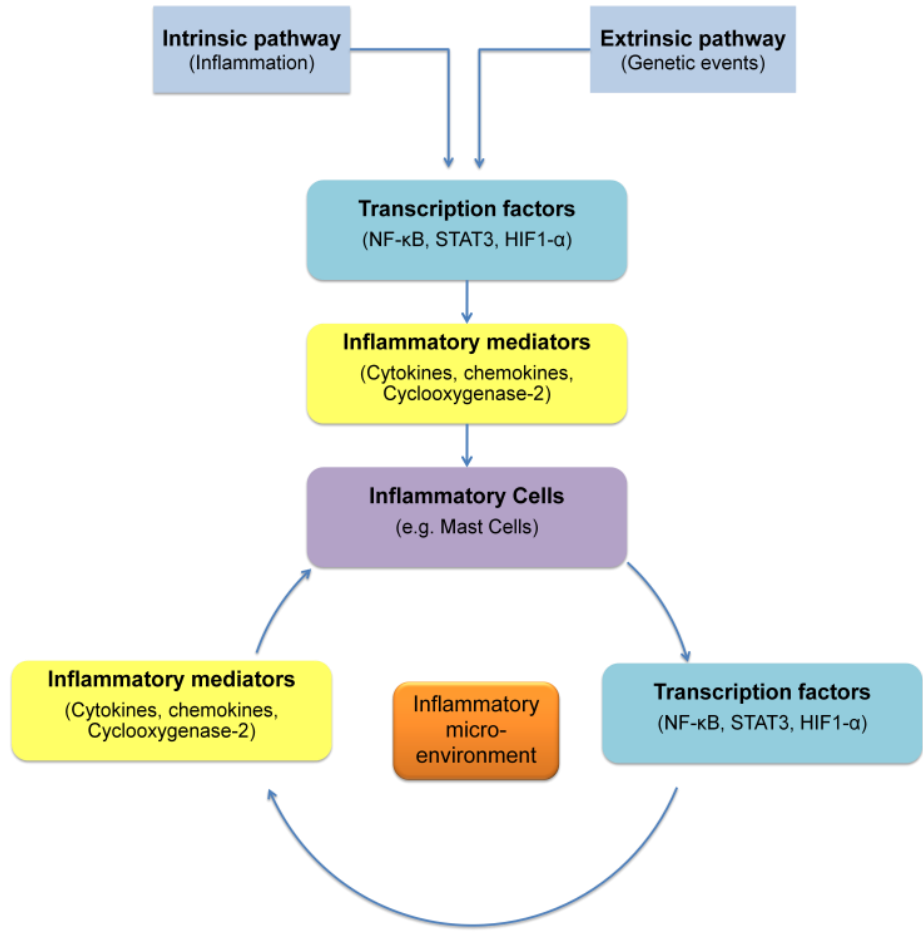

Figure 1: Intrinsic pathway is activated by genetic events, whereas extrinsic pathway is activated by inflammatory or infectious events, both culminate on NF-kB activation, and other transcription factors, that recruit and active inflammatory cells through inflammation mediators as cytokines, more transcription factors are activated, resulting in an inflammatory micro-environment. 
The microenvironment of chronic inflammation is dominated by macrophages, which are divided into two classes $M 1$ and $M 2$, having, respectively, anti-inflammatory or protumorigenic properties and may be involved in carcinogenesis, tumor invasion and metastasis (Karin and Greten 2005; Lu et al. 2006; Mantovani et al. 2008).

M1 class when exposed to interferon-gamma (IFN- $\gamma$ ) results in IL-12, IL-23 and IFN- $\gamma$ synthesis (see figure 2) (Karin and Greten 2005).

IL-12 confers host resistance to tumor, promoting T helper type 1 (Th1) adaptive immunity, cytolytic T lymphocyte (CTL) response and induction of IFN-Y (Lin and Karin 2007; Grivennikov et al. 2010).

IL-23 belongs to the IL-12 super-family, however, may have an anti or pro-tumorigenic effect (Lin and Karin 2007). The anti-tumorigenic effect increased proliferation of memory $\mathrm{T}$ cells, IFN-Y and IL-12 (Lin and Karin 2007).

IFN- $\gamma$ has a toxic effect on cancer cells and angiogenic activity, induces apoptosis-inducing ligand related to the tumor necrosis factor (TRAIL) production by monocytes, NK and DC cells (Karin and Greten 2005; Lin and Karin 2007).

TRAIL induces apoptosis in various tumor cells, however, requires the inhibition of NF-KB or neutralization of the activator of NF-KB (TNF-a), if this inhibition does not occur, the tumors become resistant to the TRAIL cytotoxicity (Lin and Karin 2007).

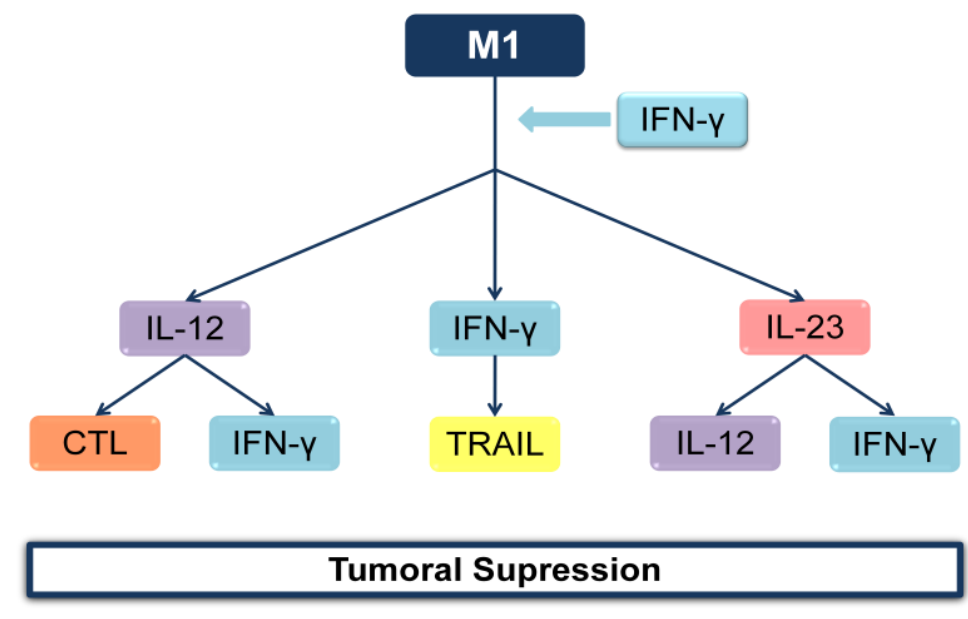

Figure 2: $M 1$ class when exposed to IFN- $\gamma$ induces IL-12, IL-23 and IFN- $\gamma$, which recruit more inflammatory mediators that participate in tumor suppression, by events such as phagocytosis and apoptosis.

Class M2 when exposed to interleukine 4 (IL-4) originates interleukine 1 (IL-1), interleukine 6 (IL-6), IL-10 and TNF-a formation (see figure 3) (Balkwill et al. 2005; Karin and Greten 2005). 
Macrophages produce IL-1 that is abundant in tumorigenic sites (Lin and Karin 2007; Allavena et al. 2008). This cytokine expressed constitutively NF-kB, which up-regulates cyclooxygenase-2 (COX-2) expression and induces HIF1a expression, resulting in vascular endothelial growth factor (VEGF) production by stromal cells, increasing invasive and metastatic ability of tumor cells (Balkwill et al. 2005; Karin and Greten 2005; Lu et al. 2006).

IL-6 is also an inflammatory mediator and an anti-apoptic factor and is considered a key factor in tumor growth (Lin and Karin 2007; Allavena et al. 2008). IL-6 levels increases with increasing age due to loss of inhibitory sex hormones, resulting in inhibition of DC maturation; cytokine signal transduction of this cytokine is performed by STAT3 (Balkwill et al. 2005; Lin and Karin 2007).

IL-10 is a cytokine with pro and anti-tumorigenic effects (Lin and Karin 2007). Its antitumorigenic effect is TNF- $a$ and IL-6 inhibition, inhibiting NF-kB activation, having antiangiogenic properties (Lin and Karin 2007). However, his pro-tumorigenic effect occurs by STAT3 activation, blocking DC maturation, repression of $M 1$ polarization and suppression of cytotoxic activity of macrophages (DeNardo and Coussens 2007; Lin and Karin 2007).

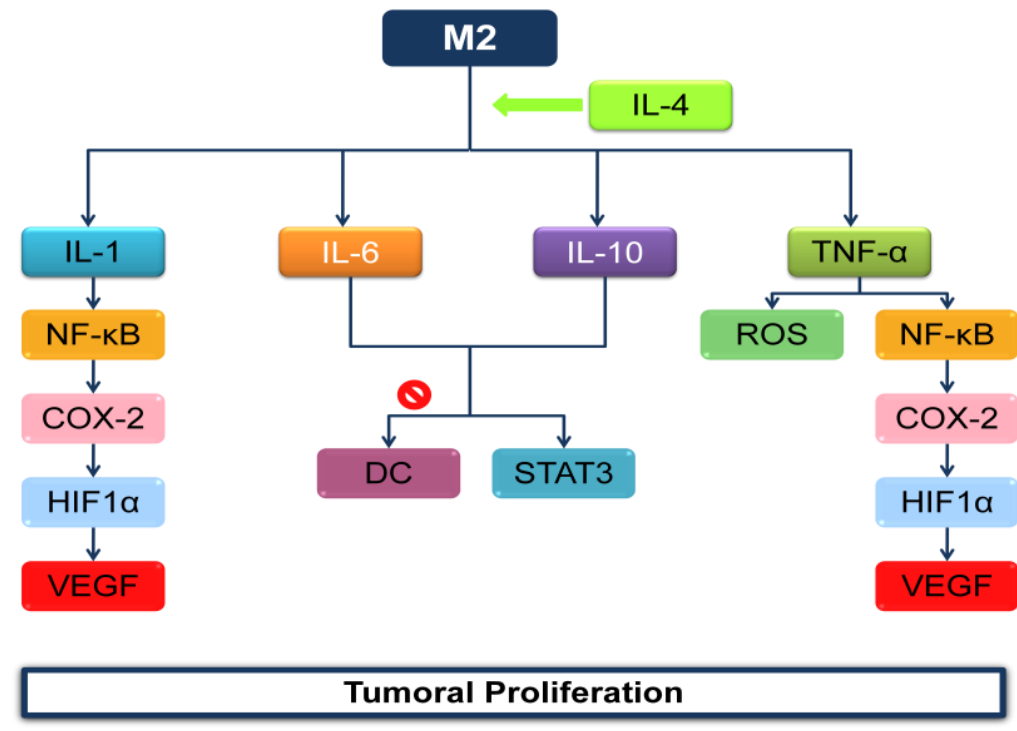

Figure 3: M2 class when exposed to IL-4 induces IL-1, IL-6, IL-10 and TNF-a, which recruits more inflammatory mediators and transcription factors. COX-2 is expressed as a result of this mast cells class and together with other inflammatory mediators confers tumor proliferation, inhibiting apoptosis and stimulating angiogenesis.

TNF-a is a pro-inflammatory cytokine, eradicates anti-tumor immunity and accelerates progression, angiogenesis and metastasis of various cancers (Lin and Karin 2007; Schetter et al. 2010). TNF-a activates NF-kB, which by COX-2 induction activates HIF1a, which induces angiogenic factors, contributing for proliferation and cancer cells survival (Karin and Greten 2005; Lu et al. 2006; Allavena et al. 2008; Schetter et al. 2010), and produces reactive 
oxygen species (ROS) which cause deoxyribonucleic acid (DNA) damage and inhibit DNA repair (Lu et al. 2006; Lin and Karin 2007).

Tumor development depends on the collective balance between cytokines, which can be pro or anti-inflammatory (Schetter et al. 2010). When anti-tumor activity overlaps immunosuppressive activity, there is activation of transcription factors that enhance invasion and metastasis of tumor cells (Lin and Karin 2007).

One of the transcription factors that potentiate tumor development is the HIF1- $\alpha$, which promotes chronic inflammation, tumor growth and angiogenesis via the transcription of VEGF (Lu et al. 2006).

STAT3 promotes inflammatory microenvironment development, proliferation, apoptosis resistance and immune tolerance (Lu et al. 2006; Grivennikov et al. 2010). It is constitutively activated in inflammatory cells and tumor cells by pro-inflammatory cytokines, lying in different types of cancer (Lu et al. 2006).

NF-KB regulates several inflammatory molecules, phagocytosis and suppresses apoptosis leading to tumor growth and proliferation (Lu et al. 2006). NF-KB is considered the key factor between inflammation, promotion and tumor progression, because it becomes active after an inflammatory stimulus (Karin and Greten 2005; Schetter et al. 2010). This transcription factor acts binding to kappa B inhibitor (IKB) that is found in the cytoplasm, the IKB is phosphorylated and enters in proteasomal degradation after an inflammatory stimulus, NF-kB is released and enters in the nucleus where it activates COX-2 transcription, which is overexpressed in various types of cancer (Schetter et al. 2010).

\section{Cyclooxygenase}

The cyclooxygenase (COX) or prostaglandin $\mathrm{H} 2$ synthase (HSPG) is an enzyme that catalyzes the prostaglandins (PG) production from arachidonic acid (AA) (Singh-Ranger et al. 2008). Exists in two isoforms, cyclooxygenase-1 (COX-1) and COX-2, the first is constitutively expressed in different tissues including platelets, gastric mucosa, kidney, being responsible for maintaining homeostasis in these tissues (Isakson 2003; Schetter et al. 2010). The second isoform was discovered in 1992, is expressed in most tissues, is the induced form in response to growth factors, tumor promoters, hormones and cytokine (Isakson 2003; Singh-Ranger et al. 2008).

The COX-2 expression and subsequent increase of transcription factors such as HIF1- $\alpha$ and prostaglandins play a key role in mediating the inflammatory response, may affect cell 
proliferation, DNA mutation rates, angiogenesis and metastasis, and is a potential therapeutic target in treating breast cancer (Isakson 2003; Singh-Ranger et al. 2008; Schetter et al. 2010).

COX can be inhibited by non-steroidal anti-inflammatory drugs (NSAID's) or by selective inhibition of COX-2 such as celecoxib (Schetter et al. 2010). Continued use of these drugs has been associated with reduction of certain cancers such as breast cancer, confirming the relationship between COX and the inflammatory process; however, these drugs may cause adverse effects such as renal and cardiovascular toxicity (Schetter et al. 2010).

\section{Cyclooxygenase-2 Up-regulation Mechanisms}

There is evidence that several mechanisms contribute to the COX-2 overexpression in tumor tissues (Howe et al. 2001).

COX-2 human promoter contains multiple binding sites for transcription factors that respond to different stimuli such as cyclic adenosine monophosphate (CAMP), cAMP response element (CRE), nuclear factor interleukin 6 (NF-IL6) and NF-kB (Howe et al. 2001).

These factors induce COX-2 expression in response to stimuli like lipopolysaccharides (LPS), growth factor derived from platelets (PDGF), interleukin 1 beta (IL-1B) and TNF- $\alpha$ (see figure 4) (Howe et al. 2001; Davies et al. 2002; Dannenberg and Howe 2003; Bassères and Baldwin 2006).

PDGF induces COX-2 by activation of rat sarcoma viral oncogene/murine leukemia viral oncogene homolog 1/extracellular signal-regulated protein kinase (Ras/Raf-1/ERK) and rat sarcoma viral oncogene/mitogen-activated protein kinase kinase 1/c-Jun $\mathrm{N}$-terminal kinase (Ras/MEKK1/JNK) signal transduction pathways and is predominantly mediated by the CRE (Howe et al. 2001).

The inflammatory mediators IL-1B and TNF- $\alpha$ degrade IKB via phosphoinositide 3-kinase/ protein kinase $B$ (PI3K/Akt), NF-KB is released and induces COX-2 transcription (Bassères and Baldwin 2006).

COX-2 induction by LPS occurs via mitogen-activated protein kinase (MAPK) and via protein kinase C-zeta (PKC- $\zeta$ ) (Davies et al. 2002). MAPK can also be activated by ceramide, which activates JNK; leading to COX-2 and AA increased expression, which results in PG increased production (Howe et al. 2001; Davies et al. 2002). 


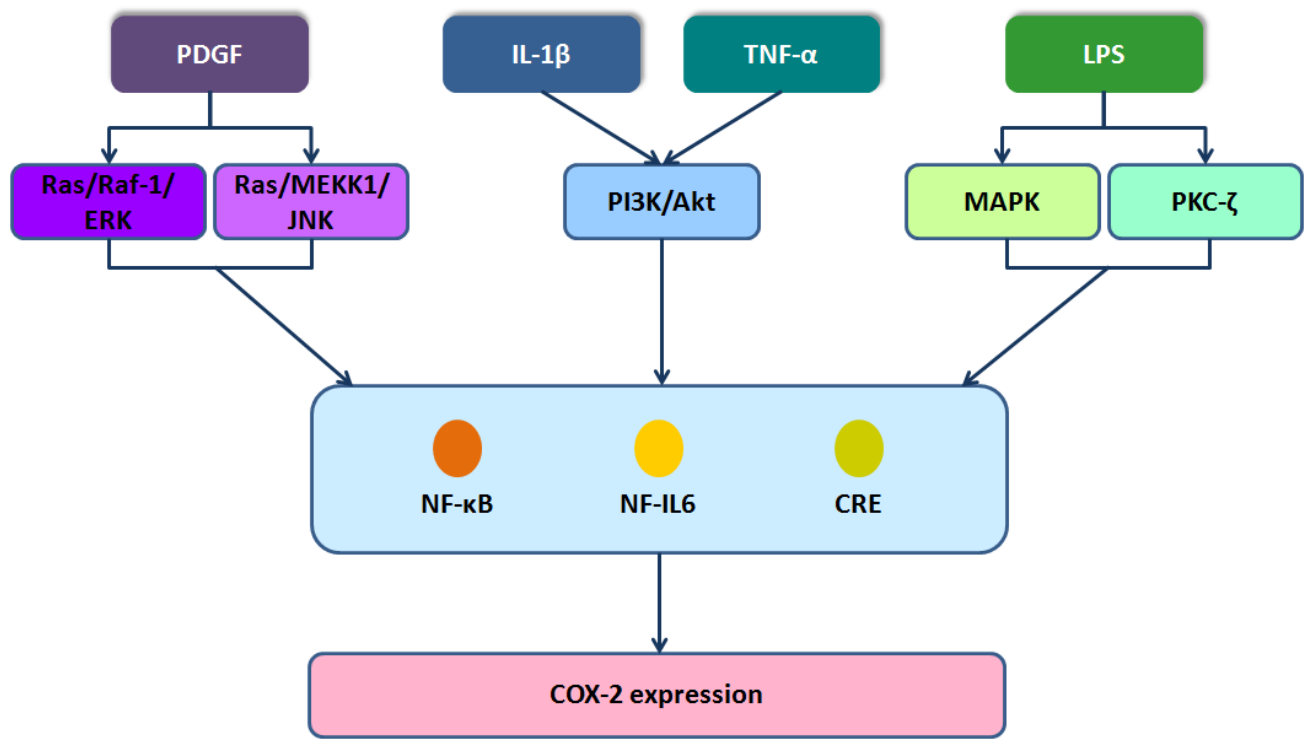

Figure 4: COX-2 is up-regulated by PDGF that induces COX-2 via Ras/Raf-1/ERK and Ras/MEKK1/JNK, by $\mathrm{IL}-1 \mathrm{~B}$ and TNF- $\alpha$ via PI3K/Akt and NF-KB and by LPS via MAPK and PKC- $\zeta$, these signal transduction pathways bind to COX-2 human promoter, inducing its over-expression.

\section{Prostaglandins Synthesis}

AA released from phospholipids membrane by phospholipase A2 action is metabolized by COX action (Singh-Ranger et al. 2008). This process occurs in two steps, in first COX inserts molecular oxygen in AA, prostaglandin $\mathrm{G} 2$ is produced (PGG2) and is converted in prostaglandin $\mathrm{H} 2$ ( $\mathrm{PGH} 2$ ) by COX peroxidase activity (Howe et al. 2001). PGH2 by specific prostanoid isomerases action is converted in prostaglandin E2, F2, D2, 12 (PGE2, PGF2, PGD2, PGI2) and thromboxane A2 (TXA2) (see figure 5) (Howe et al. 2001; Gately and Kerbel 2003).

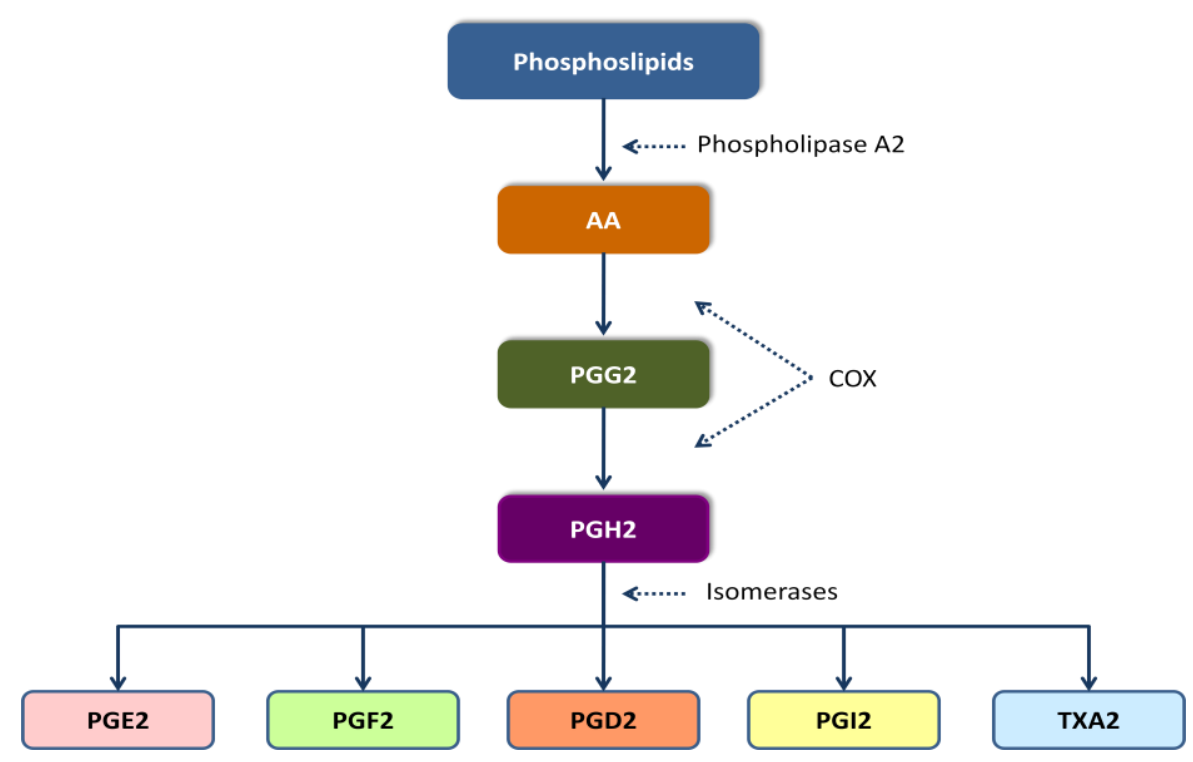

Figure 5: Phospholipase A2 synthesizes AA from phospholipids. AA is converted in PGH2 through COX-2, in turn PGH2 is converted in PG by specific isomerases. 
Prostaglandins presence and levels, especially PGE2, in human tumor tissues have been associated with the aromatase and human epidermal growth factor receptor 2 (HER-2) expression with consequent poor prognosis (Davies et al. 2002; Mendelson and Hardy 2006).

\section{Epidermal Growth Factor Receptor 2 Synthesis}

HER-2 is a transmembrane receptor protein that belongs to epidermal growth factor receptor family with over-expression occurring in approximately 30\% of breast tumors (Benoit et al. 2004).

HER-2 induces NF-KB and activates COX-2 synthesis via Ras/MAPK, resulting in prostaglandins synthesis, primarily PGE2 (Benoit et al. 2004; Bassères and Baldwin 2006).

Benoit et al. found that COX-2 expression is related to HER-2 expression via PGE2, and PGE2 inhibition by celecoxib resulted in HER-2 reduced expression (see figure 6) in breast tumors (Benoit et al. 2004).

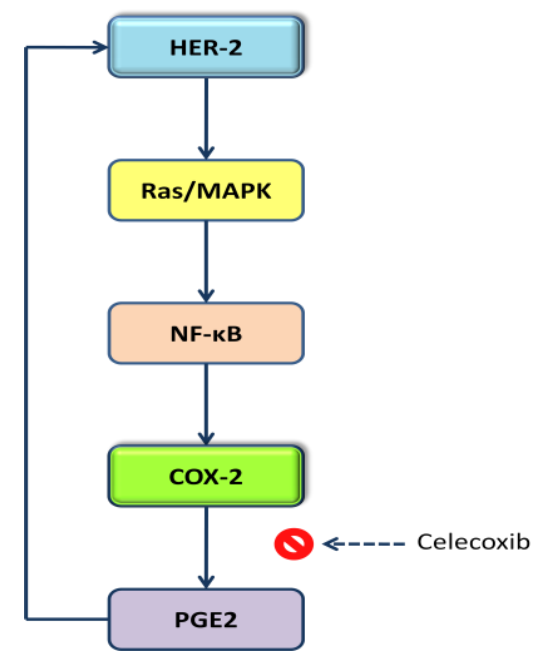

Figure 6: HER-2 induces COX-2 up-regulation via Ras/MAPK and NF-kB, COX-2 is over-expressed and converts AA in PG. Synthesized PGE2 stimulates HER-2, suggesting a positive feedback between COX-2 and HER-2. Use of Celecoxib (COX-2 inhibitor) has proof this theory, because it inhibits PGE2 synthesis and as result HER-2 levels are diminished.

COX-2 increased expression by HER-2, establishes a relationship between HER-2 and aromatase, both present in breast tumors with high proliferation rate (Mendelson and Hardy 2006; Subbaramaiah et al. 2006). 


\section{Aromatase Synthesis}

PGE2 stimulates CAMP signaling cascade, PKA and CRE that increase cytochrome protein 450, subfamily XIX (CYP19) gene transcription, with consequent aromatase activation (see figure 7) (Mendelson and Hardy 2006; Subbaramaiah et al. 2006). This enzyme is responsible for estrogen synthesis, Subbaramaiah et al. concluded that estrogen synthesis via the PGE2 is a consequence of COX-2 induction by the HER-2 (Mendelson and Hardy 2006; Subbaramaiah et al. 2006).

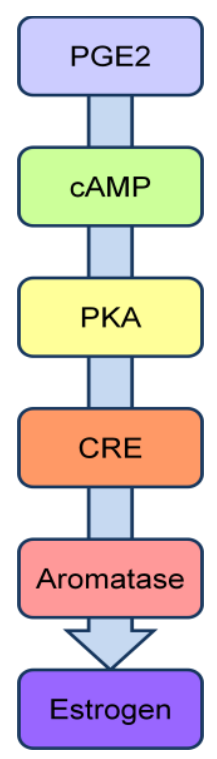

Figure 7: PGE2 induces estrogen synthesis. PGE2 via CAMP, PKA and CRE activates aromatase resulting in estrogen synthesis.

Thomas et al. found that synthesized estrogen also had positive feedback on COX-2 expression (Thomas et al. 2008). Estrogen binds to its receptor and undergoes translocation to the nucleus; this interaction activates serum creatinine response $(\mathrm{Scr})$, which stimulates metalloproteins cascade, allowing epidermal growth factor (EGF) release from heparin and its binding to HER-2, which activates ERK (Thomas et al. 2008). Phospholipase A2 is a ERK substrate and its active form releases phospholipids from cell membranes, AA is formed, with consequent synthesis of PGE2 (see figure 8) (Thomas et al. 2008). 


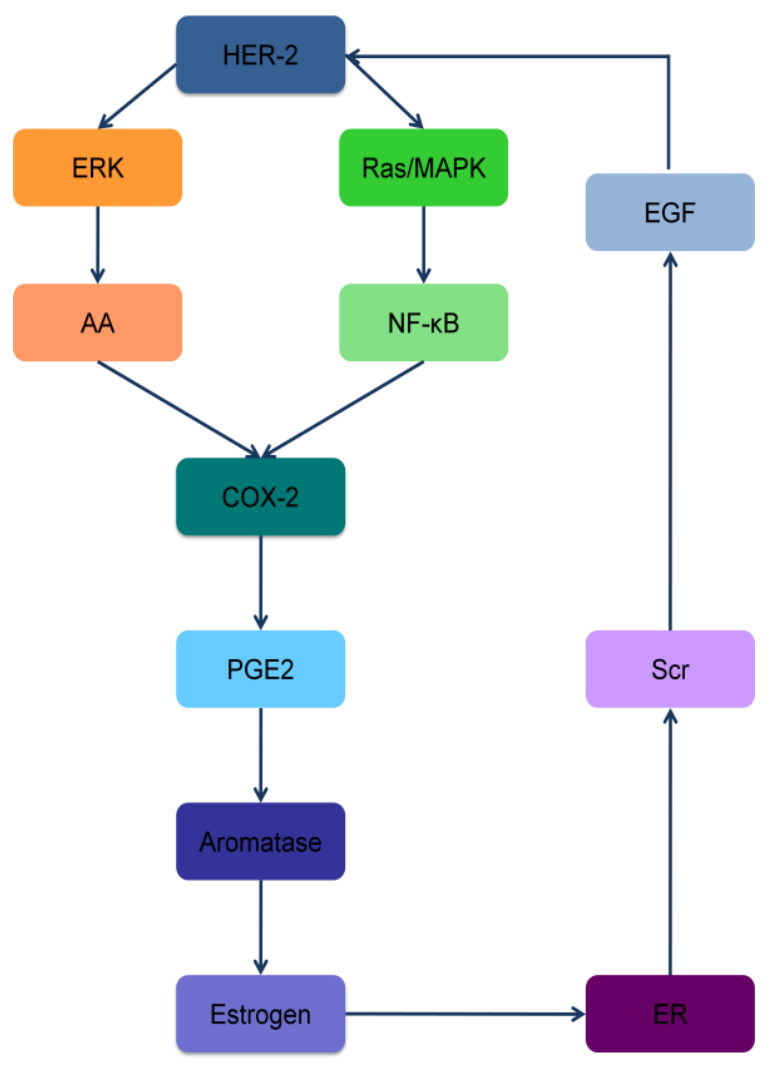

Figure 8: COX-2 synthesizes PGE2 which via CAMP induces CYP19 expression, resulting in estrogen synthesis by aromatase. Estrogen acts through its receptor and undergoes translocation to the nucleus where activates Scr, allowing EGF binding to its receptor. HER-2 acts through NF-KB activating COX-2 expression, and through ERK resulting in AA formation. More PGE2 is produced and as consequence more estrogen is synthesized by aromatase, suggesting a feedback between estrogen and HER-2.

Estrogen binding to its receptor increases inflammatory process and is involved in pathophysiology of various cancers, including breast cancer (Mendelson and Hardy 2006; Subbaramaiah et al. 2006).

\section{Steroid Hormone Receptors}

Approximately $75 \%$ of breast cancers express estrogen receptors (ER) (Cui et al. 2005). ER is a nuclear transcription regulator that can bind to transcription factors, proteins and estrogen (Cui et al. 2005; Mendelson and Hardy 2006).

There are two isoforms of this receptor that are expressed in mammary gland, estrogen receptors alpha and beta (ERa and ERB), ERa over-expression is critical to breast cancer development (Cui et al. 2005).

It has long been thought that ER induced progesterone receptor (PR) and that serves as an indicator of ER functional capacity; new studies indicate that PR is an independent predictor risk factor and have protective actions which antagonize inflammatory response pathway (Mendelson and Hardy 2006). 
PR exists in three isoforms, progesterone receptor-A (PR-A) (94kDa), progesterone receptor-B (PR-B) $(110 \mathrm{kDa})$ and progesterone receptor-C (PR-C) (60kDa) (Abdel-Hafiz et al. 2009). PR are proteins with several domains, a DNA binding domain (DBD), $\mathrm{N}$-terminally that activates proximal activation function 1 (AF-1) common to PR-A and PR-B, and a C-terminally that upstream ligand binding domain (LBD) has a nuclear localization region with activation function 2 (AF-2) (Mendelson and Hardy 2006; Abdel-Hafiz et al. 2009).

PR-A and PR-B are equimolar in most tissues, but in breast cancer this balance does not exist, PR-A can block all three PR-B transcriptional activation domains, acting as PR repressor in breast cancer (Mendelson and Hardy 2006).

PR-C isoform is augmented in cancerous breast cells, binds to PR-B reducing its capacity to interact with progesterone response elements in progesterone-responsive genes (Mendelson and Hardy 2006).

Mendelson et al. concludes that NF-KB increased activation, results in PR-C over-expression that together with PR-A and PR-B ablation results in COX-2, HER-2 and aromatase overexpression, suggesting a protective role of RP in breast cells (Mendelson and Hardy 2006).

\section{Progesterone Receptor and Breast Cells}

In breast cells PR directly interacts with NF-kB to block its binding to DNA, or inhibits NF-kB activation and translocation to the nucleus via IKBa (Mendelson and Hardy 2006). NF-KB has a major role in COX-2 over-expression, which in turn up-regulate expression of the genes encoding aromatase and HER-2 via PGE2, resulting in estrogen up-regulation (Mendelson and Hardy 2006).

PR impairs NF-KB transactivation of COX-2 via induction of $1 K B a$, these findings suggest that NF-KB inhibition by PR, results in estrogen lower levels and PR serves a crucial role in blocking breast tumor formation and progression (see figure 9) (Mendelson and Hardy 2006; Hardy et al. 2008). 


\section{Chronic inflammation}

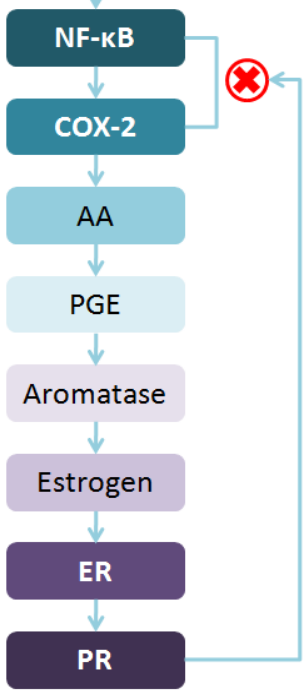

Figure 9: COX-2 is expressed in chronic inflammation, converting AA into PGE, leading to aromatase increase with subsequent increase of ER and PR. PR through NF-KB inhibition results in COX-2 lower expression.

Another suggestion of $\mathrm{PR}$ protective role is $\mathrm{ER}^{+} / \mathrm{PR}^{-}$receptor tumor subtype that can amplify HER-2 expression, which results in a worse overall survival (Cui et al. 2005). There are four receptor tumor subtypes: $\mathrm{ER}^{+} / \mathrm{PR}^{+}, \mathrm{ER}^{+} / \mathrm{PR}^{-}, \mathrm{ER}^{-} / \mathrm{PR}^{+}$and $\mathrm{ER} / \mathrm{PR}$, that differs with age, hormone use and menopause (Cui et al. 2005). ER $/ \mathrm{PR}^{-}$is the most aggressive receptor tumor subtype, it has high proliferation rates and has higher recurrence than $\mathrm{ER}^{+} / \mathrm{PR}^{+}$, this findings also suggests that PR has a protective role in breast cancer (Arpino et al. 2005).

Based on these studies, which indicate that PR might have a protective role in breast cancer, we speculate that tumors with positive COX-2 expression and positive PR expression had an overall better prognosis than tumors with positive COX-2 expression and negative PR expression. It was performed an immunohistochemical study to determine a possible relation between COX-2 and PR expression, correlating them with clinicopathologic factors (age, tumor size, histologic grade and axillary node metastasis), which are known to be classical prognostic factors in breast cancer. 


\section{Chapter 2: Materials and Methods}

\section{Patients Selection}

Child and Women department of Cova da Beira Medical Center has initiated its Gynecological Oncology activity in 2005 and since then has given assistance to several women with breast cancer.

In 2007 the department had a restructuration and started to work with the current anatomic pathology laboratory, for these reason only clinical cases from 2007 to 2009 were selected. For immunohistochemical study, it was selected 31 clinical cases that meet the follow criteria:

1. Histological invasive ductal carcinoma confirmed by an independent pathologist

2. Tumor with $10 \mathrm{~mm}$ or more in longest diameter (in order to material preservation for further studies)

3. Submitted to radical surgery with axilary assessment

4. No pregnant woman

5. No primary chemotherapy or hormonotherapy

6. No documented distant metastasis

\section{Immunostaining}

\section{Sample Pre-treatment}

It was selected representative pathologic material from paraffin blocks. From each selected paraffin block were obtained three $3 \mu \mathrm{m}$ sections: one slide was for hematoxylin-eosin staining and the remaining two slides were for COX-2 and PR immunostaining.

\section{Cyclooxygenase- 2 and Progesterone Receptor Immunostaining}

In histological sections for immunostaining, a dewaxing was performed during 10 minutes with xylene, followed by rehydration in decreasing ethanol grades (absolute, 95\% and 70\%) and water. To proceed with the antigen retrieval, slides were put into pressure cooker and citrate buffer $0.01 \mathrm{M}$ for 6 minutes at pH 6 and washed with water and buffer solution (K5006, ChemMat ${ }^{\text {MM }}$, Dako).

The slides were then incubated with the primary antibody, for COX-2 staining was used clone SP21, rabbit monoclonal antibody (MC-16-240r, CellMarque ${ }^{T M}$ ) at 1:10 dilution; for PR staining were used clone 16 and clone SAN27 (NCL-L-PGR-AB, Novocastra ${ }^{\mathrm{TM}}$ ) at 1:100 dilution, in both 
cases the diluent used was S2022 (Dako Real) and incubation with the primary anti-body was made for 25 minutes at room temperature, then washed with buffer solution (K5006, ChemMat ${ }^{\mathrm{T}}$, Dako).

Incubation with biotinylated secondary antibody was made for 25 minutes, using the bottle A from K5001 kit (Dako Real ${ }^{\mathrm{T}}$ ), followed by washing with buffer solution (K5006, ChemMat ${ }^{\mathrm{T}}$, Dako). The next step was to block endogenous peroxidase using bloking-Peroxidase solution (S2023, Dako Real ${ }^{\mathrm{TM}}$ ) for 7 minutes and 30 seconds, followed by washing with buffer solution (K5006, ChemMat ${ }^{\mathrm{T}}$, Dako).

After these procedures, it was added streptavidin conjugated horseradish peroxidase (HRP) (bottle B, K5001, Dako Real), for 25 minutes followed by washing with buffer solution (K5006, ChemMat ${ }^{\mathrm{m}}$, Dako), chromogen was added (Dako Real DAB + chromogen, bottle C + HRP substrate buffer bottle D, K5001, Dako Real) at a 20:1000 dilution for 15 minutes with washes at every 5 minutes, this was followed by washing with a buffer solution (K5006, ChemMat ${ }^{\mathrm{T}}$, Dako). The counterstaining was done with Mayer's hematoxylin for 1 minutes and washed with a buffer solution (K5006, ChemMat ${ }^{\mathrm{T}}$, Dako), dehydrated in increasing ethanol grades $(75 \%$, $90 \%$, absolute) and xylene. Slides were preserved in synthetic mounting medium, and were analyzed with an optical microscope (x400), using 50 fields for slide.

For COX-2 was considered cytoplasmatic immunostaining and to PR was recorded nuclear immunostaining.

The intensity of immunostaining was recorded as: negative $(-)$, moderate $(+)$ or high $(++)$.

Positivity of immunostaining was recorded as percentage of the cells that stained. It was counted all cells in an optical high power field considered representative of all slide, in a minimum of 500 cells. For statically analysis we considered expression in less than $25 \%$ of the cell as a negative result; expression from 25 to $50 \%$ as a light expression; from 50 to $75 \%$ as moderate expression and 75 to $100 \%$ as a high expression. All cases with positive expression had a moderate or high intensity.

For comparative statistical analysis we considered as positive immunostaining cases with light, moderate or high expression. 


\section{Statistical Analysis}

Was performed a comparative study between patients clinical factors (age, tumor size, differentiation grade and ganglion metastasis) and COX-2 and PR expression.

Statistical analysis was performed using SPSS, version 17. Mann-Whitney and Chi-Squared tests were used for the analysis, considering a statistical significance when P-value was $<0.05$. 


\section{Chapter 3: Results Analysis}

\section{Descriptive Statistical Analysis}

The analyzed clinical cases were between the year 2007 and 2009 and the age of patients varied from 39 to 91 years old. Most of the tumors expressed COX-2 (64.52\%) and $45.16 \%$ of the tumors expressed PR. It was also taking into account the differentiation grade and axillary node metastasis, and we verified that twenty four of tumors had a high (G2 or G3) differentiation grade and only $29.03 \%$ of women had axillary node metastasis (see table 1 ).

Table 1: Patient characteristics: Year, Age, COX-2 expression, PR expression, Tumor Size, Differentiation Grade and Axillary Node Metastasis.

\begin{tabular}{|c|c|c|}
\hline Characteristics & N. ${ }^{\circ}$ of Patients & (\%) \\
\hline \multicolumn{3}{|l|}{ Year: } \\
\hline 2007 & 13 & $41.94 \%$ \\
\hline 2008 & 15 & $48.39 \%$ \\
\hline 2009 & 6 & $19.35 \%$ \\
\hline \multicolumn{3}{|l|}{ Age: } \\
\hline$<40$ & 2 & $6.45 \%$ \\
\hline$\geq 40<50$ & 2 & $6.45 \%$ \\
\hline$\geq 50<60$ & 3 & $9.68 \%$ \\
\hline$\geq 60<70$ & 6 & $19.35 \%$ \\
\hline$\geq 70<80$ & 9 & $29.03 \%$ \\
\hline$\geq 80<90$ & 8 & $25.81 \%$ \\
\hline$\geq 90$ & 1 & $3.23 \%$ \\
\hline \multicolumn{3}{|l|}{ COX-2 staining: } \\
\hline Negative & 11 & $35.48 \%$ \\
\hline Moderate & 18 & $58.06 \%$ \\
\hline High & 2 & $6.45 \%$ \\
\hline \multicolumn{3}{|l|}{ COX-2 expression: } \\
\hline $0-25 \%$ & 11 & $35.48 \%$ \\
\hline $25 \%-50 \%$ & 14 & $45.16 \%$ \\
\hline $50 \%-75 \%$ & 5 & $16.13 \%$ \\
\hline $75 \%-100 \%$ & 1 & $3.23 \%$ \\
\hline \multicolumn{3}{|l|}{ PR staining: } \\
\hline Negative & 17 & $54.84 \%$ \\
\hline Moderate & 10 & $32.26 \%$ \\
\hline High & 4 & $12.90 \%$ \\
\hline \multicolumn{3}{|l|}{ PR expression: } \\
\hline $0-25 \%$ & 17 & $54.84 \%$ \\
\hline $25 \%-50 \%$ & 5 & $16.13 \%$ \\
\hline $50 \%-75 \%$ & 6 & $19.35 \%$ \\
\hline $75 \%-100 \%$ & 3 & $9.68 \%$ \\
\hline \multicolumn{3}{|l|}{ Tumor size $(\mathrm{mm})$ : } \\
\hline$<20$ & 10 & $32.26 \%$ \\
\hline$\geq 20<50$ & 15 & $48.39 \%$ \\
\hline$\geq 50$ & 6 & $19.35 \%$ \\
\hline \multicolumn{3}{|l|}{ Differentiation grade: } \\
\hline $\mathrm{G} 1$ & 7 & $22.58 \%$ \\
\hline G2 & 16 & $51.61 \%$ \\
\hline G3 & 8 & $25.81 \%$ \\
\hline \multicolumn{3}{|c|}{ Axillary node metastasis: } \\
\hline Absent & 22 & $70.97 \%$ \\
\hline Present & 9 & $29.03 \%$ \\
\hline
\end{tabular}




\section{Immunohistochemestry Analysis}

\section{Cyclooxygenase-2 Immunoreactivity}

COX-2 expression was considered positive by semiquantitative scoring in 20 of 31 cases studied $(64.52 \%)$, all 20 cases had at least $50 \%$ or more of COX-2 expression and all cases had a moderate or strong staining intensity. Immunostaining intensity was considered negative in 11 cases, moderate in 18 cases and strong in 2 cases (see annex 1). In figure 10 it can be seen a moderate immunostaining with moderate expression.

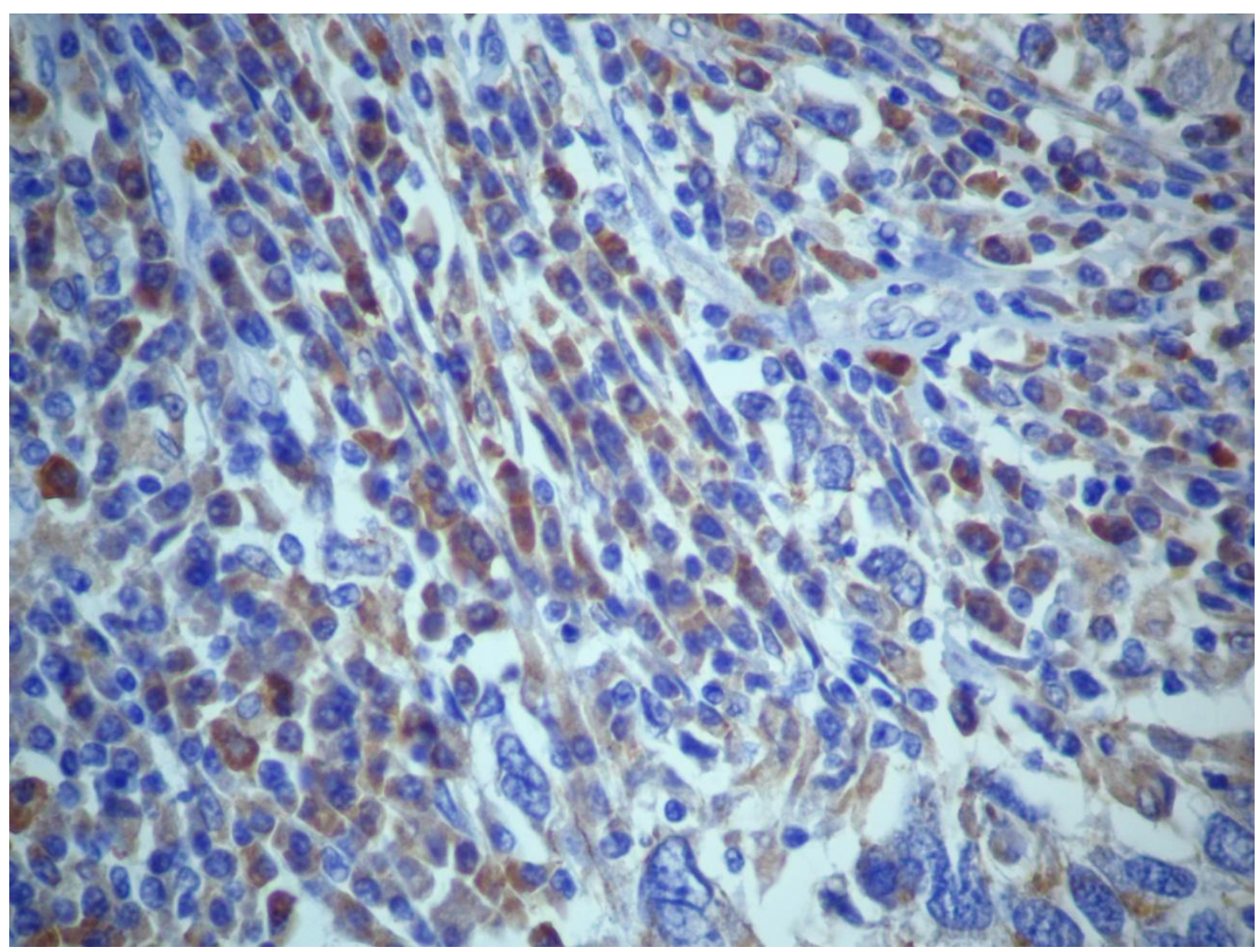

Figure 10: Immunohistochemical localization of COX-2 in ductal carcinoma (400 x magnifications). There is cytoplasmatic staining, with COX-2 light expression.

\section{Progesterone Receptor Immunoreactivity}

PR expression was detected by semiquantitative scoring in 14 of 31 cases in study $(45.16 \%)$, all 14 cases had at least $50 \%$ of PR expression and all cases had a moderate or strong staining intensity. Immunostaining intensity was negative in 17 cases, moderate in 10 cases and strong in 4 cases. In figure 11 it can be seen a strong immunostaing for PR with strong expression. 


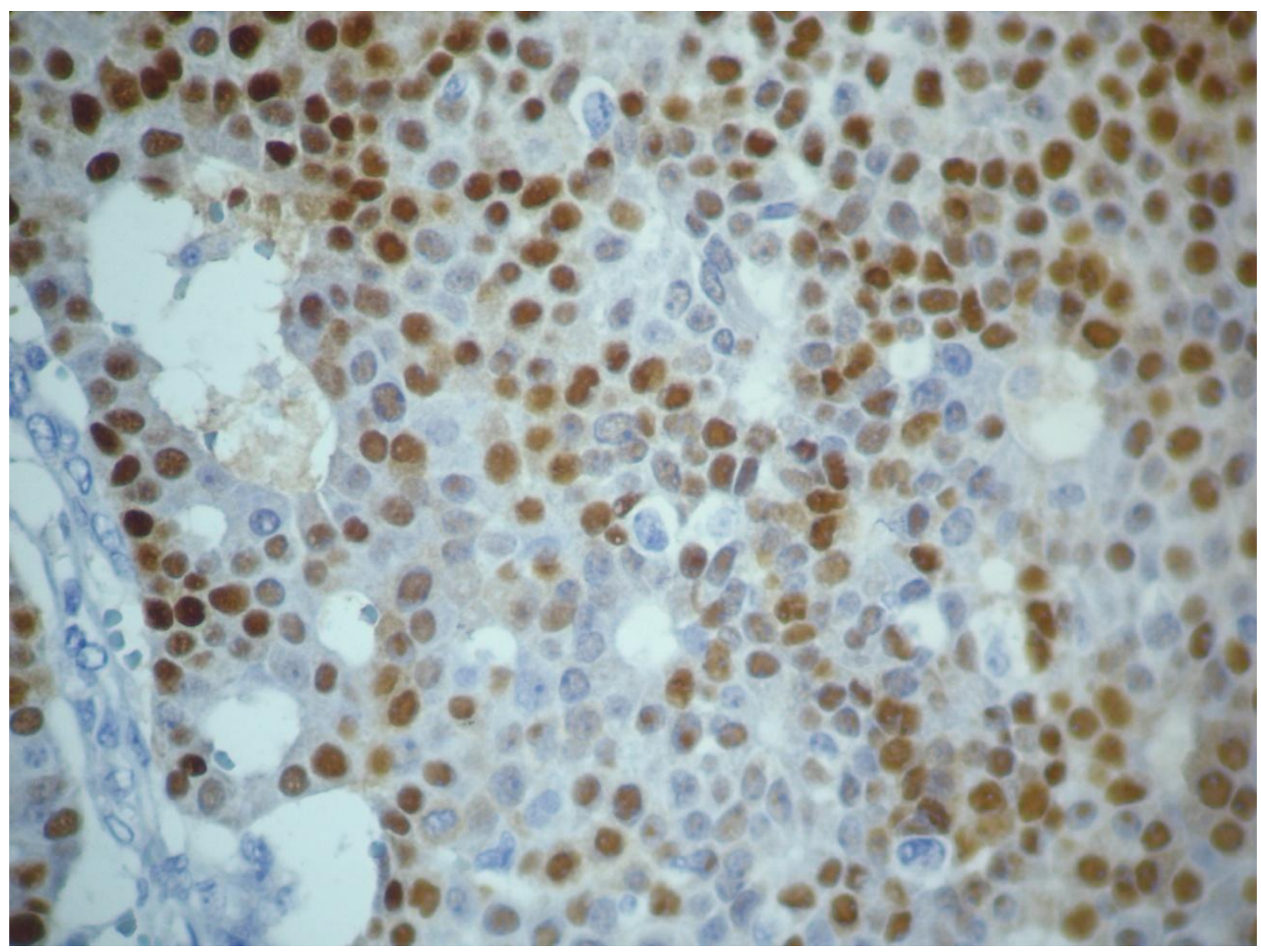

Figure 11: Immunohistochemical localization of PR in ductal carcinoma (400x magnification). There is nuclear strong staining, with PR high expression.

\section{Comparative Statistical analysis}

\section{Correlation between Clinicopathologic Factors and Cyclooxygenase-2 Expression}

As described previously, $20(64.52 \%)$ cases in study were positive for COX-2 expression and $35.48 \%$ were negative.

When COX-2 expression was correlated with age, it was verified that positive COX-2 expression group is more heterogeneous, have a higher standard deviation (16.027 years) than negative cases (8.251 years) (see annex 2).

Minimum age and maximum age are respectively 39 and 87 years old for positive COX-2 expression group, and 59 and 91 years, for negative COX-2 expression group. Breast cancers positive for COX-2 expression also have a non-statistical significant and lower mean $(65.65$ years) than breast cancers negative for COX-2 expression (75.45 years). Positive cases for COX-2 expression seem to appear in earlier ages than negative cases (see figure 12). 
However, there is no statistic significance $(p=0.121)$ when COX-2 expression is correlated with age.

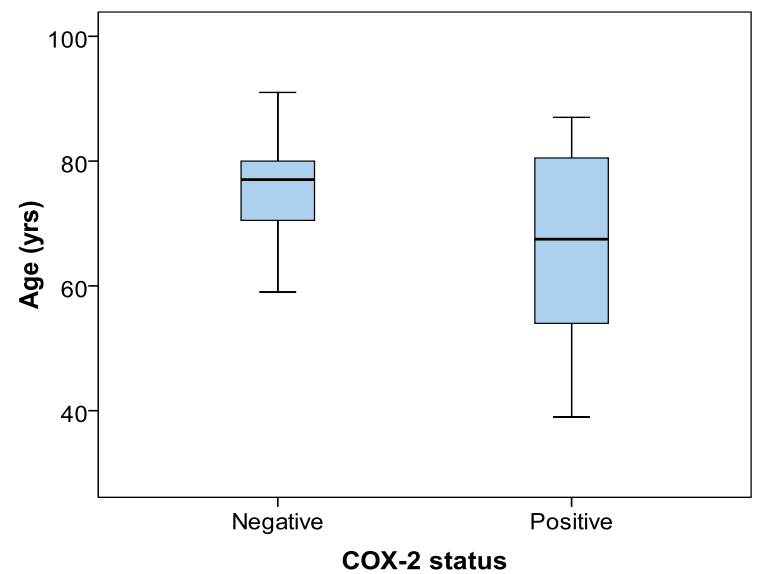

Figure 12: Correlation between COX-2 expression and age. For COX-2 negative expression the minimum value is 59 years and the maximum value is 91 years, with a mean of 75.45 years and a standard deviation of 8.251 years. For COX-2 positive expression the minimum value is 39 years and the maximum value is 87 years, with a mean of 65.65 years and a standard deviation of 16.027 years.

No statistic significance was found between tumor size and COX-2 positivity $(\mathrm{p}=0.725)$. Minimum value for tumor size was the same in both positive and negative COX-2 groups (1 $\mathrm{cm})$. The tumor size mean values for both groups are very similar, $3.95 \mathrm{~cm}$ for negative and $3.36 \mathrm{~cm}$ for positive COX-2 group (see annex 3). Standard deviation values were also closest, $2.709 \mathrm{~cm}$ and $2.952 \mathrm{~cm}$ for negative and positive COX-2 group (see figure 13).

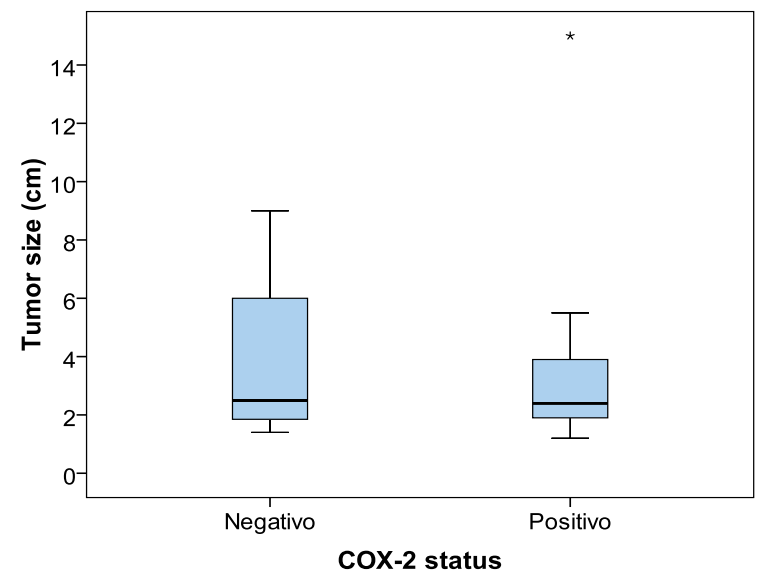

Figure 13: Correlation between COX-2 expression and tumor size. For COX-2 negative expression the minimum value is $1 \mathrm{~cm}$ and the maximum value is $9 \mathrm{~cm}$, with a mean of $3.95 \mathrm{~cm}$ and a standard deviation of $2.709 \mathrm{~cm}$. For COX-2 positive expression the minimum value is $1 \mathrm{~cm}$ and the maximum value is $15 \mathrm{~cm}$, with a mean of $3.36 \mathrm{~cm}$ and a standard deviation of $2.952 \mathrm{~cm}$. 
Even considering 2 groups of breast cancer (see figure 14), one with better prognosis tumors, with less than $2 \mathrm{~cm}(\mathrm{~T} 1)$ and other with worst prognostic disease, with size of 2 or more $\mathrm{cm}$, it was not found statical significance between tumor size and COX-2 imunopositivity $(\mathrm{p}=$ 0.510) (see annex 4).

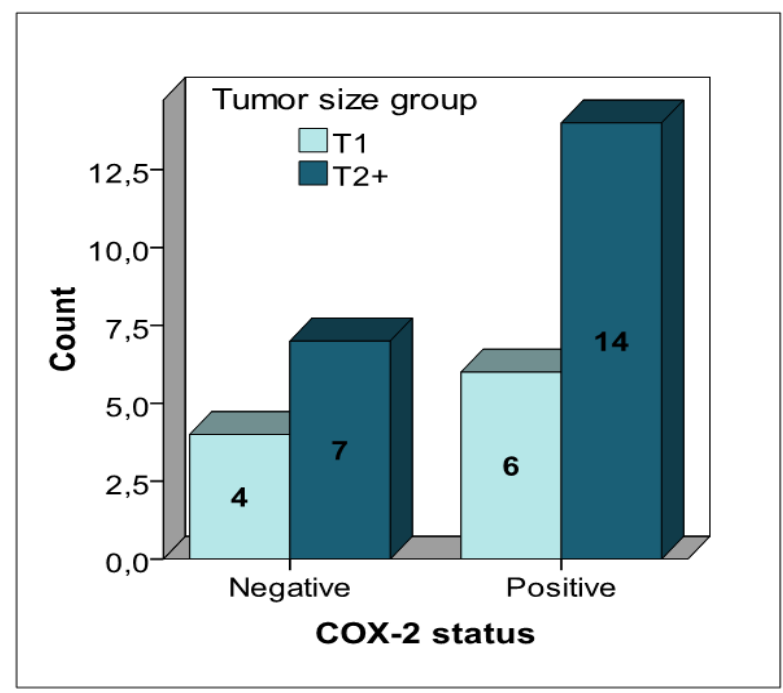

Figure 14: Correlation between COX-2 expression and age, considering 2 groups. For COX-2 negative expression there are 4 tumors with less than $2 \mathrm{~cm}$ and 7 tumors with $2 \mathrm{~cm}$ or more. For COX-2 positive expression there are 6 cases with less than $2 \mathrm{~cm}$ and 14 cases with $2 \mathrm{~cm}$ or more.

Tumor histologic grade was considered as low risk for $\mathrm{G} 1$ tumors and high risk for $\mathrm{G} 2$ and $\mathrm{G} 3$ tumors. Of $\mathrm{G} 1$ histologic grade was recorded in $22.6 \%$ cases and $77.4 \%$ was classified as $\mathrm{G} 2$ and $\mathrm{G} 3$ histologic grade (see annex 5). Six cases (30.0\%) with G1 histologic grade and 14 cases (70.0\%) with $\mathrm{G} 2$ and $\mathrm{G} 3$ histologic grade were reported as positive for COX-2 immunostaining. Negative COX-2 expression group was found in 1 case (9.1\%) with G1 histologic grade and in 10 cases (90.9\%) with high G2 or G3 histologic grade (see figure 15).

There was not found any statistical significance correlation between COX-2 imuno-positivity and tumor hitological grade $(p=0.192)$. 


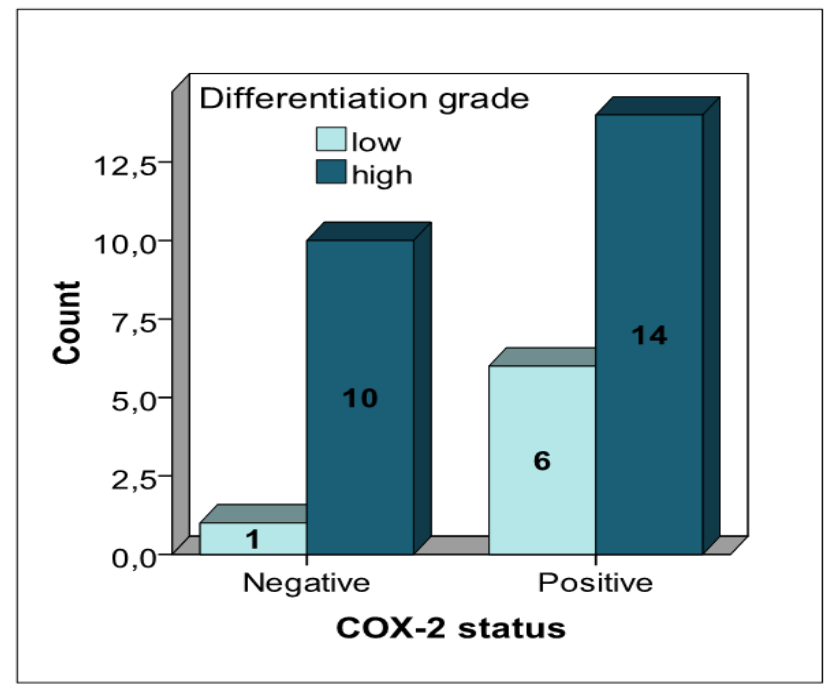

Figure 15: Correlation between COX-2 expression and differentiation grade. For COX-2 negative expression there is 1 tumor with low differentiation grade and 10 tumors with G2 or G3 histologic grade. For COX-2 positive expression there are 6 tumors with low differentiation grade and 14 tumors with G2 or $\mathrm{G} 3$ histologic grade.

Axillary node metastasis were documented in 9 of 31 cases $(29.0 \%)$ the percentage of cases positive and negative for axillary node metastasis $(54.5 \%)$ were very similar $(45.5 \%)$ in those negative COX-2 tumors (see annex 6). In positive COX-2 cases the results are much different; there were 16 cases with no axillary node metastasis $(80 \%)$ and 4 cases with axillary node metastasis (20\%) (see figure 16). However, statistical analysis have not showed significance between COX-2 positivity and axillary node metastasis $(p=0.140)$.

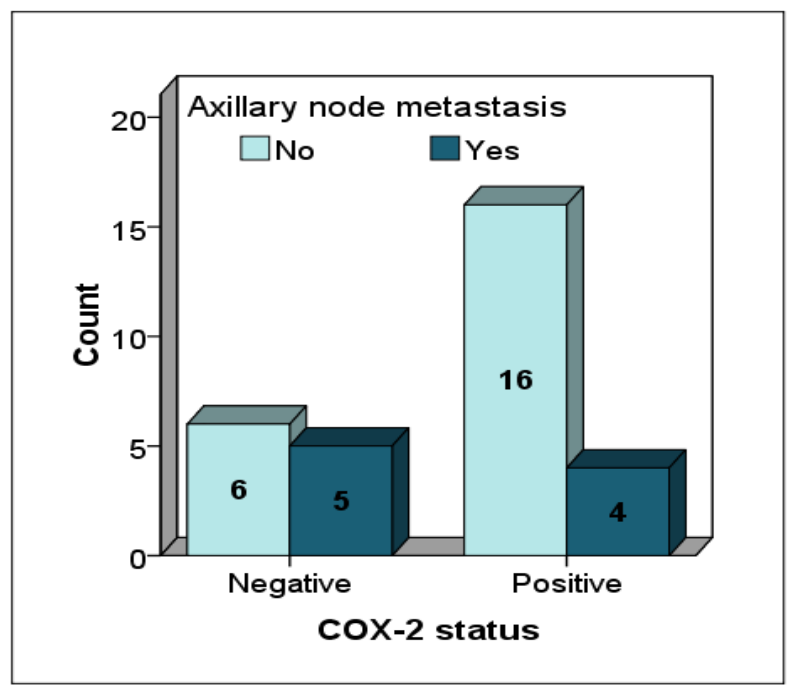

Figure 16: Correlation between COX-2 expression and axillary node metastasis. In 16 of the 20 women whose tumors overexpressed COX-2 there was no axillary node metastasis and in 4 of them there was axillary node metastasis. In tumors with negative COX-2 expression, 6 of 11 women had no axillary node metastasis and 5 of them had axillary node metastasis. 


\section{Correlation between Clinicopathologic Factors and Progesterone Receptor Expression}

Fourteen cases were considered imunopositive for PR and 17 tumors were negative.

The age of the patients was not statistically correlated with positivity for PR (see annex 7).

The minimum age of the patients with tumors negative and positive to PR was the same, however, the group of the patients with tumors positive for PR expression, seemed more heterogeneous in considering the age, with a higher mean and higher standard deviation age (see figure 17).

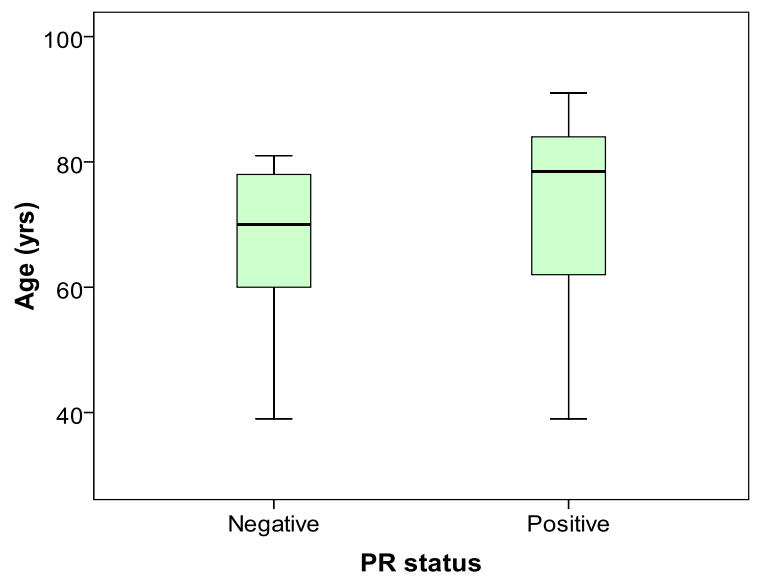

Figure 17: Correlation between PR expression and age. For PR negative expression the minimum value is 39 years and the maximum value is 81 years, with a mean of 67.59 years and a standard deviation of 11.609 years. For PR positive expression the minimum value is 39 years and the maximum value is 91 years, with a mean of 71 years and a standard deviation of 17.537 years.

Negative PR group had a higher mean $(4.60 \mathrm{~cm})$ and higher standard deviation $(3.471 \mathrm{~cm})$ than positive PR expression group which has a mean value of $2.32 \mathrm{~cm}$ and a standard deviation value of $0.816 \mathrm{~cm}$ (see figure 18). Negative PR expression group have tumors with higher size than positive PR expression group and is a more heterogeneous group than positive PR expression group.

The PR positive tumors were statistically significant smaller then PR negative tumors (see annex 8$)$. There is statistical significance $(p=0.032)$. 


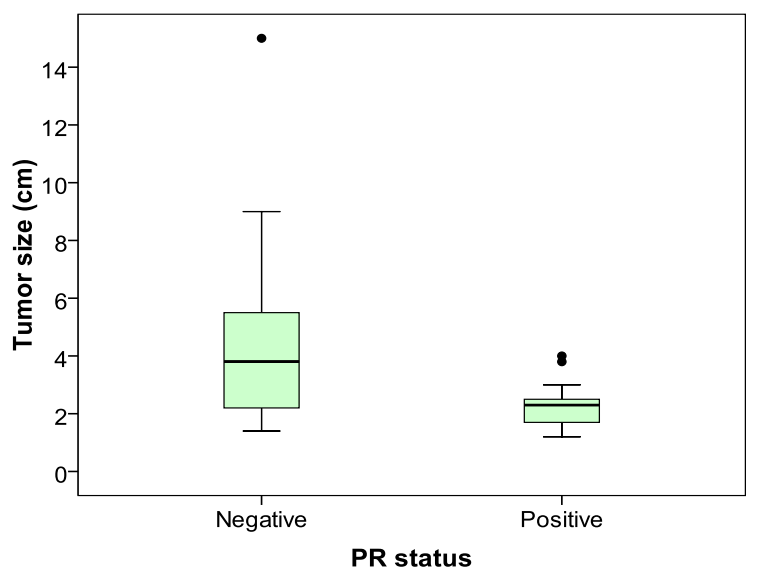

Figure 18: Correlation between PR expression and tumor size. For PR negative expression the minimum value is $1 \mathrm{~cm}$ and the maximum value is $15 \mathrm{~cm}$, with a mean of $4.60 \mathrm{~cm}$ and a standard deviation of $3.471 \mathrm{~cm}$. For PR positive expression the minimum value is $1 \mathrm{~cm}$ and the maximum value is $4 \mathrm{~cm}$, with a mean of $2.32 \mathrm{~cm}$ and a standard deviation of $0.816 \mathrm{~cm}$.

As reported earlier tumor differentiation grade was considered as low risk (G1) or high risk (G2 or G3) and it was correlated with PR expression groups.

In negative PR group 15 of 17 cases (88.2\%) had G2 or G3 differentiation grade and in positive PR group 9 of 14 cases (64.3\%) had G2 and G3 histologic grade (see figure 19).

When PR immunostaininig is negative it seems that tumors tend to be a higher risk histologic grade, however, there is no statistical significance $(p=0.124)$ (see annex 9).

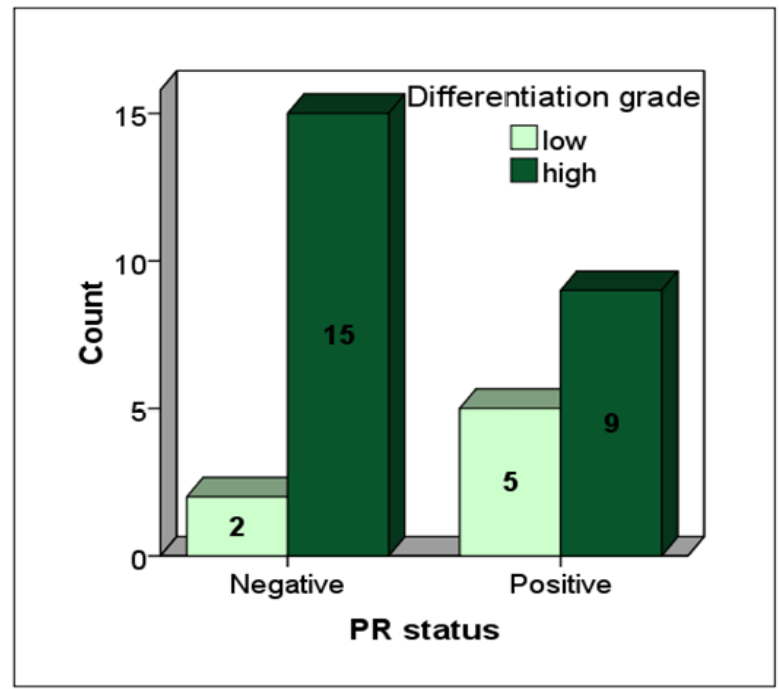

Figure 19: Correlation between PR expression and differentiation grade. For PR negative expression there are 2 tumors with low differentiation grade and 15 tumors with $\mathrm{G} 2$ or $\mathrm{G} 3$ histologic grade. For PR positive expression there are 5 tumors with low differentiation grade and 9 tumors with G2 or G3 histologic grade. 
In tumors with immunopositivity for PR there were 13 of 14 (92.9\%) cases without axillary nodes metastasis (see figure 20). PR negative immunostaining was strongly statistically associated with presence of axillary node metastasis $(p=0.018)($ see annex 10$)$.

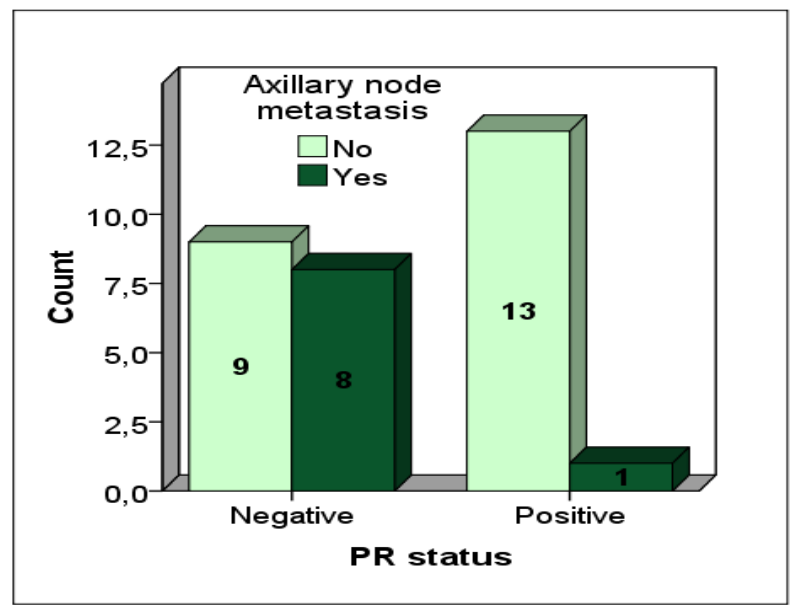

Figure 20: Correlation between PR expression and axillary node metastasis. In 13 of women whose tumors expressed PR there was no axillary node metastasis and in 1 of them there was axillary node metastasis. In tumors with negative PR expression, 9 women had no axillary node metastasis and 8 of them had axillary node metastasis.

\section{Correlation between Progesterone Receptor Expression and Clinicopathologic Factors according to Cyclooxygenase-2 Expression}

In order to evaluate any association between PR and COX-2 immunoexpression it was constituted 4 groups: positive COX-2 expression with positive PR expression (COX $\left.-2^{+} / \mathrm{PR}^{+}\right)$, positive COX-2 expression with negative PR expression (COX-2 $\left.{ }^{+} / \mathrm{PR}^{-}\right)$, negative COX-2 expression with positive PR expression (COX-2 $\left./ \mathrm{PR}^{+}\right)$and negative COX-2 expression with negative PR expression (COX-2 / PR $\left.^{-}\right)$.

COX $-2^{+} / \mathrm{PR}^{+}$group is constituted for 11 of 31 cases $(35.48 \%)$, COX-2 ${ }^{+} / \mathrm{PR}^{-}$group is constituted for 9 of 31 cases (29.03\%), COX-2 /PR group is constituted for 3 of 31 cases (9.68\%) and COX2 /PR group is constituted for 8 of 31 cases $(25.81 \%)$ (see table 2 ).

Table 2: Correlation between COX-2 and PR expression.

\begin{tabular}{|c|c|c|c|}
\hline & $\begin{array}{c}\text { COX-2 negative } \\
\text { expression }\end{array}$ & $\begin{array}{c}\text { COX-2 positive } \\
\text { expression }\end{array}$ & Total \\
\hline $\begin{array}{c}\text { PR negative } \\
\text { expression }\end{array}$ & $\mathrm{n}=8(25.81 \%)$ & $\mathrm{n}=9(29.03 \%)$ & $\mathrm{n}=17(54.84 \%)$ \\
\hline $\begin{array}{c}\text { PR positive } \\
\text { expression }\end{array}$ & $\mathrm{n}=3(9.68 \%)$ & $\mathrm{n}=11(35.48 \%)$ & $\mathrm{n}=14(45.16 \%)$ \\
\hline Total & $\mathrm{n}=11(35.49 \%)$ & $\mathrm{n}=20(64.51 \%)$ & $31(100 \%)$ \\
\hline
\end{tabular}


As it can be seen in figure 21 a) and b), in patient age analysis, the group $\mathrm{COX}-2^{+} / \mathrm{PR}^{+}$is the more heterogeneous and showed the higher value. Patients in the group $\mathrm{COX}-2{ }^{-} / \mathrm{PR}^{+}$seems to be the more aged with mean age of 83 years (see annex 11).
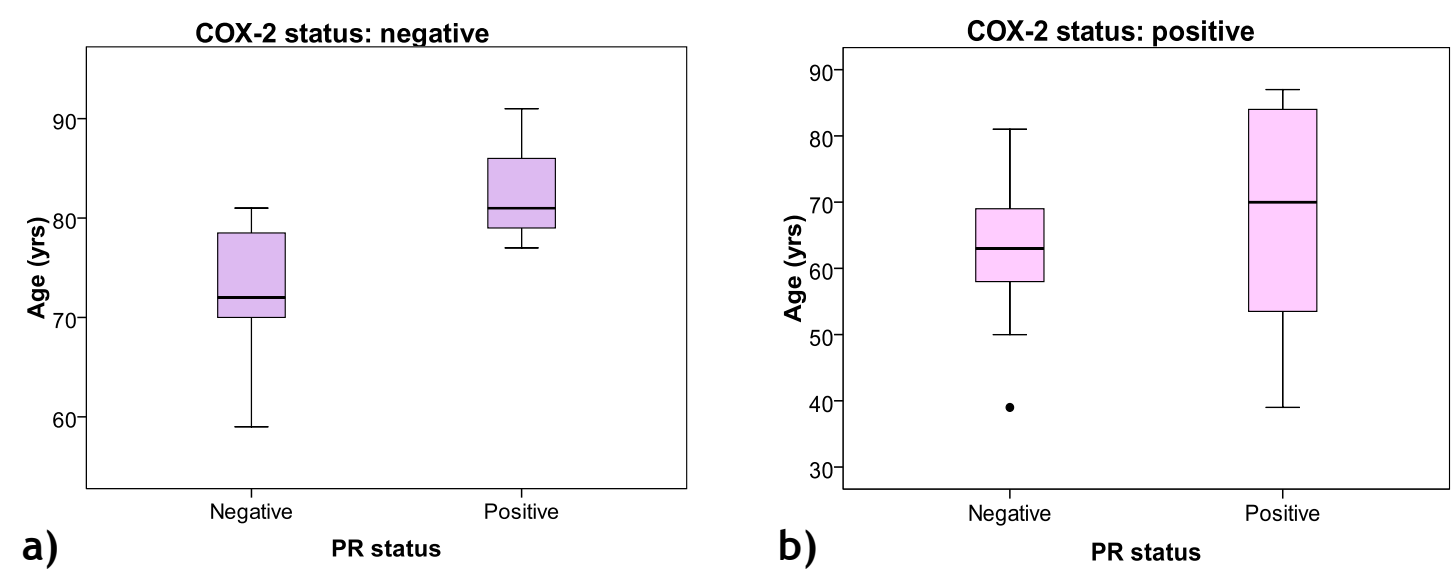

Figure 21: Correlation between PR expression and age according to COX-2 expression. a) The COX-2 /PR group is more heterogeneous than $\mathrm{COX}-2^{-} / \mathrm{PR}^{+}$group, with a standard deviation of 6.989 years. COX-2$/ \mathrm{PR}^{+}$has a higher mean and median than $\mathrm{COX}-2^{-} / \mathrm{PR}^{-}$group. b) $\mathrm{COX}-2^{+} / \mathrm{PR}^{+}$group has a higher mean and standard deviation than $\mathrm{COX}-2^{+} / \mathrm{PR}^{-}$group

Evaluating tumor size, the COX-2/PR group has shown to be the more heterogeneous (see figure 22a), ranging the size from $10 \mathrm{~mm}$ to $90 \mathrm{~mm}$, and the group $C O X-2 \% \mathrm{PR}^{+}$the more homogeneous (see annex 12). Comparing COX-2 positive expression group it was found that the size of the COX $-2^{+} / \mathrm{PR}^{+}$were statistically smaller that $\mathrm{COX}-\mathrm{2}^{+} / \mathrm{PR}^{-}$group (see figure $22 \mathrm{~b}$ ), there is statistical significance $(p=0.043)$.
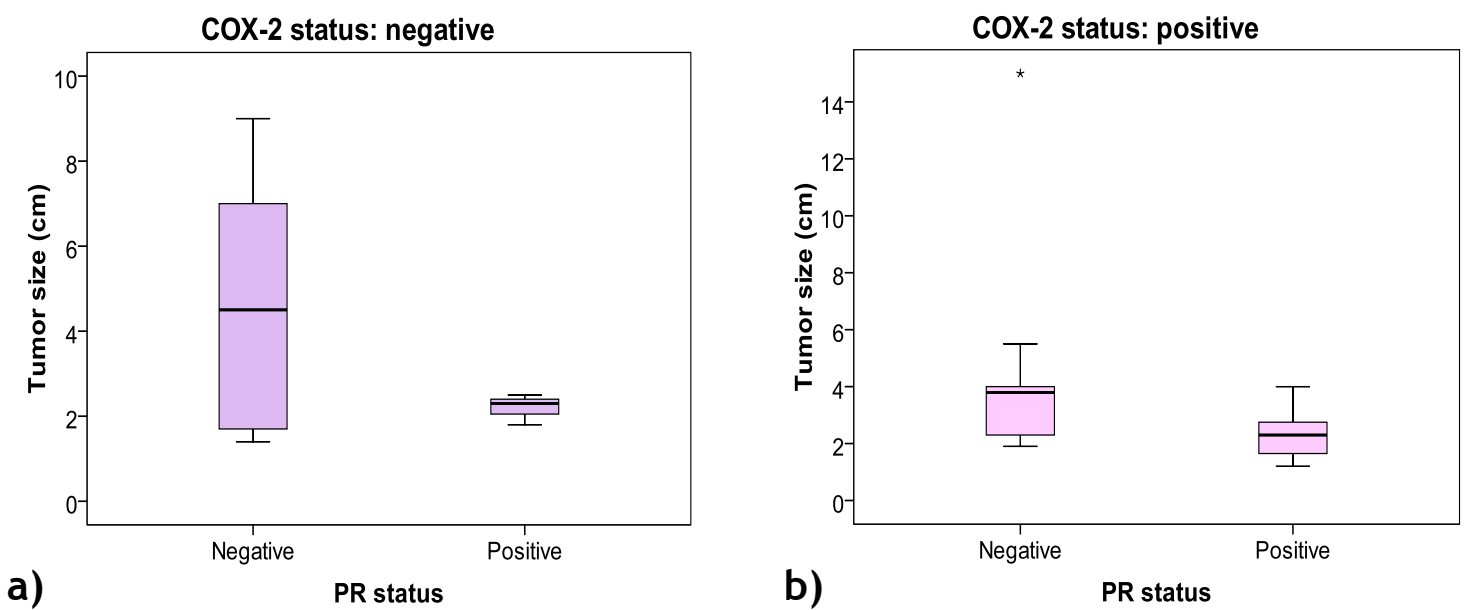

Figure 22: Correlation between PR expression and tumor size according to COX-2 expression. a) The COX $-2^{-} / \mathrm{PR}^{-}$group is more heterogeneous and has higher mean than COX-2 $/ \mathrm{PR}^{+}$group, with a standard deviation of $2.941 \mathrm{~cm}$ and a mean of $4.60 \mathrm{~cm}$. b) $\mathrm{COX}-2^{+} / \mathrm{PR}^{+}$group has a lower mean and standard deviation than $\mathrm{COX}-2^{+} / \mathrm{PR}^{-}$group. 
There are 10 cases with high differentiation grade, 8 of them belong to COX-2 /PR group and in this group there is no low differentiation grade, the number of high differentiation grade represents $100 \%$ (see figure 23 a and b). For COX-2 $/ \mathrm{PR}^{+}$group there are 2 cases with high differentiation grade and 1 case with low differentiation grade, which represents $66.7 \%$ and $33.3 \%$, respectively (see annex 13 ).

For $\mathrm{COX}-2^{+} / \mathrm{RP}^{-}$group there are 2 of 9 cases $(22.2 \%)$ with low differentiation grade and 7 of 9 cases $(77.8 \%)$ with high differentiation grade. Similar results were obtained for $\mathrm{COX}-2^{+} / \mathrm{PR}^{+}$ group, 4 of 11 cases (26.4\%) have low differentiation grade and 7 of 11 cases (63.6\%) have high differentiation grade.

All groups have more cases of high differentiation grade, and there is no statistical significance for any group. Negative COX-2 expression group has a P-value $=0.273$ and positive COX-2 expression group has a $\mathrm{P}$-value $=0.426$.

COX-2 status: negative

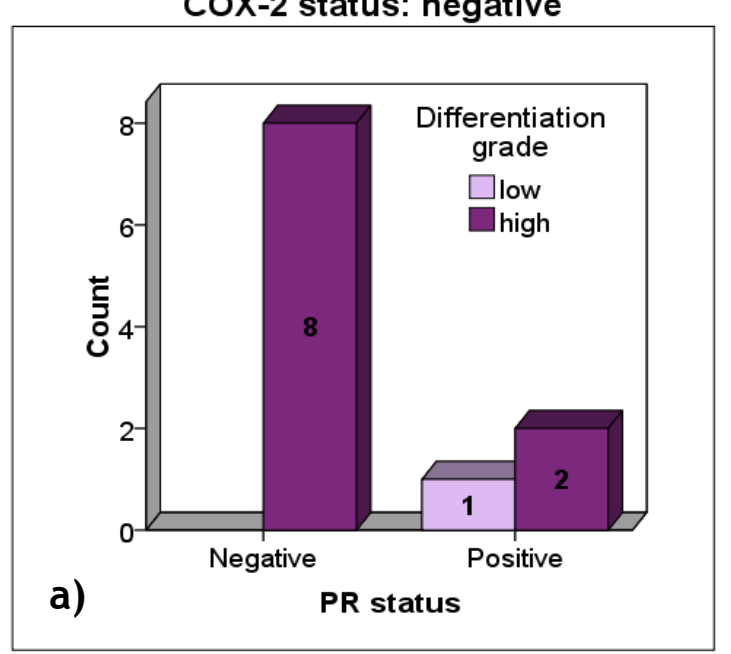

COX-2 status: positive

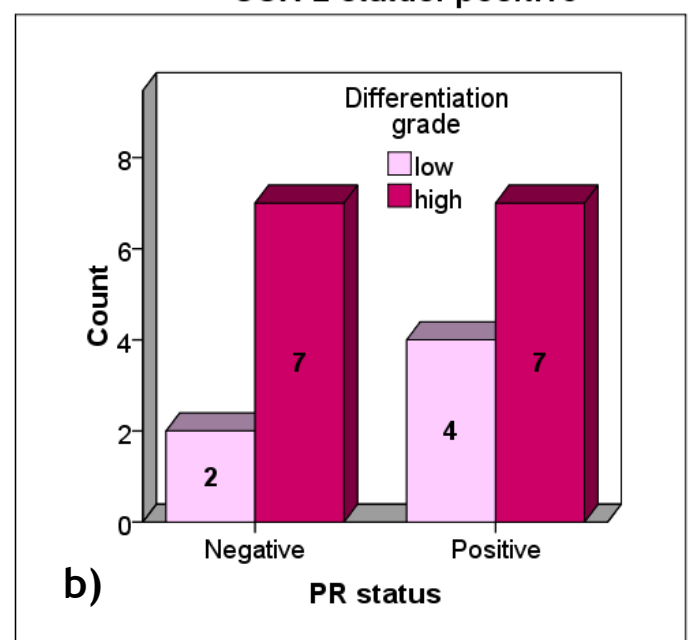

Figure 23: Correlation between PR expression and differentiation grade according to COX-2 expression. a) In COX-2 /PR group all tumors have a high differentiation grade and in COX-2 /PR ${ }^{+}$group there is only one case with low differentiation grade. b) For COX-2 positive expression group tumors with PR positive expression have higher number of cases with low differentiation grade (G1).

For negative COX-2 expression group 6 of 11 (54.55\%) women had no axillary node metastasis (see annex 14).

In COX-2 /PR group $50 \%$ of women had axillary node metastasis and in COX-2 $/ \mathrm{PR}^{+}$group there was only 1 woman with axillary node metastasis (33.3\%) (see figure 24a). For negative COX-2 expression group there was not found statistical significance $(P$-value $=0.576)$.

For positive COX-2 expression group there are 16 of 20 women $(80 \%)$ without axillary node metastasis and 4 of 20 women (20\%) with axillary node metastasis (see figure $24 \mathrm{~b}$ ). 
COX-2 status: negative

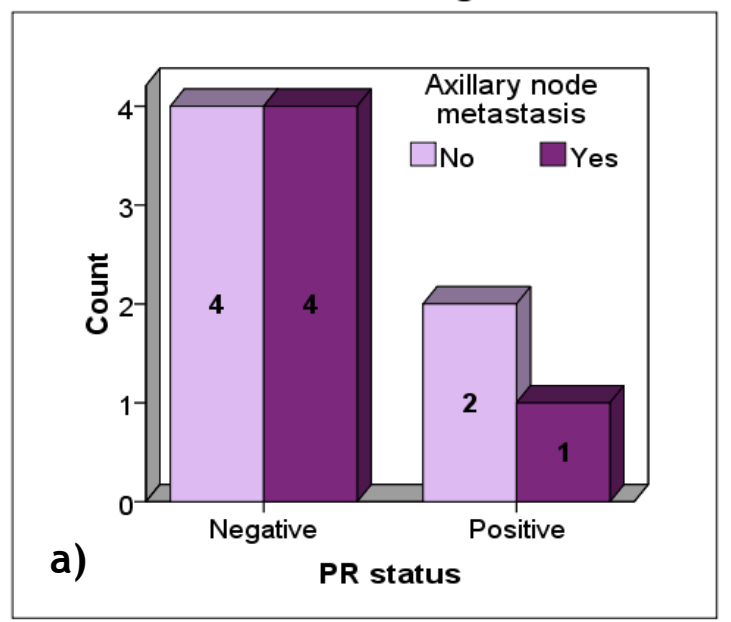

COX-2 status: positive

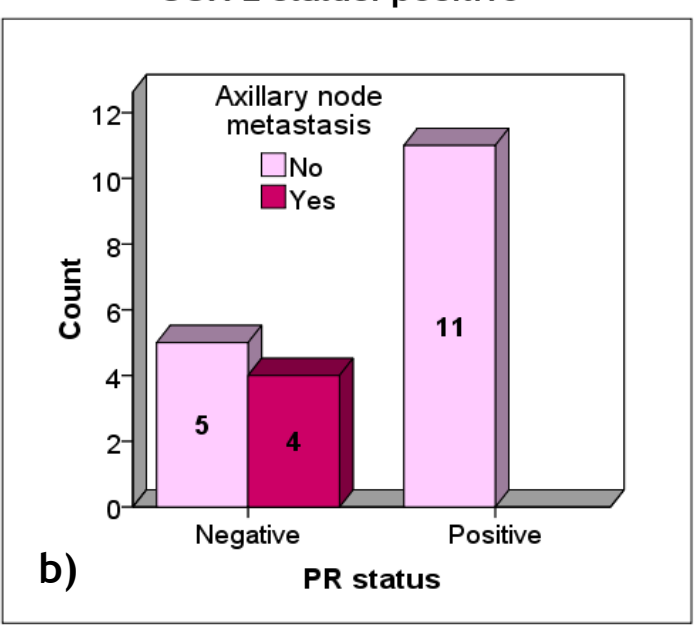

Figure 24: Correlation between PR expression and axillary node metastasis according to COX-2 expression. a) In COX-2 $/ \mathrm{PR}^{-}$there is the same number of cases with and without axillary node metastasis, for PR negative expression there are more cases without axillary node metastasis. b) COX$2^{+} / \mathrm{PR}^{-}$has a higher number of cases with axillary node metastasis than $\mathrm{COX}-2^{+} / \mathrm{PR}^{+}$group, which has only cases without axillary node metastasis.

There were nine women whose tumors were COX-2 $/ \mathrm{PR}$, and $5(55.6 \%)$ of them had no axillary node metastasis. In $\mathrm{COX}-2^{+} / \mathrm{PR}^{+}$group all women $(100 \%)$ had no axillary node metastasis. These groups are statistical related $(P$-value $=0.026)$. 


\section{Chapter 4: Discussion}

COX-2 is the induced cyclooxygenase isoform, is expressed in most of the tissues and commonly expressed in more than $50 \%$ of invasive breast cancers (Haffty et al. 2008; SinghRanger et al. 2008). COX-2 is involved in chronic inflammation and is responsible for AA conversion into prostaglandins, which are associated with increased aromatase that in turn, results in high local ER (Mendelson and Hardy 2006; Schetter et al. 2010).

ER upregulation is associated with breast cancer progression and PR has been considered has an estrogen-induced target gene (Cui et al. 2005). However, Hardy et al. found that PR expression is an independent predictor of breast cancer diagnosis (Hardy et al. 2008). PR is a COX-2 and aromatase inhibitor and plays an important anti-inflammatory and protective role in breast cancer (Hardy et al. 2008).

Based on these findings we attempted to determine a relation between COX-2 expression, PR expression and clinicopathologic factors (age, tumor size, histologic grade and axillary node metastasis), which are known to be prognostic factors.

As previously reported, our study was performed in 31 women with invasive ductal breast cancer and COX-2 expression was detected by semiquantitative scoring in $64.52 \%$ of tumors. These results are consistent with those of Haffty et al., who found COX-2 expression in $58 \%$ of women $(n=504)$ with breast cancer (Haffty et al. 2008).

When we performed a comparative study between COX-2 expression and age, we observed that the tumors with COX-2 expression had a tendency for incidence in younger ages, once all women with 50 years or less $(n=5)$ had COX-2 expression. However, that results have shown no statistical significance $(p=0.121)$ probably due to the reduced number of cases. Haffty et al. found similar results: nearly $70 \%$ of women with less than 40 years of age expressed COX-2 and these results are consistent with those of Ristmäki et al. and Denkert et al. studies (Ristimäki et al. 2002; Denkert et al. 2003; Haffty et al. 2008).

Previous studies have also reported that tumors with COX-2 expression were higher than $2 \mathrm{~cm}$ (Ristimäki et al. 2002; Denkert et al. 2003; Haffty et al. 2008), however, in our study, COX-2 expression and tumor size were not statistical related $(p>0.005)$, probably due to the low number of cases in the study.

Correlating COX-2 expression with histologic grade and with axillary node metastasis we found no statistical association between them. The group of tumors that expressed COX-2 and the group of tumors that has no COX-2 expression had similar number of cases with high histologic grade. However, other researchers concluded that COX-2 expression is associated with high histologic grade (Ristimäki et al. 2002; Denkert et al. 2003). In our study axillary node 
metastasis was negatively associated with COX-2 expression and this is inconsistent with previous studies. We found less than expected axillary node metastasis in the group of tumors with COX-2 expression, compared with the group of tumors that has no COX-2 expression. Ristimäki et al. and Denkert et al obtained opposite results, there was a higher incidence of cases with axillary node metastasis when there was COX-2 expression, concluding that COX-2 expression is related to axillary node metastasis (Ristimäki et al. 2002; Denkert et al. 2003). Probably, one way to explain this results disparity may be the inclusion of different types of breast cancer in studies of Ristimäki et al. and Denkert et al.(Ristimäki et al. 2002; Denkert et al. 2003).

Clinicopathologic factors there were also statistical compared with PR expression. By semiquantitative scoring there was found that PR expression was present in $45.16 \%$ of the cases, being this result in according with previous studies (Lee et al. 2010).

In our study we found no statistical significance between PR expression and age and histologic grade, although, the group with negative PR expression has shown a tendency to higher incidence of tumors with high histologic grade.

We found statistical relation $(\mathrm{p}=0.032)$ between tumor size and PR status. Tumors with smaller size had PR expression. Similar statistical significance were obtained when PR expression was compared with axillary node metastasis $(p=0.018)$. These results suggest that $\mathrm{PR}$ expression might have a protective role in breast cancer.

It was not possible to establish association between COX-2 expression and clinicopathologic factors, COX-2 expression seems to appear in younger patients, it is also possible to $b$ related with COX-2 increased risk for axillary node metastasis. Several studies have been conducted in order to establish a relationship between COX-2 expression and clinicopathologic factors (Haffty et al. 2008). Ristimäki et al., Denkert et al. and Haffty et al. concluded that the COX2 expression is related to tumor appearance at early ages, higher tumor size, histological grade and axillary lymph node metastasis (Ristimäki et al. 2002; Denkert et al. 2003; Haffty et al. 2008). But as in the present study, Lee et al. also found no significant correlation between COX-2 expression and clinicopathologic factors, probably due to the reduced data set (Lee et al. 2010).

In our study, we could establish a relation between PR and COX-2 expression with the studied clinicophtologic factors, but these results have no concordance with the ones found for Lee et al. who did not establish this correlation (Lee et al. 2010). Probably that discrepancy was due to the methodology used. They considered $>10 \%$ PR or COX-2 of staining as a positive case and in our study only the cases with at least $50 \%$ of staining were considered as positive. Our methodology seems more reasonable in order to avoid false positive cases. 
When both PR and COX-2 expression were compared with age, patients with tumors COX-2 $/ \mathrm{PR}^{+}$seems to be younger, although COX-2 expression, $\mathrm{PR}$ expression and age are not statistical related $(p>0.05)$.

Tumors $\mathrm{COX}-2^{+} / \mathrm{PR}^{+}$were smaller that those with $\mathrm{COX}-2^{+} / \mathrm{PR}^{-}(\mathrm{p}=0.043)$. Comparing axillary node metastasis with COX-2 expression and PR expression we found that none of the patients whose tumors expressed PR had axillary node metastasis. As previously reported, PR is related with axillary node metastasis, taken this together with COX-2 expression, it is possible that PR may have a protective role in breast cancer.

Is known that PR positive breast cancer is associated with a better prognosis and negative PR expression is worse signal (Bardou et al. 2003). It was suggested benefits for chemotherapy in PR negative breast cancer, including small or intermediated size and node negative cancers, in according with bad prognosis of this kind of breast cancers (National Institutes of Health 2000).

Despite PR protective role in breast cancer is unclear, Hardy et al. verified in cellular breast cancer lines, that PR antagonizes COX-2 expression (Hardy et al. 2008). PR acts as a ligand dependent and independent way to inhibit NF-kB (COX-2 transcriptional factor) transactivation (Mendelson and Hardy 2006; Hardy et al. 2008). PR interferes with COX-2 transactivation through NF-kB, via IkBa induction, which modulates COX-2 expression (Hardy et al. 2008).

COX-2 expression is related with increased expression of aromatase, and consequent local increase of ER, PR expression might decrease aromatase induction, with consequent decrease of local ER (Mendelson and Hardy 2006; Hardy et al. 2008).

Thus, decreased local ER levels occur as a result of decreased expression of COX-2 (Mendelson and Hardy 2006; Hardy et al. 2008).

This modulating role, played by $\mathrm{PR}$ can be one of the reasons to the $\mathrm{ER}^{+} / \mathrm{PR}^{-}$hormone tumors are more aggressive and have higher proliferation rates when compared with $E R^{-} / \mathrm{PR}^{+}$tumors (Arpino et al. 2005). ER $/ \mathrm{PR}^{-}$tumors are more resistant to adjuvant treatment, specially to tamoxifen and endocrine therapy, progesterone treatment may be an important consideration (Bardou et al. 2003; Arpino et al. 2005).

Thus, high levels of PR in breast epithelial cells play a protective role in breast cancer, by modulating inflammatory response pathway. Despite have been provided evidences that there is a relationship between PR lower expression, COX-2 expression and aggressiveness of breast cancer, further studies are needed to clarify all the mechanisms by which PR plays an inflammatory role in this type of cancer. 
Our results suggest that ductal invasive breast cancer PR positive may have different prognosis in according of COX-2 expression. In fact, those cancers COX- $2^{+} / \mathrm{PR}^{+}$seems to have different behavior of $\mathrm{COX}-2^{+} / \mathrm{PR}^{-}$, and $\mathrm{COX}-2^{+} / \mathrm{PR}^{+}$immunoexpression represents a marker for better prognosis. We speculate if COX-2 expression will be related with better disease-free survival and overall-survival in patients immunopositive for PR submitted to adjuvant hormonal therapy.

Further studies may clarify the usefulness of the COX-2 immunostaining in clinical practice. 


\section{Chapter 5: Conclusion}

The purpose for this study was to perform a correlation between COX-2 expression, PR expression and clinicopathologic factors in breast cancer, through an immunostaining evaluation.

There was found a positive association between PR expression between breast tumor size and axillary node metastasis.

$\mathrm{COX}-2^{+} / \mathrm{PR}^{+}$was associated with lower tumor size and lower incidence of axillary node metastasis.

These findings suggest that PR modulates COX-2 expression and its expression is related with better prognosis. Conversely, a decline PR expression is associated with an overall worse survival.

COX-2 seems to be a marker for good behaviour in ductal invasive breast cancer.

We speculate if COX-2 determination may have be a clinical usefulness in clinical practice. It's expected that further studies may clarify this issue. 


\section{Bibliography}

Abdel-Hafiz, H., Dudevoir, M. and Horwitz, K. (2009). "Mechanisms underlying the control of progesterone receptor transcriptional activity by SUMOylation." The Journal of Biological Chemistry 284: 9099-9108.

Allavena, P., Garlanda, C., Borrello, M., Sica, A. and Mantovani, A. (2008). "Pathways connecting inflammation and cancer." Current Opinion in Genetics \& Development 18: 3-10.

Arpino, G., Weiss, H., Lee, A., Schiff, R., Placido, S. D., Osborne, C. and Elledge, R. (2005). "Estrogen receptor positive, progesterone receptor-negative breast cancer: association with growth factor receptor expression and tamoxifen resistance." Journal of the National Cancer Institute 97: 1254-1261.

Balkwill, F., Charles, K. and Mantovani, A. (2005). "Smoldering and polarized inflammation in the initiation and promotion of malignant disease." Cancer Cell 7: 211-217.

Bardou, V.-J., Arpino, G., Elledge, R., Osborne, C. and Clark, G. (2003). "Progesterone receptor status significantly improves outcome prediction over estrogen receptor status alone for adjuvant endocrine therapy in two large breast cancer databases." Journal of Clinical Oncology 21: 1973-1979.

Bassères, D. and Baldwin, A. (2006). "Nuclear factor-kB and inhibitor of $k B$ kinase pathways in oncogenic initiation and progression." Oncogene 25: 6817-6830.

Benoit, V., Relic, B., Leval, X. d., Chariot, A., Merville, M.-P. and Bours, V. (2004). "Regulation of HER-2 oncogene expression by cyclooxygenase-2 and prostaglandin E2." Oncogene 23: 1631-1635.

Cui, X., Schiff, R., Arpino, G., Osborne, C. and Lee, A. (2005). "Biology of progesterone receptor loss in breast cancer and its implications for endocrine therapy." Journal of Clinical Oncology 23: 7721-7735.

Danaei, G., Hoorn, S., Lopez, A. D., Murray, C. and Ezzati, M. (2005). "Causes of cancer in the world: comparative risk assessment of nine behavioural and environmental risk factors." Lancet 366: 1784-1793.

Dannenberg, A. and Howe, L. (2003). "The role of COX-2 in breast and cervical cancer". COX2: A new target for cancer prevention and treatment. Dannenberg, A. J. and DuBois, R. N. New York, Karger. 37: 90-106. 
Davies, G., Martin, L.-A., Sacks, N. and Dowsett, M. (2002). "Cyclooxygenase-2 (COX-2), aromatase and breast cancer: a possible role for COX-2 inhibitors in breast cancer chemoprevention." Annals of Oncology 13: 669-678.

DeNardo, D. G. and Coussens, L. (2007). "Inflammation and breast cancer. Balancing immune response: crosstalk between adaptive and innate immune cells during breast cancer progression." Breast Cancer Research 9: 212.

Denkert, C., Winzer, K.-J., Müller, B.-M., Weichert, W., Pest, S., Köbel, M., Kristiansen, G., Reles, A., Siegert, A., Guski, H. and Hauptmann, S. (2003). "Elevated expression of cyclooxygenase-2 is a negative prognostic factor for disease free survival and overall survival in patients with breast carcinoma." Cancer 97: 2978-2987.

Ferlay, J., Parkin, D. and Steliarova-Foucher, E. (2010). "Estimates of cancer incidence and mortality in Europe in 2008." European Journal of Cancer 46: 765-781.

Gately, S. and Kerbel, R. (2003). "Therapeutic potential of selective cycloocygenase-2, inhibitors in the management of tumor angiogenesis". COX-2: A new target for cancer prevention and treatment. Dannenberg, A. J. and DuBois, R. N. New York, Karger. 37: 179-192.

Grivennikov, S., Greten, F. and Karin, M. (2010). "Immunity, inflammation, and cancer." Cell 140: 883-899.

Haffty, B., Yang, Q., Moran, M., Tan, A. and Reiss, M. (2008). "Estrogen-dependent prognostic significance of cyclooxygenase-2 expression in early-stage invasive breast cancers treated with breast-conserving surgeryand radiation." International Journal of Radiation Oncology • Biology • Physics 71: 1006-1013.

Hardy, D., Janowski, B., Chen, C.-C. and Mendelson, C. (2008). "Progesterone receptor inhibits aromatase and inflammatory response pathway in breast cancer cells via ligand-dependet and ligand-independent mechanisms." Molecular Endocrinology 22: 1812-1824.

Henderson, B. and Feigelson, H. (2000). "Hormonal carcinogenesis." Carcinogenesis 21: 427433.

Howe, L., Subbaramaiah, K., Brown, A. and Dannenberg, A. (2001). "Cyclooxygenase-2: a target for the prevention and treatment of breast cancer." Endocrine-related Cancer 8: 97-114. 
Hu, M., Peluffo, G., Chen, H., Gelman, R., Schnitt, S. and Polyak, K. (2008). "Role of COX-2 in epithelial-stromal cell interactions and progression of ductal carcinoma in situ of the breast." PNAS 106: 3372-3377.

Isakson, P. (2003). "Pharmacology of COX-2 inhibitors". COX-2: A new target for cancer prevention and treatment. Dannenberg, A. J. and DuBois, R. N. New York, Karger. 37.

Karin, M. and Greten, F. (2005). "NF-KB: Linking inflammation and immunity to cancer development and progression " Nature Reviews Immunology 5: 749-759

Lee, J., Bae, J., Woo, S., Kim, H. and Kim, C. (2010). "Correlation between COX-2 expression and hormone receptors in invasive ductal breast cancer." Journal of Korean Surgical Society 78: 140-148.

Lin, W.-W. and Karin, M. (2007). "A cytokine-mediated link between innate immunity, inflammation, and cancer." The Journal of Clinical Investigation 117: 1175-1183.

Lu, H., Ouyang, W. and Huang, C. (2006). "Inflammation, a key event in cancer development." Molecular Cancer Research 4: 221-233.

Mantovani, A., Allavena, P., Sica, A. and Balkwill, F. (2008). "Cancer-related inflammation." Nature 454: 436-444.

Mendelson, C. and Hardy, D. (2006). "Role of the progesterone receptor (PR) in the regulation of inflammatory response pathways and aromatase in the breast." The Journal of Steroid Biochemestry \& Molecular Biology 102: 241-249.

National Institutes of health. (2000). "NIH Consensus Development on Adjuvant Therapy for Breast Cancer." National Institutes of Health.

Pitot, H. and Dragan, Y. (1991). "Facts and theories concerning the mechanisms of carcinogenesis." Federation of American Societies for Experimental Biology 5: 22802286.

Polyac, K. (2007). "Breast cancer: origins and evolution." The Journal of Clinical Investigation 117: 3155 - 3163.

Ristimäki, A., Sivula, A., Lundin, J., Lundin, M., Salminen, T., Haglund, C., Joensuu, H. and Isola, J. (2002). "Prognostic significance of elevated cyclooxygenase-2 expression in breast cancer." Cancer Research 62: 632-635. 
Ross, R., Paganini-Hill, A., Wan, P. and Pike, M. (2000). "Effect of hormone replacement therapy on breast cancer risk: estrogen versus estrogen plus progestin." Journal of the National Cancer Institute 92: 328-332.

Ruddon, R. (2007). "The epidemiology of human cancer". Cancer Biology. Ruddon, R. W. New York, Oxford University press. 4th ed.: 62-116.

Schetter, A., Heegaard, N. and Harris, C. (2010). "Inflammation and cancer: interweaving microRNA, free radical, cytokine and p53 pathways." Carcinogenesis 31: 37-49.

Schlehe, B. and Schmutzler, R. (2008). "Hereditary breast cancer." Der Chirurg 79: 1047-1054.

Singh-Ranger, G., Salhab, M. and Mokbel, K. (2008). "The role of cyclooxygenase-2 in breast cancer: review." Breast Cancer Research Treatment 109: 189-198.

Subbaramaiah, K., Howe, L., Port, E., Brogi, E., Fishman, J., Liu, C., Hla, T., Hudis, C. and Dannenberg, A. (2006). "HER-2/neu status is a determinant of mammary aromatase activity in vivo: evidence for a cyclooxygenase-2-dependent mechanism." Cancer Research 66: 5504-5511.

Thomas, W., Caiazza, F. and Harvey, B. (2008). "Estrogen, phospholipase A and breast cancer "Frontiers in Bioscience 13: 2604-2613. 


\section{Annexes}

\section{Annex 1}

Patients Data

\begin{tabular}{|c|c|c|c|c|c|c|c|c|c|}
\hline Patients & Age & Year & $\begin{array}{c}\text { COX-2 } \\
\text { immuno. }\end{array}$ & $\begin{array}{l}\text { COX-2 } \\
\text { exp. }\end{array}$ & $\begin{array}{c}\text { PR } \\
\text { immuno. }\end{array}$ & PR exp. & $\begin{array}{l}\text { Tumor } \\
\text { size }\end{array}$ & $\begin{array}{l}\text { Diff. } \\
\text { Grad. }\end{array}$ & $\begin{array}{l}\text { Axillary } \\
\text { node } \\
\text { metast. }\end{array}$ \\
\hline 1 & 39 & 2007 & + & $50 \%$ & + & $50 \%$ & $\begin{array}{c}16 \mathrm{~mm} \\
\sim 2 \\
\end{array}$ & G2 & Negative \\
\hline 2 & 43 & 2009 & + & $50 \%$ & + & $75 \%$ & $\begin{array}{c}23 \mathrm{~mm} \\
\sim 2\end{array}$ & G3 & Negative \\
\hline 3 & 45 & 2007 & + & $75 \%$ & + & $50 \%$ & $\begin{array}{c}12 \mathrm{~mm} \\
\sim 1\end{array}$ & G2 & Negative \\
\hline 4 & 66 & 2007 & + & $50 \%$ & + & $50 \%$ & $\begin{array}{c}19 \mathrm{~mm} \\
\sim 2\end{array}$ & G3 & Negative \\
\hline 5 & 67 & 2007 & ++ & $100 \%$ & ++ & $100 \%$ & $\begin{array}{c}16 \mathrm{~mm} \\
\sim 2\end{array}$ & G1 & Negative \\
\hline 6 & 70 & 2009 & + & $50 \%$ & + & $75 \%$ & $\begin{array}{c}23 \mathrm{~mm} \\
\sim 2 \\
\end{array}$ & G2 & Negative \\
\hline 7 & 80 & 2009 & + & $50 \%$ & + & $50 \%$ & $\begin{array}{c}25 \mathrm{~mm} \\
\sim 3\end{array}$ & G2 & Negative \\
\hline 8 & 84 & 2009 & + & $50 \%$ & + & $75 \%$ & $40 \mathrm{~mm}$ & G2 & Negative \\
\hline 9 & 84 & 2009 & + & $50 \%$ & + & $50 \%$ & $\begin{array}{c}38 \mathrm{~mm} \\
\sim 4\end{array}$ & G1 & Negative \\
\hline 10 & 85 & 2009 & + & $75 \%$ & + & $100 \%$ & $\begin{array}{c}17 \mathrm{~mm} \\
\sim 2\end{array}$ & G1 & Negative \\
\hline 11 & 87 & 2009 & + & $75 \%$ & + & $75 \%$ & $30 \mathrm{~mm}$ & G1 & Negative \\
\hline 12 & 39 & 2007 & + & $50 \%$ & - & $25 \%$ & $40 \mathrm{~mm}$ & G3 & Negative \\
\hline 13 & 50 & 2009 & + & $50 \%$ & - & $25 \%$ & $40 \mathrm{~mm}$ & G2 & Positive \\
\hline 14 & 58 & 2008 & + & $75 \%$ & - & $25 \%$ & $\begin{array}{c}38 \mathrm{~mm} \\
\sim 4\end{array}$ & G2 & Negative \\
\hline 15 & 60 & 2008 & + & $50 \%$ & - & 0 & $\begin{array}{c}19 \mathrm{~mm} \\
\sim 2 \\
\end{array}$ & G3 & Negative \\
\hline 16 & 63 & 2009 & + & $50 \%$ & - & 0 & $\begin{array}{c}55 \mathrm{~mm} \\
\sim 6\end{array}$ & G3 & Positive \\
\hline 17 & 69 & 2007 & + & $50 \%$ & - & $25 \%$ & $\begin{array}{c}23 \mathrm{~mm} \\
\sim 2\end{array}$ & G2 & Positive \\
\hline 18 & 69 & 2009 & + & $50 \%$ & - & 0 & $\begin{array}{c}27 \mathrm{~mm} \\
\sim 3\end{array}$ & G1 & Negative \\
\hline 19 & 79 & 2007 & + & $50 \%$ & - & 0 & $150 \mathrm{~mm}$ & G1 & Positive \\
\hline 20 & 81 & 2007 & ++ & $75 \%$ & - & 0 & $22 \mathrm{~mm}$ & G2 & Negative \\
\hline 21 & 77 & 2009 & - & 0 & ++ & $75 \%$ & $\begin{array}{c}25 \mathrm{~mm} \\
\sim 3\end{array}$ & G1 & Negative \\
\hline 22 & 81 & 2008 & - & $25 \%$ & ++ & $100 \%$ & $\begin{array}{c}18 \mathrm{~mm} \\
\sim 2\end{array}$ & G2 & Negative \\
\hline 23 & 91 & 2007 & - & $25 \%$ & ++ & $75 \%$ & $\begin{array}{c}23 \mathrm{~mm} \\
\sim 2\end{array}$ & G2 & Positive \\
\hline 24 & 59 & 2007 & - & $25 \%$ & - & 0 & $\begin{array}{c}15 \mathrm{~mm} \\
\sim 2\end{array}$ & G3 & Negative \\
\hline 25 & 70 & 2007 & - & $25 \%$ & - & 0 & $\begin{array}{c}19 \mathrm{~mm} \\
\sim 2\end{array}$ & G2 & Negative \\
\hline
\end{tabular}




\begin{tabular}{|c|c|c|c|c|c|c|c|c|c|}
\hline 26 & 70 & 2009 & - & $25 \%$ & - & 0 & $90 \mathrm{~mm}$ & G3 & Positive \\
\hline 27 & 71 & 2009 & - & $25 \%$ & - & 0 & $\begin{array}{c}75 \mathrm{~mm} \\
\sim 8\end{array}$ & G2 & Positive \\
\hline 28 & 73 & 2007 & - & $25 \%$ & - & 0 & $\begin{array}{c}14 \mathrm{~mm} \\
\sim 1\end{array}$ & G2 & Positive \\
\hline 29 & 78 & 2009 & - & $25 \%$ & - & 0 & $\begin{array}{c}35 \mathrm{~mm} \\
\sim 4\end{array}$ & G2 & Negative \\
\hline 30 & 79 & 2008 & - & $25 \%$ & - & 0 & $\begin{array}{c}55 \mathrm{~mm} \\
\sim 6\end{array}$ & G2 & Positive \\
\hline 31 & 81 & 2007 & - & 0 & - & 0 & $\begin{array}{c}65 \mathrm{~mm} \\
\sim\end{array}$ & G3 & Negative \\
\hline
\end{tabular}

Patients; Age; Year; COX-2 immunostaining; COX-2 expression; PR immunostaining; PR expression; Tumor size; Differentiation Grade; Axillary node metastasis 


\section{Annex 2}

\section{Correlation between Cyclooxigenase-2 Expression and Age}

\begin{tabular}{|r|l|r|r|r|}
\hline \multicolumn{2}{|c|}{ Ranks } \\
\hline \multirow{2}{*}{} & $\begin{array}{l}\text { COX-2 } \\
\text { status }\end{array}$ & N & Mean Rank & Sum of Ranks \\
\hline \multirow{2}{*}{ Age (yrs) } & Negative & 11 & 19,41 & 213,50 \\
\cline { 2 - 5 } & Positive & 20 & 14,13 & 282,50 \\
\cline { 2 - 5 } & Total & 31 & & \\
\hline
\end{tabular}

\begin{tabular}{|l|r|}
\hline \multicolumn{2}{|c|}{ Test Statistics ${ }^{\mathrm{b}}$} \\
\hline & \multicolumn{1}{c|}{ Age } \\
\hline Mann-Whitney U & 72,500 \\
\hline Wilcoxon W & 282,500 \\
\hline$Z$ & $-1,550$ \\
\hline Asymp. Sig. (2-tailed) &, 121 \\
\hline $\begin{array}{l}\text { Exact Sig. [2*(1-tailed } \\
\text { Sig.)] }\end{array}$ &, $123^{\mathrm{a}}$ \\
\hline a. Not corrected for ties. \\
\hline \begin{tabular}{l} 
b. Grouping Variable: COX-2 status \\
\hline
\end{tabular} \\
\hline
\end{tabular}

\begin{tabular}{|c|c|c|c|c|c|c|c|}
\hline \multicolumn{8}{|c|}{ Case Processing Summary } \\
\hline & \multirow{3}{*}{$\begin{array}{l}\text { Cox-2 } \\
\text { status }\end{array}$} & \multicolumn{6}{|c|}{ Cases } \\
\hline & & \multicolumn{2}{|c|}{ Valid } & \multicolumn{2}{|c|}{ Missing } & \multicolumn{2}{|c|}{ Total } \\
\hline & & $\mathrm{N}$ & Percent & $N$ & Percent & $N$ & Percent \\
\hline \multirow[t]{2}{*}{ Age (yrs) } & Negative & 11 & $100,0 \%$ & 0 & , $0 \%$ & 11 & $100,0 \%$ \\
\hline & Positive & 20 & $100,0 \%$ & 0 & , $0 \%$ & 20 & $100,0 \%$ \\
\hline
\end{tabular}




\begin{tabular}{|c|c|c|c|c|c|}
\hline \multicolumn{6}{|c|}{ Descriptives } \\
\hline & \multicolumn{3}{|c|}{ COX-2 status } & Statistic & Std. Error \\
\hline \multirow[t]{26}{*}{ Age (yrs) } & \multirow[t]{13}{*}{ Negative } & \multicolumn{2}{|l|}{ Mean } & 75,45 & 2,488 \\
\hline & & \multirow{2}{*}{$\begin{array}{l}95 \% \text { Confidence Interval } \\
\text { for Mean }\end{array}$} & Lower Bound & 69,91 & \\
\hline & & & Upper Bound & 81,00 & \\
\hline & & \multicolumn{2}{|l|}{$5 \%$ Trimmed Mean } & 75,51 & \\
\hline & & \multicolumn{2}{|l|}{ Median } & 77,00 & \\
\hline & & \multicolumn{2}{|l|}{ Variance } & 68,073 & \\
\hline & & \multicolumn{2}{|l|}{ Std. Deviation } & 8,251 & \\
\hline & & \multicolumn{2}{|l|}{ Minimum } & 59 & \\
\hline & & \multicolumn{2}{|l|}{ Maximum } & 91 & \\
\hline & & \multicolumn{2}{|l|}{ Range } & 32 & \\
\hline & & \multicolumn{2}{|l|}{\begin{tabular}{|l|} 
Interquartile Range \\
\end{tabular}} & 11 & \\
\hline & & \multicolumn{2}{|l|}{ Skewness } &,- 157 & ,661 \\
\hline & & \multicolumn{2}{|l|}{ Kurtosis } & 1,214 & 1,279 \\
\hline & \multirow[t]{13}{*}{ Positive } & \multicolumn{2}{|l|}{ Mean } & 65,65 & 3,584 \\
\hline & & \multirow{2}{*}{$\begin{array}{l}95 \% \text { Confidence Interval } \\
\text { for Mean }\end{array}$} & Lower Bound & 58,15 & \\
\hline & & & Upper Bound & 73,15 & \\
\hline & & \multicolumn{2}{|l|}{$5 \%$ Trimmed Mean } & 65,94 & \\
\hline & & \multicolumn{2}{|l|}{ Median } & 67,50 & \\
\hline & & \multicolumn{2}{|l|}{ Variance } & 256,871 & \\
\hline & & \multicolumn{2}{|l|}{ Std. Deviation } & 16,027 & \\
\hline & & \multicolumn{2}{|l|}{ Minimum } & 39 & \\
\hline & & \multicolumn{2}{|l|}{ Maximum } & 87 & \\
\hline & & \multicolumn{2}{|l|}{ Range } & 48 & \\
\hline & & \multicolumn{2}{|l|}{ Interquartile Range } & 29 & \\
\hline & & \multicolumn{2}{|l|}{ Skewness } &,- 346 &, 512 \\
\hline & & \multicolumn{2}{|l|}{ Kurtosis } & $-1,105$ & ,992 \\
\hline
\end{tabular}




\section{Annex 3}

Correlation between Cyclooxigenase-2 Expression and Tumor Size

\begin{tabular}{|l|l|r|r|r|}
\hline \multicolumn{3}{|c|}{ Ranks } \\
\hline & $\begin{array}{l}\text { COX-2 } \\
\text { status }\end{array}$ & N & Mean Rank & Sum of Ranks \\
\hline Tumor Size (cm) & Negative & 11 & 16,77 & 184,50 \\
\cline { 2 - 6 } & Positive & 20 & 15,58 & 311,50 \\
\cline { 2 - 6 } & Total & 31 & & \\
\hline
\end{tabular}

\begin{tabular}{|l|r|}
\hline \multicolumn{2}{|c|}{ Test Statistics $^{\mathrm{b}}$} \\
\hline & Tumor size \\
\hline Mann-Whitney U & 101,500 \\
\hline Wilcoxon W & 311,500 \\
\hline$Z$ &,- 352 \\
\hline Asymp. Sig. (2-tailed) &, 725 \\
\hline $\begin{array}{l}\text { Exact Sig. [2*(1-tailed } \\
\text { Sig.)] }\end{array}$ \\
\hline a. Not corrected for ties. \\
\hline b. Grouping Variable: COX-2 status \\
\hline
\end{tabular}

\begin{tabular}{|c|c|c|c|c|c|c|c|}
\hline \multicolumn{8}{|c|}{ Case Processing Summary } \\
\hline & \multirow{3}{*}{$\begin{array}{l}\text { COX-2 } \\
\text { status }\end{array}$} & \multicolumn{6}{|c|}{ Cases } \\
\hline & & \multicolumn{2}{|c|}{ Valid } & \multicolumn{2}{|c|}{ Missing } & \multicolumn{2}{|c|}{ Total } \\
\hline & & $N$ & Percent & $N$ & Percent & $\mathrm{N}$ & Percent \\
\hline \multirow[t]{2}{*}{ Tumor size $(\mathrm{cm})$} & Negative & 11 & $100,0 \%$ & 0 &, $0 \%$ & 11 & $100,0 \%$ \\
\hline & Positive & 20 & $100,0 \%$ & 0 &, $0 \%$ & 20 & $100,0 \%$ \\
\hline
\end{tabular}




\begin{tabular}{|c|c|c|c|c|c|}
\hline \multicolumn{6}{|c|}{ Descriptives } \\
\hline & \multicolumn{3}{|c|}{ COX-2 status } & Statistic & Std. Error \\
\hline \multirow[t]{26}{*}{ Tumor size $(\mathrm{cm})$} & \multirow[t]{13}{*}{ Negative } & \multicolumn{2}{|l|}{ Mean } & 3,95 & ,817 \\
\hline & & \multirow{2}{*}{$\begin{array}{l}95 \% \text { Confidence Interval } \\
\text { for Mean }\end{array}$} & Lower Bound & 2,13 & \\
\hline & & & Upper Bound & 5,77 & \\
\hline & & \multicolumn{2}{|l|}{ 5\% Trimmed Mean } & 3,81 & \\
\hline & & \multicolumn{2}{|l|}{ Median } & 2,50 & \\
\hline & & \multicolumn{2}{|l|}{ Variance } & 7,337 & \\
\hline & & \multicolumn{2}{|l|}{ Std. Deviation } & 2,709 & \\
\hline & & \multicolumn{2}{|l|}{ Minimum } & 1 & \\
\hline & & \multicolumn{2}{|l|}{ Maximum } & 9 & \\
\hline & & \multicolumn{2}{|l|}{ Range } & 8 & \\
\hline & & \multicolumn{2}{|l|}{ Interquartile Range } & 5 & \\
\hline & & \multicolumn{2}{|l|}{ Skewness } & ,845 & ,661 \\
\hline & & \multicolumn{2}{|l|}{ Kurtosis } &,- 798 & 1,279 \\
\hline & \multirow[t]{13}{*}{ Positive } & \multicolumn{2}{|l|}{ Mean } & 3,36 & ,660 \\
\hline & & \multirow{2}{*}{$\begin{array}{l}95 \% \text { Confidence Interval } \\
\text { for Mean }\end{array}$} & Lower Bound & 1,98 & \\
\hline & & & Upper Bound & 4,75 & \\
\hline & & \multicolumn{2}{|l|}{$5 \%$ Trimmed Mean } & 2,84 & \\
\hline & & \multicolumn{2}{|l|}{ Median } & 2,40 & \\
\hline & & \multicolumn{2}{|l|}{ Variance } & 8,715 & \\
\hline & & \multicolumn{2}{|l|}{ Std. Deviation } & 2,952 & \\
\hline & & \multicolumn{2}{|l|}{ Minimum } & 1 & \\
\hline & & \multicolumn{2}{|l|}{ Maximum } & 15 & \\
\hline & & \multicolumn{2}{|l|}{ Range } & 14 & \\
\hline & & \multicolumn{2}{|l|}{ Interquartile Range } & 2 & \\
\hline & & \multicolumn{2}{|l|}{ Skewness } & 3,517 &, 512 \\
\hline & & \multicolumn{2}{|l|}{ Kurtosis } & 13,973 & ,992 \\
\hline
\end{tabular}




\section{Annex 4}

Correlation between Cyclooxigenase-2 Expression and Tumor Size Group

\begin{tabular}{|c|c|c|c|c|c|c|}
\hline \multicolumn{7}{|c|}{ Case Processing Summary } \\
\hline & \multicolumn{6}{|c|}{ Cases } \\
\hline & \multicolumn{2}{|c|}{ Valid } & \multicolumn{2}{|c|}{ Missing } & \multicolumn{2}{|c|}{ Total } \\
\hline & $\mathrm{N}$ & Percent & $\mathrm{N}$ & Percent & $\mathrm{N}$ & Percent \\
\hline $\begin{array}{l}\text { COX-2 status * Tumor } \\
\text { size group }\end{array}$ & 31 & $100,0 \%$ & 0 &, $0 \%$ & 31 & $100,0 \%$ \\
\hline
\end{tabular}

\begin{tabular}{|c|c|c|c|c|c|}
\hline \multicolumn{6}{|c|}{ Crosstab } \\
\hline & & & \multicolumn{2}{|c|}{ Tumor size group } & \multirow[b]{2}{*}{ Total } \\
\hline & & & T1 & $\mathrm{T} 2+$ & \\
\hline \multirow[t]{8}{*}{ COX-2 status } & \multirow[t]{4}{*}{ Negative } & Count & 4 & 7 & 11 \\
\hline & & $\%$ within COX-2 status & $36,4 \%$ & $63,6 \%$ & $100,0 \%$ \\
\hline & & $\%$ within Tumor size group & $40,0 \%$ & $33,3 \%$ & $35,5 \%$ \\
\hline & & $\%$ of Total & $12,9 \%$ & $22,6 \%$ & $35,5 \%$ \\
\hline & \multirow[t]{4}{*}{ Positive } & Count & 6 & 14 & 20 \\
\hline & & $\%$ within COX-2 status & $30,0 \%$ & $70,0 \%$ & $100,0 \%$ \\
\hline & & $\%$ within Tumor size group & $60,0 \%$ & $66,7 \%$ & $64,5 \%$ \\
\hline & & $\%$ of Total & $19,4 \%$ & $45,2 \%$ & $64,5 \%$ \\
\hline \multirow{4}{*}{\multicolumn{2}{|c|}{ Total }} & Count & 10 & 21 & 31 \\
\hline & & $\%$ within COX-2 status & $32,3 \%$ & $67,7 \%$ & $100,0 \%$ \\
\hline & & $\%$ within Tumor size group & $100,0 \%$ & $100,0 \%$ & $100,0 \%$ \\
\hline & & $\%$ of Total & $32,3 \%$ & $67,7 \%$ & $100,0 \%$ \\
\hline
\end{tabular}




\begin{tabular}{|c|c|c|c|c|c|}
\hline \multicolumn{6}{|c|}{ Chi-Square Tests } \\
\hline & Value & $\mathrm{df}$ & $\begin{array}{c}\text { Asymp. Sig. (2- } \\
\text { sided) }\end{array}$ & $\begin{array}{c}\text { Exact Sig. (2- } \\
\text { sided) }\end{array}$ & $\begin{array}{c}\text { Exact Sig. (1- } \\
\text { sided) }\end{array}$ \\
\hline Pearson Chi-Square &, $132^{\mathrm{a}}$ & 1 & ,717 & & \\
\hline Continuity Correction ${ }^{\mathrm{b}}$ & ,000 & 1 & 1,000 & & \\
\hline Likelihood Ratio & , 130 & 1 & ,718 & & \\
\hline Fisher's Exact Test & & & & 1,000 &, 510 \\
\hline $\begin{array}{l}\text { Linear-by-Linear } \\
\text { Association }\end{array}$ & 127 & 1 & ,721 & & \\
\hline N of Valid Cases & 31 & & & & \\
\hline \multicolumn{6}{|c|}{ a. 1 cells $(25,0 \%)$ have expected count less than 5 . The minimum expected count is 3,55 . } \\
\hline b. Computed only for a & table & & & & \\
\hline
\end{tabular}

\begin{tabular}{|c|c|c|c|}
\hline \multicolumn{4}{|c|}{ Risk Estimate } \\
\hline & \multirow[b]{2}{*}{ Value } & \multicolumn{2}{|c|}{ 95\% Confidence Interval } \\
\hline & & Lower & Upper \\
\hline $\begin{array}{l}\text { Odds Ratio for COX-2 } \\
\text { status (Negative / } \\
\text { Positive) }\end{array}$ & 1,333 & ,281 & 6,325 \\
\hline $\begin{array}{l}\text { For cohort Tumor size } \\
\text { group = T1 }\end{array}$ & 1,212 & ,433 & 3,393 \\
\hline $\begin{array}{l}\text { For cohort Tumor size } \\
\text { group }=\mathrm{T} 2+\end{array}$ & ,909 &, 535 & 1,546 \\
\hline $\mathrm{N}$ of Valid Cases & 31 & & \\
\hline
\end{tabular}




\section{Annex 5}

Correlation between Cyclooxigenase- 2 expression and Differentiation Grade

\begin{tabular}{|c|c|c|c|c|c|c|}
\hline \multicolumn{7}{|c|}{ Case Processing Summary } \\
\hline & \multicolumn{6}{|c|}{ Cases } \\
\hline & \multicolumn{2}{|c|}{ Valid } & \multicolumn{2}{|c|}{ Missing } & \multicolumn{2}{|c|}{ Total } \\
\hline & $\mathrm{N}$ & Percent & $\mathrm{N}$ & Percent & $\mathrm{N}$ & Percent \\
\hline $\begin{array}{l}\text { COX-2 status }{ }^{*} \\
\text { Differentiation grade }\end{array}$ & 31 & $100,0 \%$ & 0 &, $0 \%$ & 31 & $100,0 \%$ \\
\hline
\end{tabular}

\begin{tabular}{|c|c|c|c|c|c|c|}
\hline \multicolumn{7}{|c|}{ Case Processing Summary } \\
\hline & \multicolumn{6}{|c|}{ Cases } \\
\hline & \multicolumn{2}{|c|}{ Valid } & \multicolumn{2}{|c|}{ Missing } & \multicolumn{2}{|c|}{ Total } \\
\hline & $\mathrm{N}$ & Percent & $\mathrm{N}$ & Percent & $\mathrm{N}$ & Percent \\
\hline $\begin{array}{l}\text { COX-2 status * } \\
\text { Differentiation grade }\end{array}$ & 31 & $100,0 \%$ & 0 &, $0 \%$ & 31 & $100,0 \%$ \\
\hline $\begin{array}{l}\text { COX-2 status }{ }^{*} \text { Axillary } \\
\text { node metastasis }\end{array}$ & 31 & $100,0 \%$ & 0 &, $0 \%$ & 31 & $100,0 \%$ \\
\hline
\end{tabular}

\begin{tabular}{|c|c|c|c|c|c|}
\hline \multicolumn{6}{|c|}{ Crosstab } \\
\hline & & & \multicolumn{2}{|c|}{ Differentiation grade } & \multirow[b]{2}{*}{ Total } \\
\hline & & & 1 & 2 or 3 & \\
\hline \multirow[t]{6}{*}{ COX-2 status } & \multirow[t]{4}{*}{ Negative } & Count & 1 & 10 & 11 \\
\hline & & $\%$ within COX-2 status & $9,1 \%$ & $90,9 \%$ & $100,0 \%$ \\
\hline & & $\begin{array}{l}\text { \% within Differentiation } \\
\text { grade }\end{array}$ & $14,3 \%$ & $41,7 \%$ & $35,5 \%$ \\
\hline & & $\%$ of Total & $3,2 \%$ & $32,3 \%$ & $35,5 \%$ \\
\hline & \multirow[t]{2}{*}{ Positive } & Count & 6 & 14 & 20 \\
\hline & & $\%$ within COX-2 status & $30,0 \%$ & $70,0 \%$ & $100,0 \%$ \\
\hline
\end{tabular}




\begin{tabular}{|c|c|c|c|c|}
\hline & $\begin{array}{l}\% \text { within Differentiation } \\
\text { grade }\end{array}$ & $85,7 \%$ & $58,3 \%$ & $64,5 \%$ \\
\hline & $\%$ of Total & $19,4 \%$ & $45,2 \%$ & $64,5 \%$ \\
\hline \multirow[t]{4}{*}{ Total } & Count & 7 & 24 & 31 \\
\hline & $\%$ within COX-2 status & $22,6 \%$ & $77,4 \%$ & $100,0 \%$ \\
\hline & $\begin{array}{l}\% \text { within Differentiation } \\
\text { grade }\end{array}$ & $100,0 \%$ & $100,0 \%$ & $100,0 \%$ \\
\hline & $\%$ of Total & $22,6 \%$ & $77,4 \%$ & $100,0 \%$ \\
\hline
\end{tabular}

\begin{tabular}{|c|c|c|c|c|c|}
\hline \multicolumn{6}{|c|}{ Chi-Square Tests } \\
\hline & Value & $\mathrm{df}$ & $\begin{array}{c}\text { Asymp. Sig. (2- } \\
\text { sided) }\end{array}$ & $\begin{array}{c}\text { Exact Sig. (2- } \\
\text { sided) }\end{array}$ & $\begin{array}{l}\text { Exact Sig. (1- } \\
\text { sided) }\end{array}$ \\
\hline Pearson Chi-Square & $1,775^{\mathrm{a}}$ & 1 & , 183 & & \\
\hline Continuity Correction ${ }^{\mathrm{b}}$ & ,780 & 1 &, 377 & & \\
\hline Likelihood Ratio & 1,981 & 1 & , 159 & & \\
\hline Fisher's Exact Test & & & & ,372 & ,192 \\
\hline $\begin{array}{l}\text { Linear-by-Linear } \\
\text { Association }\end{array}$ & 1,718 & 1 & , 190 & & \\
\hline $\mathrm{N}$ of Valid Cases & 31 & & & & \\
\hline \multicolumn{6}{|c|}{ a. 2 cells $(50,0 \%)$ have expected count less than 5 . The minimum expected count is 2,48 . } \\
\hline \multicolumn{6}{|c|}{ b. Computed only for a $2 \times 2$ table } \\
\hline
\end{tabular}

\begin{tabular}{|c|c|c|c|}
\hline \multicolumn{4}{|c|}{ Risk Estimate } \\
\hline & \multirow[b]{2}{*}{ Value } & \multicolumn{2}{|c|}{ 95\% Confidence Interval } \\
\hline & & Lower & Upper \\
\hline $\begin{array}{l}\text { Odds Ratio for COX-2 } \\
\text { status (Negative / } \\
\text { Positive) }\end{array}$ & ,233 & ,024 & 2,252 \\
\hline $\begin{array}{l}\text { For cohort Differentiation } \\
\text { grade }=1\end{array}$ & ,303 &, 042 & 2,206 \\
\hline $\begin{array}{l}\text { For cohort Differentiation } \\
\text { grade }=2 \text { ou } 3\end{array}$ & 1,299 & ,922 & 1,829 \\
\hline N of Valid Cases & 31 & & \\
\hline
\end{tabular}




\section{Annex 6}

Correlation between Cyclooxigenase-2 Expression and Axillary Node Metastasis

\begin{tabular}{|c|c|c|c|c|c|c|}
\hline \multicolumn{7}{|c|}{ Case Processing Summary } \\
\hline & \multicolumn{6}{|c|}{ Cases } \\
\hline & \multicolumn{2}{|c|}{ Valid } & \multicolumn{2}{|c|}{ Missing } & \multicolumn{2}{|c|}{ Total } \\
\hline & $\mathrm{N}$ & Percent & $\mathrm{N}$ & Percent & $\mathrm{N}$ & Percent \\
\hline $\begin{array}{l}\text { COX-2 status * Axillary } \\
\text { node metastasis }\end{array}$ & 31 & $100,0 \%$ & 0 &, $0 \%$ & 31 & $100,0 \%$ \\
\hline
\end{tabular}

\begin{tabular}{|c|c|c|c|c|c|}
\hline \multicolumn{6}{|c|}{ Crosstab } \\
\hline & & & \multicolumn{2}{|c|}{ Ganglion metastasis } & \multirow[b]{2}{*}{ Total } \\
\hline & & & No & Yes & \\
\hline \multirow{8}{*}{$\begin{array}{l}\text { COX-2 } \\
\text { status }\end{array}$} & \multirow[t]{4}{*}{ Negative } & Count & 6 & 5 & 11 \\
\hline & & $\%$ within COX-2 status & $54,5 \%$ & $45,5 \%$ & $100,0 \%$ \\
\hline & & $\begin{array}{l}\% \text { within Ganglion } \\
\text { metastasis }\end{array}$ & $27,3 \%$ & $55,6 \%$ & $35,5 \%$ \\
\hline & & $\%$ of Total & $19,4 \%$ & $16,1 \%$ & $35,5 \%$ \\
\hline & \multirow[t]{4}{*}{ Positive } & Count & 16 & 4 & 20 \\
\hline & & $\%$ within COX-2 status & $80,0 \%$ & $20,0 \%$ & $100,0 \%$ \\
\hline & & $\begin{array}{l}\% \text { within Ganglion } \\
\text { metastasis }\end{array}$ & $72,7 \%$ & $44,4 \%$ & $64,5 \%$ \\
\hline & & $\%$ of Total & $51,6 \%$ & $12,9 \%$ & $64,5 \%$ \\
\hline \multirow[t]{4}{*}{ Total } & & Count & 22 & 9 & 31 \\
\hline & & $\%$ within COX-2 status & $71,0 \%$ & $29,0 \%$ & $100,0 \%$ \\
\hline & & $\begin{array}{l}\% \text { within Ganglion } \\
\text { metastasis }\end{array}$ & $100,0 \%$ & $100,0 \%$ & $100,0 \%$ \\
\hline & & $\%$ of Total & $71,0 \%$ & $29,0 \%$ & $100,0 \%$ \\
\hline
\end{tabular}




\begin{tabular}{|c|c|c|c|c|c|}
\hline \multicolumn{6}{|c|}{ Chi-Square Tests } \\
\hline & Value & $\mathrm{df}$ & $\begin{array}{c}\text { Asymp. Sig. (2- } \\
\text { sided) }\end{array}$ & $\begin{array}{c}\text { Exact Sig. (2- } \\
\text { sided) }\end{array}$ & $\begin{array}{c}\text { Exact Sig. (1- } \\
\text { sided) }\end{array}$ \\
\hline Pearson Chi-Square & $2,232^{\mathrm{a}}$ & 1 & 135 & & \\
\hline Continuity Correction ${ }^{\mathrm{b}}$ & 1,167 & 1 & ,280 & & \\
\hline Likelihood Ratio & 2,177 & 1 & 140 & & \\
\hline Fisher's Exact Test & & & & ,217 & , 140 \\
\hline $\begin{array}{l}\text { Linear-by-Linear } \\
\text { Association }\end{array}$ & 2,160 & 1 & ,142 & & \\
\hline N of Valid Cases & 31 & & & & \\
\hline \multicolumn{6}{|c|}{ a. 1 cells $(25,0 \%)$ have expected count less than 5 . The minimum expected count is 3,19 . } \\
\hline b. Computed only for a & table & & & & \\
\hline
\end{tabular}

\begin{tabular}{|c|c|c|c|}
\hline \multicolumn{4}{|c|}{ Risk Estimate } \\
\hline & \multirow[b]{2}{*}{ Value } & \multicolumn{2}{|c|}{ 95\% Confidence Interval } \\
\hline & & Lower & Upper \\
\hline $\begin{array}{l}\text { Odds Ratio for COX-2 } \\
\text { status (Negative / } \\
\text { Positive) }\end{array}$ & ,300 &, 060 & 1,509 \\
\hline $\begin{array}{l}\text { For cohort Ganglion } \\
\text { metastasis = No }\end{array}$ & ,682 & ,381 & 1,221 \\
\hline $\begin{array}{l}\text { For cohort Ganglion } \\
\text { metastasis = yes }\end{array}$ & 2,273 & ,764 & 6,757 \\
\hline N of Valid Cases & 31 & & \\
\hline
\end{tabular}




\section{Annex 7}

\section{Correlation between Progesterone Receptor Expression and Age}

\begin{tabular}{|l|l|r|r|r|}
\hline \multicolumn{5}{|c|}{ Ranks } \\
\hline & PR status & \multicolumn{1}{|c|}{ N } & Mean Rank & Sum of Ranks \\
\hline \multirow{3}{*}{ Age (yrs) } & Negative & 17 & 14,15 & 240,50 \\
\cline { 2 - 6 } & Positive & 14 & 18,25 & 255,50 \\
\cline { 2 - 5 } & Total & 31 & & \\
\hline
\end{tabular}

\begin{tabular}{|l|r|}
\hline \multicolumn{2}{|c|}{ Test Statistics $^{\mathrm{b}}$} \\
\hline & \multicolumn{2}{|c|}{ Age } \\
\hline Mann-Whitney U & 87,500 \\
\hline Wilcoxon W & 240,500 \\
\hline$Z$ & $-1,252$ \\
\hline Asymp. Sig. (2-tailed) &, 211 \\
\hline $\begin{array}{l}\text { Exact Sig. [2*(1-tailed } \\
\text { Sig.)] }\end{array}$ &, $215^{\mathrm{a}}$ \\
\hline a. Not corrected for ties. \\
\hline b. Grouping Variable: 4. Rp \% \\
\hline
\end{tabular}

\begin{tabular}{|c|c|c|c|c|c|c|c|}
\hline \multicolumn{8}{|c|}{ Case Processing Summary } \\
\hline & \multirow[b]{3}{*}{ PR status } & \multicolumn{6}{|c|}{ Cases } \\
\hline & & \multicolumn{2}{|c|}{ Valid } & \multicolumn{2}{|c|}{ Missing } & \multicolumn{2}{|c|}{ Total } \\
\hline & & $\mathrm{N}$ & Percent & $\mathrm{N}$ & Percent & $\mathrm{N}$ & Percent \\
\hline \multirow[t]{2}{*}{ Age (yrs) } & Negative & 17 & $100,0 \%$ & 0 & $0 \%$ & 17 & $100,0 \%$ \\
\hline & Positive & 14 & $100,0 \%$ & 0 &, $0 \%$ & 14 & $100,0 \%$ \\
\hline
\end{tabular}




\begin{tabular}{|c|c|c|c|c|c|c|c|}
\hline \multicolumn{8}{|c|}{ Case Processing Summary } \\
\hline & \multirow[b]{3}{*}{ PR status } & \multicolumn{6}{|c|}{ Cases } \\
\hline & & \multicolumn{2}{|c|}{ Valid } & \multicolumn{2}{|c|}{ Missing } & \multicolumn{2}{|c|}{ Total } \\
\hline & & $N$ & Percent & $\mathrm{N}$ & Percent & $\mathrm{N}$ & Percent \\
\hline \multirow[t]{2}{*}{ Tumor size $(\mathrm{cm})$} & Negative & 17 & $100,0 \%$ & 0 & ,0\% & 17 & $100,0 \%$ \\
\hline & Positive & 14 & $100,0 \%$ & 0 &, $0 \%$ & 14 & $100,0 \%$ \\
\hline
\end{tabular}

\begin{tabular}{|c|c|c|c|c|c|}
\hline \multicolumn{6}{|c|}{ Descriptives } \\
\hline & PR status & & & Statistic & Std. Error \\
\hline \multirow[t]{26}{*}{ Age (yrs) } & \multirow[t]{13}{*}{ Negative } & \multicolumn{2}{|l|}{ Mean } & 67,59 & 2,815 \\
\hline & & \multirow{2}{*}{$\begin{array}{l}95 \% \text { Confidence Interval } \\
\text { for Mean }\end{array}$} & Lower Bound & 61,62 & \\
\hline & & & Upper Bound & 73,56 & \\
\hline & & \multicolumn{2}{|l|}{ 5\% Trimmed Mean } & 68,43 & \\
\hline & & \multicolumn{2}{|l|}{ Median } & 70,00 & \\
\hline & & \multicolumn{2}{|l|}{ Variance } & 134,757 & \\
\hline & & \multicolumn{2}{|l|}{ Std. Deviation } & 11,609 & \\
\hline & & \multicolumn{2}{|l|}{ Minimum } & 39 & \\
\hline & & \multicolumn{2}{|l|}{ Maximum } & 81 & \\
\hline & & \multicolumn{2}{|l|}{ Range } & 42 & \\
\hline & & \multicolumn{2}{|l|}{ Interquartile Range } & 19 & \\
\hline & & \multicolumn{2}{|l|}{ Skewness } &,- 982 &, 550 \\
\hline & & \multicolumn{2}{|l|}{ Kurtosis } &, 820 & 1,063 \\
\hline & \multirow[t]{13}{*}{ Positive } & \multicolumn{2}{|l|}{ Mean } & 71,00 & 4,687 \\
\hline & & \multirow{2}{*}{$\begin{array}{l}95 \% \text { Confidence Interval } \\
\text { for Mean }\end{array}$} & Lower Bound & 60,87 & \\
\hline & & & Upper Bound & 81,13 & \\
\hline & & \multicolumn{2}{|l|}{ 5\% Trimmed Mean } & 71,67 & \\
\hline & & \multicolumn{2}{|l|}{ Median } & 78,50 & \\
\hline & & \multicolumn{2}{|l|}{ Variance } & 307,538 & \\
\hline & & \multicolumn{2}{|l|}{ Std. Deviation } & 17,537 & \\
\hline & & \multicolumn{2}{|l|}{ Minimum } & 39 & \\
\hline & & \multicolumn{2}{|l|}{ Maximum } & 91 & \\
\hline & & \multicolumn{2}{|l|}{ Range } & 52 & \\
\hline & & \multicolumn{2}{|l|}{ Interquartile Range } & 27 & \\
\hline & & \multicolumn{2}{|l|}{ Skewness } &,- 865 & ,597 \\
\hline & & \multicolumn{2}{|l|}{ Kurtosis } &,- 650 & 1,154 \\
\hline
\end{tabular}




\section{Annex 8}

Correlation between Progesterone Receptor Expression and Tumor Size

\begin{tabular}{|l|l|r|r|r|}
\hline \multicolumn{5}{|c|}{ Ranks } \\
\hline & PR status & \multicolumn{1}{|c|}{ N } & Mean Rank & Sum of Ranks \\
\hline \multirow{3}{*}{ Tumor size $(\mathrm{cm})$} & Negative & 17 & 19,18 & 326,00 \\
\cline { 2 - 6 } & Positive & 14 & 12,14 & 170,00 \\
\cline { 2 - 5 } & Total & 31 & & \\
\hline
\end{tabular}

\begin{tabular}{|l|r|}
\hline \multicolumn{2}{|c|}{ Test Statistics $^{\mathrm{b}}$} \\
\hline & \multicolumn{1}{|c|}{ Tumor size } \\
\hline Mann-Whitney U & 65,000 \\
\hline Wilcoxon W & 170,000 \\
\hline$Z$ &, 032 \\
\hline Asymp. Sig. (2-tailed) &, $032^{\mathrm{a}}$ \\
\hline Exact Sig. [2*(1-tailed \\
Sig.)]
\end{tabular}

\begin{tabular}{|c|c|c|c|c|c|c|c|}
\hline \multicolumn{8}{|c|}{ Case Processing Summary } \\
\hline & \multirow[b]{3}{*}{ PR status } & \multicolumn{6}{|c|}{ Cases } \\
\hline & & \multicolumn{2}{|c|}{ Valid } & \multicolumn{2}{|c|}{ Missing } & \multicolumn{2}{|c|}{ Total } \\
\hline & & $\mathrm{N}$ & Percent & $\mathrm{N}$ & Percent & $\mathrm{N}$ & Percent \\
\hline \multirow[t]{2}{*}{ Tumor size $(\mathrm{cm})$} & Negative & 17 & $100,0 \%$ & 0 & ,0\% & 17 & $100,0 \%$ \\
\hline & Positive & 14 & $100,0 \%$ & 0 & ,0\% & 14 & $100,0 \%$ \\
\hline
\end{tabular}




\begin{tabular}{|c|c|c|c|c|c|}
\hline \multicolumn{6}{|c|}{ Descriptives } \\
\hline & \multicolumn{3}{|l|}{ PR status } & Statistic & Std. Error \\
\hline \multirow{26}{*}{$\begin{array}{l}\text { Tumor size } \\
(\mathrm{cm})\end{array}$} & \multirow[t]{13}{*}{ Negative } & \multicolumn{2}{|l|}{ Mean } & 4,60 & ,842 \\
\hline & & \multirow{2}{*}{$\begin{array}{l}95 \% \text { Confidence Interval } \\
\text { for Mean }\end{array}$} & Lower Bound & 2,82 & \\
\hline & & & Upper Bound & 6,38 & \\
\hline & & \multicolumn{2}{|l|}{ 5\% Trimmed Mean } & 4,20 & \\
\hline & & \multicolumn{2}{|l|}{ Median } & 3,80 & \\
\hline & & \multicolumn{2}{|l|}{ Variance } & 12,051 & \\
\hline & & \multicolumn{2}{|l|}{ Std. Deviation } & 3,471 & \\
\hline & & \multicolumn{2}{|l|}{ Minimum } & 1 & \\
\hline & & \multicolumn{2}{|l|}{ Maximum } & 15 & \\
\hline & & \multicolumn{2}{|l|}{ Range } & 14 & \\
\hline & & \multicolumn{2}{|l|}{ Interquartile Range } & 4 & \\
\hline & & \multicolumn{2}{|l|}{ Skewness } & 1,872 &, 550 \\
\hline & & \multicolumn{2}{|l|}{ Kurtosis } & 4,205 & 1,063 \\
\hline & \multirow[t]{13}{*}{ Positive } & \multicolumn{2}{|l|}{ Mean } & 2,32 & ,218 \\
\hline & & \multirow{2}{*}{$\begin{array}{l}95 \% \text { Confidence Interval } \\
\text { for Mean }\end{array}$} & Lower Bound & 1,85 & \\
\hline & & & Upper Bound & 2,79 & \\
\hline & & \multicolumn{2}{|l|}{ 5\% Trimmed Mean } & 2,29 & \\
\hline & & \multicolumn{2}{|l|}{ Median } & 2,30 & \\
\hline & & \multicolumn{2}{|l|}{ Variance } & ,666 & \\
\hline & & \multicolumn{2}{|l|}{ Std. Deviation } & ,816 & \\
\hline & & \multicolumn{2}{|l|}{ Minimum } & 1 & \\
\hline & & \multicolumn{2}{|l|}{ Maximum } & 4 & \\
\hline & & \multicolumn{2}{|l|}{ Range } & 3 & \\
\hline & & \multicolumn{2}{|l|}{ Interquartile Range } & 1 & \\
\hline & & \multicolumn{2}{|l|}{ Skewness } &, 935 & ,597 \\
\hline & & \multicolumn{2}{|l|}{ Kurtosis } &, 378 & 1,154 \\
\hline
\end{tabular}




\section{Annex 9}

Correlation between Progesterone Receptor Expression and Differentiation Grade

\begin{tabular}{|c|c|c|c|c|c|c|}
\hline \multicolumn{7}{|c|}{ Case Processing Summary } \\
\hline & \multicolumn{6}{|c|}{ Cases } \\
\hline & \multicolumn{2}{|c|}{ Valid } & \multicolumn{2}{|c|}{ Missing } & \multicolumn{2}{|c|}{ Total } \\
\hline & $\mathrm{N}$ & Percent & $\mathrm{N}$ & Percent & $\mathrm{N}$ & Percent \\
\hline $\begin{array}{l}\text { PR status * } \\
\text { Differentiation grade }\end{array}$ & 31 & $100,0 \%$ & 0 &, $0 \%$ & 31 & $100,0 \%$ \\
\hline
\end{tabular}

\begin{tabular}{|c|c|c|c|c|c|}
\hline \multicolumn{6}{|c|}{ Crosstab } \\
\hline & & & \multicolumn{2}{|c|}{ Differentiation grade } & \multirow[b]{2}{*}{ Total } \\
\hline & & & 1 & 2 or 3 & \\
\hline \multirow[t]{8}{*}{ PR status } & \multirow[t]{4}{*}{ Negative } & Count & 2 & 15 & 17 \\
\hline & & $\%$ within PR status & $11,8 \%$ & $88,2 \%$ & $100,0 \%$ \\
\hline & & $\begin{array}{c}\% \text { within Differentiation } \\
\text { grade }\end{array}$ & $28,6 \%$ & $62,5 \%$ & $54,8 \%$ \\
\hline & & $\%$ of Total & $6,5 \%$ & $48,4 \%$ & $54,8 \%$ \\
\hline & \multirow[t]{4}{*}{ Positive } & Count & 5 & 9 & 14 \\
\hline & & $\%$ within PR status & $35,7 \%$ & $64,3 \%$ & $100,0 \%$ \\
\hline & & $\begin{array}{c}\% \text { within Differentiation } \\
\text { grade }\end{array}$ & $71,4 \%$ & $37,5 \%$ & $45,2 \%$ \\
\hline & & $\%$ of Total & $16,1 \%$ & $29,0 \%$ & $45,2 \%$ \\
\hline \multirow{4}{*}{\multicolumn{2}{|c|}{ Total }} & Count & 7 & 24 & 31 \\
\hline & & $\%$ within PR status & $22,6 \%$ & $77,4 \%$ & $100,0 \%$ \\
\hline & & $\begin{array}{c}\% \text { within Differentiation } \\
\text { grade }\end{array}$ & $100,0 \%$ & $100,0 \%$ & $100,0 \%$ \\
\hline & & $\%$ of Total & $22,6 \%$ & $77,4 \%$ & $100,0 \%$ \\
\hline
\end{tabular}




\begin{tabular}{|c|c|c|c|c|c|}
\hline \multicolumn{6}{|c|}{ Chi-Square Tests } \\
\hline & Value & $\mathrm{df}$ & $\begin{array}{c}\text { Asymp. Sig. (2- } \\
\text { sided) }\end{array}$ & $\begin{array}{c}\text { Exact Sig. (2- } \\
\text { sided) }\end{array}$ & $\begin{array}{c}\text { Exact Sig. (1- } \\
\text { sided) }\end{array}$ \\
\hline Pearson Chi-Square & $2,519^{\mathrm{a}}$ & 1 & ,112 & & \\
\hline Continuity Correction ${ }^{\mathrm{b}}$ & 1,335 & 1 & ,248 & & \\
\hline Likelihood Ratio & 2,554 & 1 & ,110 & & \\
\hline Fisher's Exact Test & & & & ,198 & ,124 \\
\hline $\begin{array}{l}\text { Linear-by-Linear } \\
\text { Association }\end{array}$ & 2,438 & 1 & ,118 & & \\
\hline N of Valid Cases & 31 & & & & \\
\hline \multicolumn{6}{|c|}{ a. 2 cells $(50,0 \%)$ have expected count less than 5 . The minimum expected count is 3,16 . } \\
\hline b. Computed only for a & table & & & & \\
\hline
\end{tabular}

\begin{tabular}{|c|c|c|c|}
\hline \multicolumn{4}{|c|}{ Risk Estimate } \\
\hline & \multirow[b]{2}{*}{ Value } & \multicolumn{2}{|c|}{ 95\% Confidence Interval } \\
\hline & & Lower & Upper \\
\hline $\begin{array}{l}\text { Odds Ratio for PR status } \\
\text { (Negative / Positive) }\end{array}$ & ,240 & ,038 & 1,506 \\
\hline $\begin{array}{l}\text { For cohort Differentiation } \\
\text { grade }=1\end{array}$ & ,329 & ,075 & 1,446 \\
\hline $\begin{array}{l}\text { For cohort Differentiation } \\
\text { grade }=2 \text { ou } 3\end{array}$ & 1,373 & ,895 & 2,104 \\
\hline$N$ of Valid Cases & 31 & & \\
\hline
\end{tabular}




\section{Annex 10}

Correlation between Progesterone Receptor Expression and Axillary Node Metastasis

\begin{tabular}{|c|c|c|c|c|c|c|}
\hline \multicolumn{7}{|c|}{ Case Processing Summary } \\
\hline & \multicolumn{6}{|c|}{ Cases } \\
\hline & \multicolumn{2}{|c|}{ Valid } & \multicolumn{2}{|c|}{ Missing } & \multicolumn{2}{|c|}{ Total } \\
\hline & $\mathrm{N}$ & Percent & $\mathrm{N}$ & Percent & $\mathrm{N}$ & Percent \\
\hline $\begin{array}{l}\text { PR status * Axillary node } \\
\text { metastasis }\end{array}$ & 31 & $100,0 \%$ & 0 &, $0 \%$ & 31 & $100,0 \%$ \\
\hline
\end{tabular}

\begin{tabular}{|c|c|c|c|c|c|}
\hline \multicolumn{6}{|c|}{ Crosstab } \\
\hline & & & \multicolumn{2}{|c|}{$\begin{array}{c}\text { Axillary node } \\
\text { metastasis }\end{array}$} & \multirow[b]{2}{*}{ Total } \\
\hline & & & No & Yes & \\
\hline \multirow[t]{8}{*}{ PR status } & \multirow[t]{4}{*}{ Negative } & Count & 9 & 8 & 17 \\
\hline & & $\%$ within PR status & $52,9 \%$ & $47,1 \%$ & $100,0 \%$ \\
\hline & & $\begin{array}{l}\% \text { within Ganglion } \\
\text { metastasis }\end{array}$ & $40,9 \%$ & $88,9 \%$ & $54,8 \%$ \\
\hline & & $\%$ of Total & $29,0 \%$ & $25,8 \%$ & $54,8 \%$ \\
\hline & \multirow[t]{4}{*}{ Positive } & Count & 13 & 1 & 14 \\
\hline & & $\%$ within PR status & $92,9 \%$ & $7,1 \%$ & $100,0 \%$ \\
\hline & & $\begin{array}{l}\% \text { within Ganglion } \\
\text { metastasis }\end{array}$ & $59,1 \%$ & $11,1 \%$ & $45,2 \%$ \\
\hline & & $\%$ of Total & $41,9 \%$ & $3,2 \%$ & $45,2 \%$ \\
\hline \multirow{4}{*}{\multicolumn{2}{|c|}{ Total }} & Count & 22 & 9 & 31 \\
\hline & & $\%$ within PR status & $71,0 \%$ & $29,0 \%$ & $100,0 \%$ \\
\hline & & $\begin{array}{l}\% \text { within Ganglion } \\
\text { metastasis }\end{array}$ & $100,0 \%$ & $100,0 \%$ & $100,0 \%$ \\
\hline & & $\%$ of Total & $71,0 \%$ & $29,0 \%$ & $100,0 \%$ \\
\hline
\end{tabular}




\begin{tabular}{|c|c|c|c|c|c|}
\hline \multicolumn{6}{|c|}{ Chi-Square Tests } \\
\hline & Value & $\mathrm{df}$ & $\begin{array}{c}\text { Asymp. Sig. (2- } \\
\text { sided) }\end{array}$ & $\begin{array}{c}\text { Exact Sig. (2- } \\
\text { sided) }\end{array}$ & $\begin{array}{c}\text { Exact Sig. (1- } \\
\text { sided) }\end{array}$ \\
\hline Pearson Chi-Square & $5,937^{\mathrm{a}}$ & 1 & 015 & & \\
\hline Continuity Correction ${ }^{\mathrm{b}}$ & 4,158 & 1 & 041 & & \\
\hline Likelihood Ratio & 6,638 & 1 & 010 & & \\
\hline Fisher's Exact Test & & & & 021 & ,018 \\
\hline $\begin{array}{l}\text { Linear-by-Linear } \\
\text { Association }\end{array}$ & 5,745 & 1 & 017 & & \\
\hline N of Valid Cases & 31 & & & & \\
\hline \multicolumn{6}{|c|}{ a. 2 cells $(50,0 \%)$ have expected count less than 5 . The minimum expected count is 4,06 . } \\
\hline b. Computed only for a & table & & & & \\
\hline
\end{tabular}

\begin{tabular}{|l|r|r|c|}
\hline \multicolumn{4}{|c|}{ Risk Estimate } \\
\cline { 1 - 1 } & \multicolumn{2}{|c|}{ Value } & \multicolumn{2}{|c|}{ Low Confidence Interval } \\
\cline { 5 - 5 } &, 087 &, 009 & Upper \\
\hline $\begin{array}{l}\text { Odds Ratio for PR status } \\
\text { (Negative / Positive) }\end{array}$ &, 570 &, 356 &, 913 \\
\hline $\begin{array}{l}\text { For cohort Ganglion } \\
\text { metastasis = No }\end{array}$ & 6,588 &, 933 & 46,530 \\
\hline $\begin{array}{l}\text { For cohort Ganglion } \\
\text { metastasis = Yes }\end{array}$ & 31 & & \\
\hline N of Valid Cases & & & \\
\hline
\end{tabular}




\section{Annex 11}

Correlation between Progesterone Receptor Expression and Age according to Cyclooxygenase-2 Expression

\begin{tabular}{|l|l|l|r|r|r|}
\hline \multicolumn{7}{|c|}{ Ranks } \\
\hline COX-2 status & PR status & $\mathrm{N}$ & Mean Rank & Sum of Ranks \\
\hline \multirow{2}{*}{ Negative } & Age (yrs) & Negative & 8 & 4,94 & 39,50 \\
\cline { 3 - 7 } & & Positive & 3 & 8,83 & 26,50 \\
\cline { 3 - 7 } & & Total & 11 & & \\
\hline \multirow{2}{*}{ Positive } & \multirow{2}{*}{ Age (yrs) } & Negative & 9 & 9,06 & 81,50 \\
\cline { 3 - 7 } & & Positive & 11 & 11,68 & 128,50 \\
\cline { 3 - 7 } & & Total & 20 & & \\
\hline
\end{tabular}

\begin{tabular}{|c|c|c|}
\hline \multicolumn{3}{|c|}{ Test Statistics $^{\mathrm{b}}$} \\
\hline \multicolumn{2}{|c|}{ COX-2 status } & \multirow[t]{2}{*}{ Age (yrs) } \\
\hline Negative & Mann-Whitney U & \\
\hline & Wilcoxon W & 39,500 \\
\hline & Z & $-1,743$ \\
\hline & Asymp. Sig. (2-tailed) & 081 \\
\hline & $\begin{array}{l}\text { Exact Sig. [2* }(1-\text { tailed } \\
\text { Sig. })]\end{array}$ &, $085^{\mathrm{a}}$ \\
\hline \multirow[t]{5}{*}{ Positive } & Mann-Whitney U & 36,500 \\
\hline & Wilcoxon W & 81,500 \\
\hline & Z &,- 989 \\
\hline & Asymp. Sig. (2-tailed) & ,323 \\
\hline & $\begin{array}{l}\text { Exact Sig. [2* }(1 \text {-tailed } \\
\text { Sig. })]\end{array}$ &, $331^{\mathrm{a}}$ \\
\hline \multicolumn{3}{|c|}{ a. Not corrected for ties. } \\
\hline \multicolumn{3}{|c|}{ b. Grouping Variable: 4. Rp \% } \\
\hline
\end{tabular}




\begin{tabular}{|c|c|c|c|c|c|c|c|c|}
\hline \multicolumn{9}{|c|}{ Case Processing Summary } \\
\hline & & \multirow[b]{3}{*}{ RP status } & \multicolumn{6}{|c|}{ Cases } \\
\hline & & & \multicolumn{2}{|c|}{ Valid } & \multicolumn{2}{|c|}{ Missing } & \multicolumn{2}{|c|}{ Total } \\
\hline \multicolumn{2}{|c|}{ COX-2 status } & & $\mathrm{N}$ & Percent & $\mathrm{N}$ & Percent & $\mathrm{N}$ & Percent \\
\hline \multirow[t]{2}{*}{ Negative } & \multirow[t]{2}{*}{ Age (yrs) } & Negative & 8 & $100,0 \%$ & 0 &, $0 \%$ & 8 & $100,0 \%$ \\
\hline & & Positive & 3 & $100,0 \%$ & 0 &, $0 \%$ & 3 & $100,0 \%$ \\
\hline \multirow[t]{2}{*}{ Positive } & \multirow[t]{2}{*}{ Age (yrs) } & Negative & 9 & $100,0 \%$ & 0 &, $0 \%$ & 9 & $100,0 \%$ \\
\hline & & Positive & 11 & $100,0 \%$ & 0 &, $0 \%$ & 11 & $100,0 \%$ \\
\hline
\end{tabular}

\begin{tabular}{|c|c|c|c|c|c|c|}
\hline \multicolumn{7}{|c|}{ Descriptives } \\
\hline \multicolumn{2}{|c|}{ COX-2 status } & \multicolumn{3}{|l|}{ PR status } & Statistic & Std. Error \\
\hline \multirow[t]{24}{*}{ Negative } & \multirow[t]{24}{*}{ Age (yrs) } & \multirow[t]{13}{*}{ Negative } & \multicolumn{2}{|l|}{ Mean } & 72,63 & 2,471 \\
\hline & & & \multirow{2}{*}{$\begin{array}{l}95 \% \text { Confidence Interval } \\
\text { for Mean }\end{array}$} & Lower Bound & 66,78 & \\
\hline & & & & Upper Bound & 78,47 & \\
\hline & & & \multicolumn{2}{|l|}{$5 \%$ Trimmed Mean } & 72,92 & \\
\hline & & & \multicolumn{2}{|l|}{ Median } & 72,00 & \\
\hline & & & \multicolumn{2}{|l|}{ Variance } & 48,839 & \\
\hline & & & \multicolumn{2}{|l|}{ Std. Deviation } & 6,989 & \\
\hline & & & \multicolumn{2}{|l|}{ Minimum } & 59 & \\
\hline & & & \multicolumn{2}{|l|}{ Maximum } & 81 & \\
\hline & & & \multicolumn{2}{|l|}{ Range } & 22 & \\
\hline & & & \multicolumn{2}{|l|}{ Interquartile Range } & 9 & \\
\hline & & & \multicolumn{2}{|l|}{ Skewness } &,- 875 & ,752 \\
\hline & & & \multicolumn{2}{|l|}{ Kurtosis } & 1,133 & 1,481 \\
\hline & & \multirow[t]{11}{*}{ Positive } & \multicolumn{2}{|l|}{ Mean } & 83,00 & 4,163 \\
\hline & & & \multirow{2}{*}{$\begin{array}{l}95 \% \text { Confidence Interval } \\
\text { for Mean }\end{array}$} & Lower Bound & 65,09 & \\
\hline & & & & Upper Bound & 100,91 & \\
\hline & & & \multicolumn{2}{|l|}{ 5\% Trimmed Mean } & . & \\
\hline & & & \multicolumn{2}{|l|}{ Median } & 81,00 & \\
\hline & & & \multicolumn{2}{|l|}{ Variance } & 52,000 & \\
\hline & & & \multicolumn{2}{|l|}{ Std. Deviation } & 7,211 & \\
\hline & & & \multicolumn{2}{|l|}{ Minimum } & 77 & \\
\hline & & & \multicolumn{2}{|l|}{ Maximum } & 91 & \\
\hline & & & \multicolumn{2}{|l|}{ Range } & 14 & \\
\hline & & & \multicolumn{2}{|l|}{ Interquartile Range } & . & \\
\hline
\end{tabular}




\begin{tabular}{|c|c|c|c|c|c|c|}
\hline & & & \multicolumn{2}{|l|}{ Skewness } & 1,152 & 1,225 \\
\hline & & & \multicolumn{2}{|l|}{ Kurtosis } & & \\
\hline \multirow[t]{26}{*}{ Positive } & \multirow[t]{26}{*}{ Age (yrs) } & \multirow[t]{13}{*}{ Negative } & \multicolumn{2}{|l|}{ Mean } & 63,11 & 4,458 \\
\hline & & & \multirow{2}{*}{$\begin{array}{l}95 \% \text { Confidence Interval } \\
\text { for Mean }\end{array}$} & Lower Bound & 52,83 & \\
\hline & & & & Upper Bound & 73,39 & \\
\hline & & & \multicolumn{2}{|l|}{$5 \%$ Trimmed Mean } & 63,46 & \\
\hline & & & \multicolumn{2}{|l|}{ Median } & 63,00 & \\
\hline & & & \multicolumn{2}{|l|}{ Variance } & 178,861 & \\
\hline & & & \multicolumn{2}{|l|}{ Std. Deviation } & 13,374 & \\
\hline & & & \multicolumn{2}{|l|}{ Minimum } & 39 & \\
\hline & & & \multicolumn{2}{|l|}{ Maximum } & 81 & \\
\hline & & & \multicolumn{2}{|l|}{ Range } & 42 & \\
\hline & & & \multicolumn{2}{|l|}{ Interquartile Range } & 20 & \\
\hline & & & \multicolumn{2}{|l|}{ Skewness } &,- 423 & ,717 \\
\hline & & & \multicolumn{2}{|l|}{ Kurtosis } &,- 077 & 1,400 \\
\hline & & \multirow[t]{13}{*}{ Positive } & \multicolumn{2}{|l|}{ Mean } & 67,73 & 5,514 \\
\hline & & & \multirow{2}{*}{$\begin{array}{l}95 \% \text { Confidence Interval } \\
\text { for Mean }\end{array}$} & Lower Bound & 55,44 & \\
\hline & & & & Upper Bound & 80,01 & \\
\hline & & & \multicolumn{2}{|l|}{ 5\% Trimmed Mean } & 68,25 & \\
\hline & & & \multicolumn{2}{|l|}{ Median } & 70,00 & \\
\hline & & & \multicolumn{2}{|l|}{ Variance } & 334,418 & \\
\hline & & & \multicolumn{2}{|l|}{ Std. Deviation } & 18,287 & \\
\hline & & & \multicolumn{2}{|l|}{ Minimum } & 39 & \\
\hline & & & \multicolumn{2}{|l|}{ Maximum } & 87 & \\
\hline & & & \multicolumn{2}{|l|}{ Range } & 48 & \\
\hline & & & \multicolumn{2}{|l|}{ Interquartile Range } & 39 & \\
\hline & & & \multicolumn{2}{|l|}{ Skewness } &,- 559 & ,661 \\
\hline & & & \multicolumn{2}{|l|}{ Kurtosis } & $-1,359$ & 1,279 \\
\hline
\end{tabular}




\section{Annex 12}

Correlation between Progesterone Receptor Expression and Tumor Size according to Cyclooxygenase-2 Expression

\begin{tabular}{|l|l|l|r|r|r|}
\hline \multicolumn{7}{|c|}{ Ranks } \\
\hline COX-2 status & PR status & $\mathrm{N}$ & Mean Rank & Sum of Ranks \\
\hline \multirow{6}{*}{} & Tumor size $(\mathrm{cm})$ & Negative & 8 & 6,50 & 52,00 \\
\cline { 3 - 7 } & Positive & 3 & 4,67 & 14,00 \\
\cline { 3 - 7 } & Total & 11 & & \\
\cline { 3 - 7 } & Tumor size $(\mathrm{cm})$ & Negative & 9 & 13,44 & 121,00 \\
\cline { 3 - 7 } & Positive & 11 & 8,09 & 89,00 \\
\cline { 3 - 6 } & Total & 20 & & \\
\hline
\end{tabular}

\begin{tabular}{|l|l|r|}
\hline \multicolumn{2}{|c|}{ Test Statistics $^{\text {b }}$} \\
\hline COX-2 status & \multicolumn{1}{|c|}{ Tumor size (cm) } \\
\hline \multirow{5}{*}{ Negative } & Mann-Whitney U & 8,000 \\
\cline { 2 - 3 } & Wilcoxon W & 14,000 \\
\cline { 2 - 3 } & Z &,- 816 \\
\cline { 2 - 3 } & Asymp. Sig. (2-tailed) &, 414 \\
\cline { 2 - 3 } & $\begin{array}{l}\text { Exact Sig. [2*(1-tailed } \\
\text { Positive }\end{array}$ &, $497^{\mathrm{a}}$ \\
& Sig.)] & 23,000 \\
\cline { 2 - 3 } & Mann-Whitney U & 89,000 \\
\cline { 2 - 3 } & Wilcoxon W & $-2,022$ \\
\cline { 2 - 3 } & Z &, 043 \\
\cline { 2 - 3 } & Asymp. Sig. (2-tailed) &, $046^{\mathrm{a}}$ \\
\cline { 2 - 3 } & $\begin{array}{l}\text { Exact Sig. [2*(1-tailed } \\
\text { Sig.)] }\end{array}$ & \\
\hline \multirow{5}{*}{ a. Not corrected for ties. } & \\
\hline b. Grouping Variable: 4. Rp \% & \\
\hline
\end{tabular}




\begin{tabular}{|c|c|c|c|c|c|c|c|c|}
\hline \multicolumn{9}{|c|}{ Case Processing Summary } \\
\hline & & \multirow[b]{3}{*}{ RP status } & \multicolumn{6}{|c|}{ Cases } \\
\hline & & & \multicolumn{2}{|c|}{ Valid } & \multicolumn{2}{|c|}{ Missing } & \multicolumn{2}{|c|}{ Total } \\
\hline \multicolumn{2}{|c|}{ COX-2 status } & & $\mathrm{N}$ & Percent & $\mathrm{N}$ & Percent & $\mathrm{N}$ & Percent \\
\hline \multirow[t]{4}{*}{ Negative } & \multirow[t]{2}{*}{ Age (yrs) } & Negative & 8 & $100,0 \%$ & 0 &, $0 \%$ & 8 & $100,0 \%$ \\
\hline & & Positive & 3 & $100,0 \%$ & 0 &, $0 \%$ & 3 & $100,0 \%$ \\
\hline & \multirow[t]{2}{*}{ Tumor size $(\mathrm{cm})$} & Negative & 8 & $100,0 \%$ & 0 &, $0 \%$ & 8 & $100,0 \%$ \\
\hline & & Positive & 3 & $100,0 \%$ & 0 &, $0 \%$ & 3 & $100,0 \%$ \\
\hline \multirow[t]{4}{*}{ Positive } & \multirow[t]{2}{*}{ Age (yrs) } & Negative & 9 & $100,0 \%$ & 0 &, $0 \%$ & 9 & $100,0 \%$ \\
\hline & & Positive & 11 & $100,0 \%$ & 0 &, $0 \%$ & 11 & $100,0 \%$ \\
\hline & \multirow[t]{2}{*}{ Tumor size $(\mathrm{cm})$} & Negative & 9 & $100,0 \%$ & 0 &, $0 \%$ & 9 & $100,0 \%$ \\
\hline & & Positive & 11 & $100,0 \%$ & 0 & ,0\% & 11 & $100,0 \%$ \\
\hline
\end{tabular}

\begin{tabular}{|c|c|c|c|c|c|c|}
\hline \multicolumn{7}{|c|}{ Descriptives } \\
\hline \multicolumn{2}{|c|}{ COX-2 status } & \multicolumn{3}{|l|}{ PR status } & \multirow{2}{*}{$\begin{array}{r}\text { Statistic } \\
4,60 \\
\end{array}$} & \multirow{2}{*}{\begin{tabular}{|r|} 
Std. Error \\
1,040 \\
\end{tabular}} \\
\hline \multirow[t]{20}{*}{ Negative } & \multirow[t]{20}{*}{ Tumor size $(\mathrm{cm})$} & \multirow[t]{13}{*}{ Negative } & \multicolumn{2}{|l|}{ Mean } & & \\
\hline & & & \multirow{2}{*}{$\begin{array}{l}95 \% \text { Confidence Interval } \\
\text { for Mean }\end{array}$} & Lower Bound & 2,14 & \\
\hline & & & & Upper Bound & 7,06 & \\
\hline & & & \multicolumn{2}{|l|}{ 5\% Trimmed Mean } & 4,53 & \\
\hline & & & \multicolumn{2}{|l|}{ Median } & 4,50 & \\
\hline & & & \multicolumn{2}{|l|}{ Variance } & 8,649 & \\
\hline & & & \multicolumn{2}{|l|}{ Std. Deviation } & 2,941 & \\
\hline & & & \multicolumn{2}{|l|}{ Minimum } & 1 & \\
\hline & & & \multicolumn{2}{|l|}{ Maximum } & 9 & \\
\hline & & & \multicolumn{2}{|l|}{ Range } & 8 & \\
\hline & & & \multicolumn{2}{|l|}{ Interquartile Range } & 6 & \\
\hline & & & \multicolumn{2}{|l|}{ Skewness } & ,252 & ,752 \\
\hline & & & \multicolumn{2}{|l|}{ Kurtosis } & $-1,641$ & 1,481 \\
\hline & & \multirow[t]{7}{*}{ Positive } & \multicolumn{2}{|l|}{ Mean } & 2,20 & ,208 \\
\hline & & & \multirow{2}{*}{$\begin{array}{l}95 \% \text { Confidence Interval } \\
\text { for Mean }\end{array}$} & Lower Bound & 1,30 & \\
\hline & & & & Upper Bound & 3,10 & \\
\hline & & & \multicolumn{2}{|l|}{$5 \%$ Trimmed Mean } & . & \\
\hline & & & \multicolumn{2}{|l|}{ Median } & 2,30 & \\
\hline & & & \multicolumn{2}{|l|}{ Variance } & ,130 & \\
\hline & & & \multicolumn{2}{|l|}{ Std. Deviation } & ,361 & \\
\hline
\end{tabular}




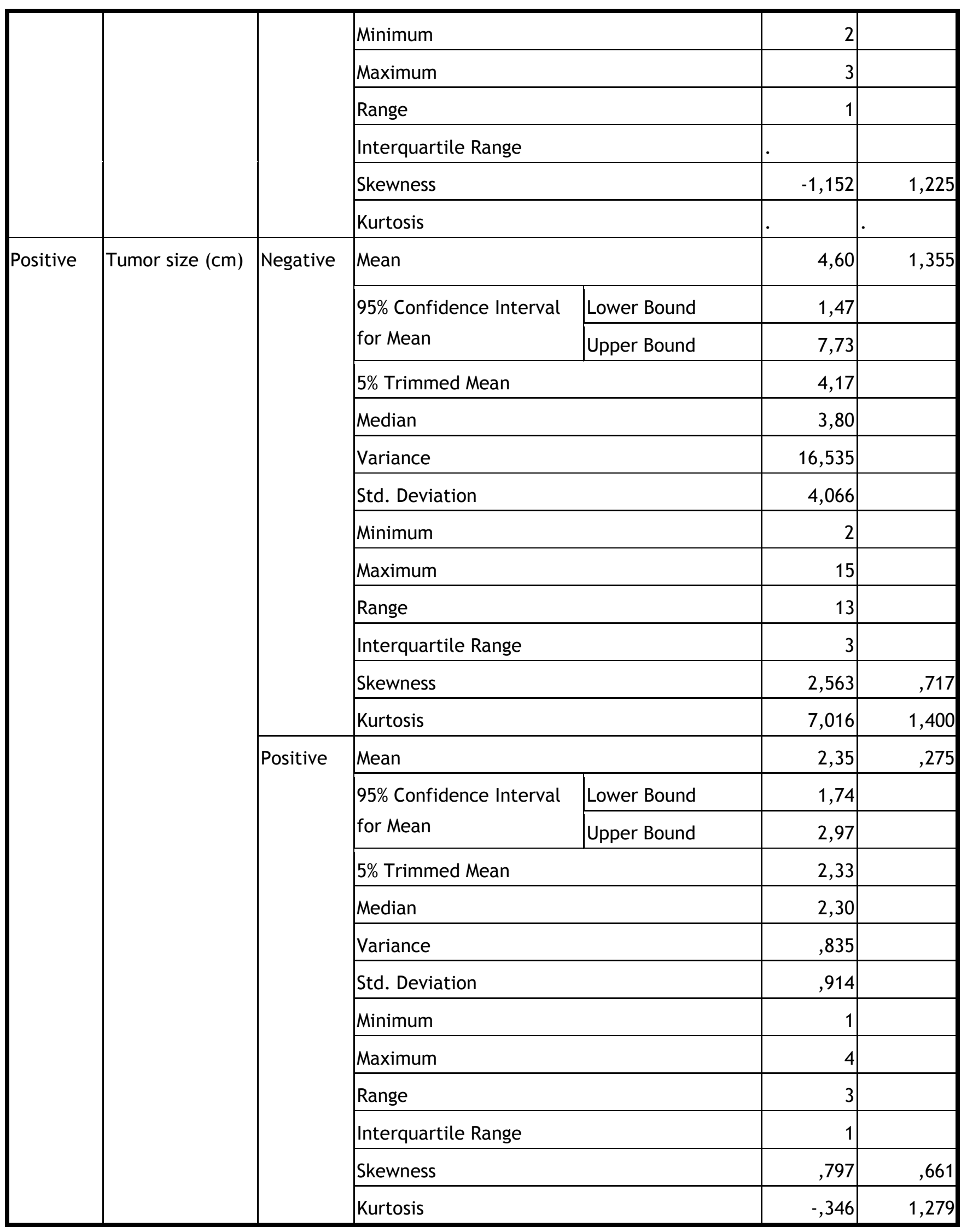




\section{Annex 13}

Correlation between Progesterone Receptor Expression and Differentiation Grade according to Cyclooxygenase-2 Expression

\begin{tabular}{|c|c|c|c|c|c|c|}
\hline \multicolumn{7}{|c|}{ Case Processing Summary } \\
\hline & \multicolumn{6}{|c|}{ Cases } \\
\hline & \multicolumn{2}{|c|}{ Valid } & \multicolumn{2}{|c|}{ Missing } & \multicolumn{2}{|c|}{ Total } \\
\hline & $\mathrm{N}$ & Percent & $\mathrm{N}$ & Percent & $N$ & Percent \\
\hline $\begin{array}{l}\text { PR status * } \\
\text { Differentiation grade * } \\
\text { COX-2 status }\end{array}$ & 31 & $100,0 \%$ & 0 & ,0\% & 31 & $100,0 \%$ \\
\hline
\end{tabular}

\begin{tabular}{|c|c|c|c|c|c|c|}
\hline \multicolumn{7}{|c|}{ Crosstab } \\
\hline \multirow{2}{*}{\multicolumn{4}{|c|}{ COX-2 status }} & \multicolumn{2}{|c|}{ Differentiation grade } & \multirow[b]{2}{*}{ Total } \\
\hline & & & & 1 & 2 or 3 & \\
\hline \multirow[t]{12}{*}{ Negative } & \multirow[t]{8}{*}{ PR status } & \multirow[t]{4}{*}{ Negative } & Count & 0 & 8 & 8 \\
\hline & & & $\%$ within PR status &, $0 \%$ & $100,0 \%$ & $100,0 \%$ \\
\hline & & & $\begin{array}{l}\text { \% within Differentiation } \\
\text { grade }\end{array}$ &, $0 \%$ & $80,0 \%$ & $72,7 \%$ \\
\hline & & & $\%$ of Total &, $0 \%$ & $72,7 \%$ & $72,7 \%$ \\
\hline & & \multirow[t]{4}{*}{ Positive } & Count & 1 & 2 & 3 \\
\hline & & & $\%$ within PR status & $33,3 \%$ & $66,7 \%$ & $100,0 \%$ \\
\hline & & & $\begin{array}{l}\text { \% within Differentiation } \\
\text { grade }\end{array}$ & $100,0 \%$ & $20,0 \%$ & $27,3 \%$ \\
\hline & & & $\%$ of Total & $9,1 \%$ & $18,2 \%$ & $27,3 \%$ \\
\hline & \multirow{4}{*}{\multicolumn{2}{|c|}{ Total }} & Count & 1 & 10 & 11 \\
\hline & & & $\%$ within PR status & $9,1 \%$ & $90,9 \%$ & $100,0 \%$ \\
\hline & & & $\begin{array}{l}\text { \% within Differentiation } \\
\text { grade }\end{array}$ & $100,0 \%$ & $100,0 \%$ & $100,0 \%$ \\
\hline & & & $\%$ of Total & $9,1 \%$ & $90,9 \%$ & $100,0 \%$ \\
\hline \multirow[t]{4}{*}{ Positive } & \multirow[t]{4}{*}{ PR status } & \multirow[t]{4}{*}{ Negative } & Count & 2 & 7 & 9 \\
\hline & & & $\%$ within PR status & $22,2 \%$ & $77,8 \%$ & $100,0 \%$ \\
\hline & & & $\begin{array}{l}\% \text { within Differentiation } \\
\text { grade }\end{array}$ & $33,3 \%$ & $50,0 \%$ & $45,0 \%$ \\
\hline & & & $\%$ of Total & $10,0 \%$ & $35,0 \%$ & $45,0 \%$ \\
\hline
\end{tabular}




\begin{tabular}{|c|c|c|c|c|c|}
\hline & \multirow[t]{4}{*}{ Positive } & Count & 4 & 7 & 11 \\
\hline & & $\%$ within PR status & $36,4 \%$ & $63,6 \%$ & $100,0 \%$ \\
\hline & & $\begin{array}{l}\% \text { within Differentiation } \\
\text { grade }\end{array}$ & $66,7 \%$ & $50,0 \%$ & $55,0 \%$ \\
\hline & & $\%$ of Total & $20,0 \%$ & $35,0 \%$ & $55,0 \%$ \\
\hline \multirow[t]{4}{*}{ Total } & & Count & 6 & 14 & 20 \\
\hline & & $\%$ within PR status & $30,0 \%$ & $70,0 \%$ & $100,0 \%$ \\
\hline & & $\begin{array}{l}\% \text { within Differentiation } \\
\text { grade }\end{array}$ & $100,0 \%$ & $100,0 \%$ & $100,0 \%$ \\
\hline & & $\%$ of Total & $30,0 \%$ & $70,0 \%$ & $100,0 \%$ \\
\hline
\end{tabular}

\begin{tabular}{|c|c|c|c|c|c|c|}
\hline \multicolumn{7}{|c|}{ Chi-Square Tests } \\
\hline \multicolumn{2}{|c|}{ COX-2 status } & \multirow{2}{*}{$\frac{\text { Value }}{2,933^{\mathrm{a}}}$} & \multirow{2}{*}{\begin{tabular}{l|l} 
df & \\
& \\
\end{tabular}} & \multirow{2}{*}{\begin{tabular}{|r|}
$\begin{array}{c}\text { Asymp. Sig. (2- } \\
\text { sided) }\end{array}$ \\
, 087
\end{tabular}} & \multirow[t]{2}{*}{$\begin{array}{c}\text { Exact Sig. (2- } \\
\text { sided) }\end{array}$} & \multirow[t]{2}{*}{$\begin{array}{c}\text { Exact Sig. (1- } \\
\text { sided) }\end{array}$} \\
\hline Negative & Pearson Chi-Square & & & & & \\
\hline & Continuity Correction ${ }^{\mathrm{b}}$ & ,286 & 1 & ,592 & & \\
\hline & Likelihood Ratio & 2,883 & 1 & 090 & & \\
\hline & Fisher's Exact Test & & & & ,273 & ,273 \\
\hline & $\begin{array}{l}\text { Linear-by-Linear } \\
\text { Association }\end{array}$ & 2,667 & 1 & ,102 & & \\
\hline & $\mathrm{N}$ of Valid Cases & 11 & & & & \\
\hline \multirow[t]{6}{*}{ Positive } & Pearson Chi-Square &, $471^{c}$ & 1 & ,492 & & \\
\hline & Continuity Correction ${ }^{\mathrm{b}}$ & ,038 & 1 & ,844 & & \\
\hline & Likelihood Ratio & ,479 & 1 & ,489 & & \\
\hline & Fisher's Exact Test & & & & ,642 & ,426 \\
\hline & $\begin{array}{l}\text { Linear-by-Linear } \\
\text { Association }\end{array}$ & ,448 & 1 &, 503 & & \\
\hline & $\mathrm{N}$ of Valid Cases & 20 & & & & \\
\hline \multicolumn{7}{|c|}{ a. 3 cells $(75,0 \%)$ have expected count less than 5 . The minimum expected count is, 27 . } \\
\hline \multicolumn{7}{|c|}{ b. Computed only for a $2 \times 2$ table } \\
\hline c. 2 cells & $50,0 \%)$ have expected $c$ & s than 5 & he minin & mum expected & ount is 2,70 . & \\
\hline
\end{tabular}




\begin{tabular}{|c|c|c|c|c|}
\hline \multicolumn{5}{|c|}{ Risk Estimate } \\
\hline \multirow{2}{*}{\multicolumn{2}{|c|}{ COX-2 status }} & \multirow{3}{*}{$\frac{\text { Value }}{1,500}$} & \multicolumn{2}{|c|}{ 95\% Confidence Interval } \\
\hline & & & Lower & Upper \\
\hline \multirow[t]{2}{*}{ Negative } & $\begin{array}{l}\text { For cohort Differentiation } \\
\text { grade }=2 \text { or } 3\end{array}$ & & ,674 & 3,339 \\
\hline & N of Valid Cases & 11 & & \\
\hline \multirow[t]{4}{*}{ Positive } & $\begin{array}{l}\text { For cohort Differentiation } \\
\text { grade }=2 \text { or } 3\end{array}$ & 1,222 & ,693 & 2,155 \\
\hline & $\mathrm{N}$ of Valid Cases & 20 & & \\
\hline & $\begin{array}{l}\text { Odds Ratio for } 4 . \text { Rp } \% \\
\text { (Negativo / Positivo) }\end{array}$ &, 500 & ,068 & 3,675 \\
\hline & $\begin{array}{l}\text { For cohort Differentiation } \\
\text { grade }=1\end{array}$ & ,611 &, 143 & 2,608 \\
\hline
\end{tabular}




\section{Annex 14}

Correlation between Progesterone Receptor Expression and Axillary Node Metastasis according to Cyclooxygenase-2 Expression

\begin{tabular}{|c|c|c|c|c|c|c|}
\hline \multicolumn{7}{|c|}{ Case Processing Summary } \\
\hline & \multicolumn{6}{|c|}{ Cases } \\
\hline & \multicolumn{2}{|c|}{ Valid } & \multicolumn{2}{|c|}{ Missing } & \multicolumn{2}{|c|}{ Total } \\
\hline & $\mathrm{N}$ & Percent & $\mathrm{N}$ & Percent & $\mathrm{N}$ & Percent \\
\hline $\begin{array}{l}\text { PR status * Axillary node } \\
\text { metastasis* COX-2 status }\end{array}$ & 31 & $100,0 \%$ & 0 &, $0 \%$ & 31 & $100,0 \%$ \\
\hline
\end{tabular}

\begin{tabular}{|c|c|c|c|c|c|c|}
\hline \multicolumn{7}{|c|}{ Crosstab } \\
\hline \multirow{2}{*}{\multicolumn{4}{|c|}{ COX-2 status }} & \multicolumn{2}{|c|}{$\begin{array}{c}\text { Axillary node } \\
\text { metastasis }\end{array}$} & \multirow[b]{2}{*}{ Total } \\
\hline & & & & No & Yes & \\
\hline \multirow[t]{12}{*}{ Negative } & \multirow[t]{8}{*}{ PR status } & \multirow[t]{4}{*}{ Negative } & Count & 4 & 4 & 8 \\
\hline & & & $\%$ within PR status & $50,0 \%$ & $50,0 \%$ & $100,0 \%$ \\
\hline & & & $\begin{array}{l}\% \text { within axillary node } \\
\text { metastasis }\end{array}$ & $66,7 \%$ & $80,0 \%$ & $72,7 \%$ \\
\hline & & & $\%$ of Total & $36,4 \%$ & $36,4 \%$ & $72,7 \%$ \\
\hline & & \multirow[t]{4}{*}{ Positive } & Count & 2 & 1 & 3 \\
\hline & & & $\%$ within PR status & $66,7 \%$ & $33,3 \%$ & $100,0 \%$ \\
\hline & & & $\begin{array}{l}\% \text { within axillary node } \\
\text { metastasis }\end{array}$ & $33,3 \%$ & $20,0 \%$ & $27,3 \%$ \\
\hline & & & $\%$ of Total & $18,2 \%$ & $9,1 \%$ & $27,3 \%$ \\
\hline & \multirow{4}{*}{\multicolumn{2}{|c|}{ Total }} & Count & 6 & 5 & 11 \\
\hline & & & $\%$ within PR status & $54,5 \%$ & $45,5 \%$ & $100,0 \%$ \\
\hline & & & $\begin{array}{l}\% \text { within axillary node } \\
\text { metastasis }\end{array}$ & $100,0 \%$ & $100,0 \%$ & $100,0 \%$ \\
\hline & & & $\%$ of Total & $54,5 \%$ & $45,5 \%$ & $100,0 \%$ \\
\hline \multirow[t]{4}{*}{ Positive } & \multirow[t]{4}{*}{ PR status } & \multirow[t]{4}{*}{ Negative } & Count & 5 & 4 & 9 \\
\hline & & & $\%$ within PR status & $55,6 \%$ & $44,4 \%$ & $100,0 \%$ \\
\hline & & & $\begin{array}{l}\% \text { within axillary node } \\
\text { metastasis }\end{array}$ & $31,3 \%$ & $100,0 \%$ & $45,0 \%$ \\
\hline & & & $\%$ of Total & $25,0 \%$ & $20,0 \%$ & $45,0 \%$ \\
\hline
\end{tabular}




\begin{tabular}{|c|c|c|c|c|c|}
\hline & \multirow[t]{4}{*}{ Positive } & Count & 11 & 0 & 11 \\
\hline & & $\%$ within PR status & $100,0 \%$ & ,0\% & $100,0 \%$ \\
\hline & & $\begin{array}{l}\% \text { within axillary node } \\
\text { metastasis }\end{array}$ & $68,8 \%$ &, $0 \%$ & $55,0 \%$ \\
\hline & & $\%$ of Total & $55,0 \%$ & ,0\% & $55,0 \%$ \\
\hline \multirow[t]{4}{*}{ Total } & & Count & 16 & 4 & 20 \\
\hline & & $\%$ within PR status & $80,0 \%$ & $20,0 \%$ & $100,0 \%$ \\
\hline & & $\begin{array}{l}\% \text { within axillary node } \\
\text { metastasis }\end{array}$ & $100,0 \%$ & $100,0 \%$ & $100,0 \%$ \\
\hline & & $\%$ of Total & $80,0 \%$ & $20,0 \%$ & $100,0 \%$ \\
\hline
\end{tabular}

\begin{tabular}{|c|c|c|c|c|c|c|}
\hline \multicolumn{7}{|c|}{ Chi-Square Tests } \\
\hline \multicolumn{2}{|c|}{ COX-2 status } & \multirow{2}{*}{$\begin{array}{l}\text { Value } \\
, 244^{\mathrm{a}}\end{array}$} & \multirow{2}{*}{\begin{tabular}{l|l} 
df & \\
& 1
\end{tabular}} & \multirow{2}{*}{\begin{tabular}{|r|}
$\begin{array}{c}\text { Asymp. Sig. (2- } \\
\text { sided) }\end{array}$ \\
, 621 \\
\end{tabular}} & \multirow[t]{2}{*}{$\begin{array}{c}\text { Exact Sig. (2- } \\
\text { sided) }\end{array}$} & \multirow[t]{2}{*}{$\begin{array}{c}\text { Exact Sig. (1- } \\
\text { sided) }\end{array}$} \\
\hline Negative & Pearson Chi-Square & & & & & \\
\hline & Continuity Correction ${ }^{\mathrm{b}}$ & ,000 & 1 & 1,000 & & \\
\hline & Likelihood Ratio & ,249 & 1 & 618 & & \\
\hline & Fisher's Exact Test & & & & 1,000 &, 576 \\
\hline & $\begin{array}{l}\text { Linear-by-Linear } \\
\text { Association }\end{array}$ & ,222 & 1 & ,637 & & \\
\hline & $\mathrm{N}$ of Valid Cases & 11 & & & & \\
\hline \multirow[t]{6}{*}{ Positive } & Pearson Chi-Square & $6,111^{c}$ & 1 & ,013 & & \\
\hline & Continuity Correction ${ }^{\mathrm{b}}$ & 3,649 & 1 & ,056 & & \\
\hline & Likelihood Ratio & 7,651 & 1 & ,006 & & \\
\hline & Fisher's Exact Test & & & & 026 & 026 \\
\hline & $\begin{array}{l}\text { Linear-by-Linear } \\
\text { Association }\end{array}$ & 5,806 & 1 & ,016 & & \\
\hline & $\mathrm{N}$ of Valid Cases & 20 & & & & \\
\hline \multicolumn{7}{|c|}{ a. 4 cells $(100,0 \%)$ have expected count less than 5 . The minimum expected count is 1,36 . } \\
\hline \multicolumn{7}{|c|}{ b. Computed only for a $2 \times 2$ table } \\
\hline c. 2 cells & $(50,0 \%)$ have expected $c$ & $s$ than 5 & e minin & mum expected & ount is 1,80 . & \\
\hline
\end{tabular}




\begin{tabular}{|c|c|c|c|c|}
\hline \multicolumn{5}{|c|}{ Risk Estimate } \\
\hline \multirow{2}{*}{\multicolumn{2}{|c|}{ COX-2 status }} & \multirow{3}{*}{$\begin{array}{r}\text { Value } \\
, 500\end{array}$} & \multicolumn{2}{|c|}{ 95\% Confidence Interval } \\
\hline & & & Lower & Upper \\
\hline \multirow[t]{4}{*}{ Negative } & $\begin{array}{l}\text { Odds Ratio for PR status } \\
\text { (Negative / Positive) }\end{array}$ & & ,031 & 7,994 \\
\hline & $\begin{array}{l}\text { For cohort Ganglion } \\
\text { metastasis = No }\end{array}$ & ,750 & ,260 & 2,162 \\
\hline & $\begin{array}{l}\text { For cohort Ganglion } \\
\text { metastasis = Yes }\end{array}$ & 1,500 & ,262 & 8,579 \\
\hline & N of Valid Cases & 11 & & \\
\hline \multirow[t]{2}{*}{ Positive } & $\begin{array}{l}\text { For cohort Ganglion } \\
\text { metastasis = No }\end{array}$ &, 556 & ,310 & ,997 \\
\hline & $\mathrm{N}$ of Valid Cases & 20 & & \\
\hline
\end{tabular}




\title{
Annex 15
}

\author{
Journal Article Submitted for Publication
}

\section{Cyclooxygenase-2 immunoexpression in breast cancer: Progesterone Receptors Influence}

\author{
Micaela Almeida, Javier Muñoz, José Moutinho
}

\begin{abstract}
In breast cancer Cyclooxygenase-2 overexperssion is related with poor outcomes, but the clinical relevance of Cyclooxygenase-2 is still unclear. Progesterone Receptor is a regulator of Cyclooxygenase-2 expression. We postulate that Progesterone Receptor was associated to Cyclooxygenase-2 expression and clinicophatologic factors in breast cancer. Cyclooxygenase-2 and Progesterone Receptor expression was analyzed, by immunohistochemistry, in 31 cases of invasive ductal carcinoma. The expression of Cyclooxygenase-2 and progesterone receptor was observed in $64.5 \%$ and $45.2 \%$ of the tumors, respectively. We found tumors 11 with both Cyclooxygenase-2 and progesterone receptor overexpression and they are related with tumor lower size and lower axillary node metastasis. These results suggest that progesterone receptor has a protective role in breast cancer by inhibiting chronic inflammatory pathway.
\end{abstract}

\section{Introduction}

Cyclooxigenase-2 (COX-2) is the induced cyclooxygenase (COX) isoform, is expressed in most tissues and commonly expressed in more than $50 \%$ of invasive breast cancers [1,2]. COX-2 is involved in chronic inflammation and is responsible for arachidonic acid (AA) conversion into prostaglandins, which are associated with increased aromatase that in turn results in high local estrogen receptor (ER) levels [3-7].

It has long been thought that ER induced progesterone receptor (PR) and that serves as an indicator of ER functional capacity; new studies indicate that PR is an independent prognostic risk factor predictor and may have protective actions by antagonizing inflammatory response pathway (fig. 1) [3].

$\mathrm{PR}$ impairs transactivation of COX-2 through nuclear factor kappa $\mathrm{B}(\mathrm{NF}-\mathrm{kB})$ via inhibitory factor $\mathrm{kBa}$ $(\mathrm{IKB \alpha})[8,9]$. NF-KB inhibition by PR, results in estrogen lower levels. In that way and PR modelates breast tumor development and progression $[3,10]$.

In clinical ground PR has protective role in breast cancer, this is the reason why $\mathrm{ER}^{+} / \mathrm{PR}^{-}$tumor subtype are more aggressive, have high proliferation rates and higher recurrence than $\mathrm{ER}^{+} / \mathrm{PR}^{+}[8]$.

The aim of this study was to determine if COX-2 and PR imunoexpression, had correlation with clinicopathologic factors (age, tumor size, histologic grade and axillary node metastasis), which are known to be prognostic factors.

\section{Methods}

\section{Patient selection}

There were selected 31 patients who were diagnosed, between 2007 and 2009, with breast cancer in Child and Women department of Cova da Beira Medical Center in Portugal. All cases were invasive ductal carcinoma. There were excluded tumors with less than $10 \mathrm{~mm}$, to preserve archive material. There were excluded all pregnant women and patients submitted to primary chemotherapy or hormonotherapy. In all cases there was no distant metastasis, all patients were submitted to radical breast tumor excision and sentinel mapping linfadenectomy. Although the short period of time there was not recorded any case of recurrence.

\section{Immunostaining}

Paraffin-embedded samples of $3 \mu \mathrm{m}$ were cut and processed for immunostaining. For each case of study were selected three slides, one for hematoxylin-eosin staining and the remaining two for COX-2 and PR immunostaining. There was performed a dewaxing with xylene, followed by rehydration in decreasing ethanol grades and water. For antigen retrieval, slides were put into pressure cooker and citrate buffer $0.01 \mathrm{M}$ for 6 minutes at $\mathrm{pH} 6$ and washed with water and buffer solution (K5006, ChemMat ${ }^{\mathrm{TM}}$, Dako). Slides were incubated with the primary antibody, for COX-2 staining was used clone SP21, rabbit 
monoclonal antibody (MC-16-240r, CellMarque ${ }^{\mathrm{TM}}$ ) at 1:10 dilution; for PR staining were used clone 16 and clone SAN27 (NCL-L-PGR-AB, Novocastra ${ }^{\text {TM}}$ ) at 1:100 dilution, in both cases the diluent used was S2022 (Dako Real). Incubation with the primary anti-body was made for 25 minutes at room temperature, then washed with buffer solution (K5006, ChemMat TM, Dako). Incubation with biotinylated secondary antibody was made for 25 minutes, using the bottle A from K5001 kit (Dako Real ${ }^{\mathrm{TM}}$ ), followed by washing with buffer solution (K5006, ChemMat TM, Dako). To block endogenous peroxidase there was used a blokingPeroxidase solution (S2023, Dako Real ${ }^{\mathrm{TM}}$ ) for 7 minutes and 30 seconds, followed by washing with buffer solution (K5006, ChemMat TM, Dako). It was added streptavidin conjugated horseradish peroxidase (HRP) (bottle B, K5001, Dako Real), for 25 minutes followed by washing with buffer solution (K5006, ChemMat TM, Dako), chromogen was added (Dako Real DAB + chromogen, bottle C + HRP substrate buffer bottle D, K5001, Dako Real) at a 20:1000 dilution for 15 min with washes at every 5 minutes, this was followed by washing with a buffer solution (K5006, ChemMat TM, Dako). The counterstaining was done with Mayer's hematoxylin for $1 \mathrm{~min}$ and washed with a buffer solution (K5006, ChemMat TM, Dako), dehydrated in increasing ethanol grades $(75 \%, 90 \%$, absolute) and xylene. Slides were preserved in synthetic mounting medium, and were analyzed with an optical microscope (x400), using 50 fields for slide.

For Cox-2 was considered cytoplasmatic immunostaining and to PR was recorded nuclear immunostaining.

The Immunostaining intensity was recorded, by an independent pathologist, as: negative if no staining; high if staining is similar to positive control and Moderate if intensity of the staining is less than positive control.

Positivity of Immunostaining was recorded as percentage of the cells that stained, independently of intensity of the staining. It was counted all cells in an optical high power field considered representative of all slide, in a minimum of 500 cells. For statically analysis we considered staining in less than $25 \%$ of the cell as a negative result; 25 to $50 \%$ of the cells as light expression; $50-75 \%$ as moderate expression and 75 to $100 \%$ as a high expression.

For comparative statically analysis we considered as positive cases immunostaining in at least $50 \%$ of the cells and moderate and high intensity of the staining. All other was considered as negative cases.

\section{Statistical analysis}

Statistical analysis was performed using SPSS, version 17. Mann-Whitney and Chi-Squared tests were used for the analysis, considering a statistical significance when $\mathrm{P}$-value was $<0.05$.

\section{Results}

The analyzed clinical cases were between the year 2007 and 2009 and the age of patients varied from 39 to 91 years old. Most of the tumors expressed COX-2 (64.52\%) and $45.16 \%$ of the tumors expressed PR. It was also taking into account the differentiation grade and axillary node metastasis, and we verified that twenty four of tumors had a high (G2 or G3) differentiation grade and only $29.03 \%$ of women had axillary node metastasis (table 1 ).

COX-2 expression was considered positive by semiquantitative scoring in 20 of 31 cases studied $(64,52 \%)$, all 20 cases had a moderate or high expression (equal or greater than $50 \%$ ). Immunostaining intensity was considered moderate in 18 cases and high in 2 cases (fig. 2). PR expression was detected in 14 of 31 cases in study $(45,16 \%)$, all 14 cases had moderate or high expression (equal or greater thar $50 \%$ ) (fig. 3).

\section{Correlation of COX-2 and PR expression with clinicopathological parameter}

In order to evaluate any association between PR and COX-2 immunoexpression it was constituted 4 groups: positive COX-2 expression with positive PR expression (COX-2 $/ \mathrm{PR}^{+}$), positive COX-2 expression with negative PR expression $\left(\mathrm{COX}-2^{+} / \mathrm{PR}^{-}\right)$, negative COX-2 expression with positive PR expression $\left(\mathrm{COX}^{-} / \mathrm{PR}^{+}\right)$and negative COX-2 expression with negative PR expression (COX-2/PR $)$.

COX-2+/PR+ group is constituted for 11 of 31 cases $(35.48 \%), \mathrm{COX}^{+} 2^{+} / \mathrm{PR}^{-}$group is constituted for 9 of 31 cases $(29.03 \%)$, COX-2/PR ${ }^{+}$group is constituted for 3 of 31 cases $(9.68 \%)$ and COX-2/PR group is constituted for 8 of 31 cases $(25.81 \%$ ) (table 2$)$. These groups were correlated with clinicopathological factors and we found that COX-2/PR group is more heterogeneous, ranging the size from $14 \mathrm{~mm}$ to $90 \mathrm{~mm}$, and the group COX-2/PR ${ }^{+}$the more homogeneous (fig. 4a), however there was not found statistical significance $(\mathrm{p}=0.414)$. Similar results were found for COX $-2^{+} / \mathrm{PR}^{-}$group, with higher standard deviation (4.066) and higher mean (4.60) than $\mathrm{COX}-2^{+} / \mathrm{PR}^{+}$group, which as 0.914 and 2.35 for standard deviation and mean, respectively (fig. $4 b)$. Comparing these two groups we found statistical significance ( $p$ $<0.05)$.

Comparing COX-2 expression and PR expression with axillary node metastasis we found that COX-2/PR- group has a higher number of cases with axillay node metastasis $(n=4)$ and without axillary node metastasis $(n=4)$ than COX-2/PR ${ }^{+}$group (fig. $\left.5 a\right)$, but there was not found statistical significance. Unlike these results, we found statistical significance between COX $-2^{+} / \mathrm{PR}^{-}$and $\mathrm{COX}-2^{+} / \mathrm{PR}^{+}$groups $(\mathrm{p}<0.05)$. In $\mathrm{COX}-2^{+} / \mathrm{PR}^{+}$there are no cases with axillary node metastasis and in $\mathrm{COX}-2^{+} / \mathrm{PR}^{+}$group there are 4 cases (44.4\%) with axillary node metastasis and 5 cases (55.6\%) without axillary node metastasis (fig.5b). 
There was also performed a correlation between COX-2 and PR expression with age and differentiation grade, however there was not found statistical significance in any case (data not shown).

\section{Discussion}

This study evaluates COX-2 and PR immunostaining only in ductal invasive breast cancer in patients not submitted to primary chemotherapy, radiotherapy or hormone therapy. In our knowledge is the first study that evaluates specifically that kind breast cancer. There was studied only invasive ductal tumors because they are more frequent and their behavior was more clarified. The role of chronic inflammation in breast cancer is poorly understood. COX-2 overexpression is a marker of chronic inflammation, PR has been appointed as a modulator of COX-2. Our study suggests that COX-2 and PR expression are related with lower size and lower tumor node metastasis. These results have no concordance with that ones found by Lee et al. who did not establish a correlation between PR expression, COX-2 expression and clinicopathological factors [11]. The discrepancy on their results may be reflecting different methology: they considered $>10 \%$ PR or COX-2 of staining as a positive case and in our study only the cases with at least $50 \%$ of staining were considered as positive. Our methodology seems more reasonable in order to avoid false positive cases. Age and tumor differentiation grade represents important factors for breast cancer, but in our study COX-2 and PR immunostaining had not significant statistical association with clinical and pathological factors, probably due to the low number of cases studied.

Despite PR role in breast cancer is unclear, Hardy et al. verified in cellular breast cancer lines, PR antagonizes COX-2 expression [10]. PR acts as a dependent and independent ligand to inhibit NF-KB (COX-2 transcriptional factor) transactivation $[3,10]$. PR interferes with COX-2 transactivation through NF$\mathrm{KB}$, via $\mathrm{I} \mathrm{KBa}$ induction, which modulates COX-2 expression. COX-2 expression augments aromatase activity with consequent local increase of ER $[3,10]$. PR decreases COX-2 expression, with consequent decrease of activity and ER levels $[3,10]$. Probably this is the reason why PR hormone tumors are more aggressive and have higher proliferation rates when compared with $\mathrm{PR}^{+}$hormone tumors, in a independent way of ER immunostaining [8]. Thus, high levels of PR in breast epithelial cells, plays a protective role in breast cancer, by modulating inflammatory response pathway.

Our results have shown that $\mathrm{COX}-2^{+} / \mathrm{PR}^{+}$was associated with lower tumor size and lower axillary node metastasis, suggesting that PR positive ductal invasive breast cancer may have different behavior in according of COX-2 expression. In fact, COX $-2^{+} / \mathrm{PR}^{+}$immunoexpression seems to represent a marker for better prognosis. We speculate if COX-2 expression will be related with better disease-free survival and overall-survival in patients immunopositive for PR submitted to adjuvant hormonal therapy. Clinical studies may clarify the usefulness of the COX-2 immunostaining in clinical practice.

\section{Bibliography}

1. Haffty, B., et al., Estrogen-dependent prognostic significance of cyclooxygenase-2 expression in early-stage invasive breast cancers treated with breast-conserving surgeryand radiation. International Journal of Radiation Oncology • Biology • Physics, 2008. 71: p. 1006-1013.

2. Singh-Ranger, G., M. Salhab, and K. Mokbel, The role of cyclooxygenase-2 in breast cancer: review. Breast Cancer Research Treatment 2008. 109: p. 189-198.

3. Mendelson, C. and D. Hardy, Role of the progesterone receptor $(P R)$ in the regulation of inflammatory response pathways and aromatase in the breast. The Journal of Steroid Biochemestry \& Molecular Biology, 2006. 102: p. 241-249.

4. Schetter, A., N. Heegaard, and C. Harris, Inflammation and cancer: interweaving microRNA, free radical, cytokine and p53 pathways. Carcinogenesis, 2010. 31: p. 37-49.

5. DeNardo, D.G. and L. Coussens, Inflammation and breast cancer. Balancing immune response: crosstalk between adaptive and innate immune cells during breast cancer progression. Breast Cancer Research, 2007. 9: p. 212.

6. Mantovani, A., et al., Cancer-related inflammation. Nature, 2008. 454: p. 436-444.

7. Subbaramaiah, K., et al., HER-2/neu status is a determinant of mammary aromatase activity in vivo: evidence for a cyclooxygenase-2-dependent mechanism. Cancer Research, 2006. 66: p. 5504-5511.

8. Arpino, G., et al., Estrogen receptor positive, progesterone receptor-negative breast cancer: association with growth factor receptor expression and tamoxifen resistance. Journal of the National Cancer Institute 2005. 97: p. 1254-1261.

9. Cui, X., et al., Biology of progesterone receptor loss in breast cancer and its implications for endocrine therapy. Journal of Clinical Oncology, 2005. 23: p. 7721-7735.

10. Hardy, D., et al., Progesterone receptor inhibits aromatase and inflammatory response pathway in breast cancer cells via ligand-dependet and ligand-independent mechanisms. Molecular Endocrinology, 2008. 22: p. 1812-1824.

11. Lee, J., et al., Correlation between COX-2 expression and hormone receptors in invasive ductal breast cancer. Journal of Korean Surgical Society, 2010. 78: p. 140-148. 


\section{Images}

Table 1: Patient characteristics: Year, Age, COX-2 expression, PR expression, Tumor Size, Differentiation grade and axillary node metastasis.

\begin{tabular}{|c|c|c|}
\hline Characteristics & N. ${ }^{\circ}$ of Patients & (\%) \\
\hline \multicolumn{3}{|l|}{ Year: } \\
\hline 2007 & 13 & $41.94 \%$ \\
\hline 2008 & 15 & $48.39 \%$ \\
\hline 2009 & 6 & $19.35 \%$ \\
\hline \multicolumn{3}{|l|}{ Age: } \\
\hline$<40$ & 2 & $6.45 \%$ \\
\hline$\geq 40<50$ & 2 & $6.45 \%$ \\
\hline$\geq 50<60$ & 3 & $9.68 \%$ \\
\hline$\geq 60<70$ & 6 & $19.35 \%$ \\
\hline$\geq 70<80$ & 9 & $29.03 \%$ \\
\hline$\geq 80<90$ & 8 & $25.81 \%$ \\
\hline$\geq 90$ & 1 & $3.23 \%$ \\
\hline \multicolumn{3}{|l|}{ COX-2 staining: } \\
\hline Negative & 11 & $35.48 \%$ \\
\hline Moderate & 18 & $58.06 \%$ \\
\hline High & 2 & $6.45 \%$ \\
\hline \multicolumn{3}{|l|}{ COX-2 expression: } \\
\hline $0-25 \%$ & 11 & $35.48 \%$ \\
\hline $25 \%-50 \%$ & 14 & $45.16 \%$ \\
\hline $50 \%-75 \%$ & 5 & $16.13 \%$ \\
\hline $75 \%-100 \%$ & 1 & $3.23 \%$ \\
\hline \multicolumn{3}{|l|}{ PR staining: } \\
\hline Negative & 17 & $54.84 \%$ \\
\hline Moderate & 10 & $32.26 \%$ \\
\hline High & 4 & $12.90 \%$ \\
\hline \multicolumn{3}{|l|}{ PR expression: } \\
\hline $0-25 \%$ & 17 & $54.84 \%$ \\
\hline $25 \%-50 \%$ & 5 & $16.13 \%$ \\
\hline $50 \%-75 \%$ & 6 & $19.35 \%$ \\
\hline $75 \%-100 \%$ & 3 & $9.68 \%$ \\
\hline \multicolumn{3}{|l|}{ Tumor size $(\mathrm{mm})$ : } \\
\hline$<20$ & 10 & $32.26 \%$ \\
\hline$\geq 20<50$ & 15 & $48.39 \%$ \\
\hline$\geq 50$ & 6 & $19.35 \%$ \\
\hline \multicolumn{3}{|l|}{ Differentiation grade: } \\
\hline $\mathrm{G} 1$ & 7 & $22.58 \%$ \\
\hline G2 & 16 & $51.61 \%$ \\
\hline $\mathrm{G} 3$ & 8 & $25.81 \%$ \\
\hline \multicolumn{3}{|c|}{ Axillary node metastasis: } \\
\hline Present & 9 & $29.03 \%$ \\
\hline Absent & 22 & $70.97 \%$ \\
\hline
\end{tabular}




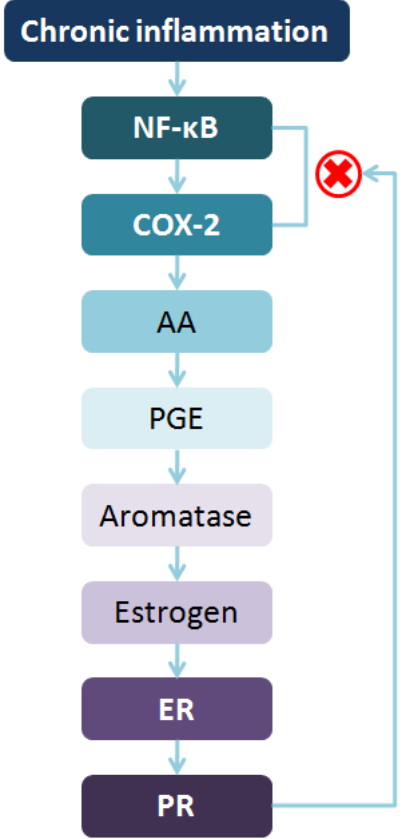

Figure 1: COX-2 is expressed in chronic inflammation, converting AA into PGE, leading to aromatase increase with subsequent increase of ER and PR. PR through NF-KB results in COX-2 lower expression.

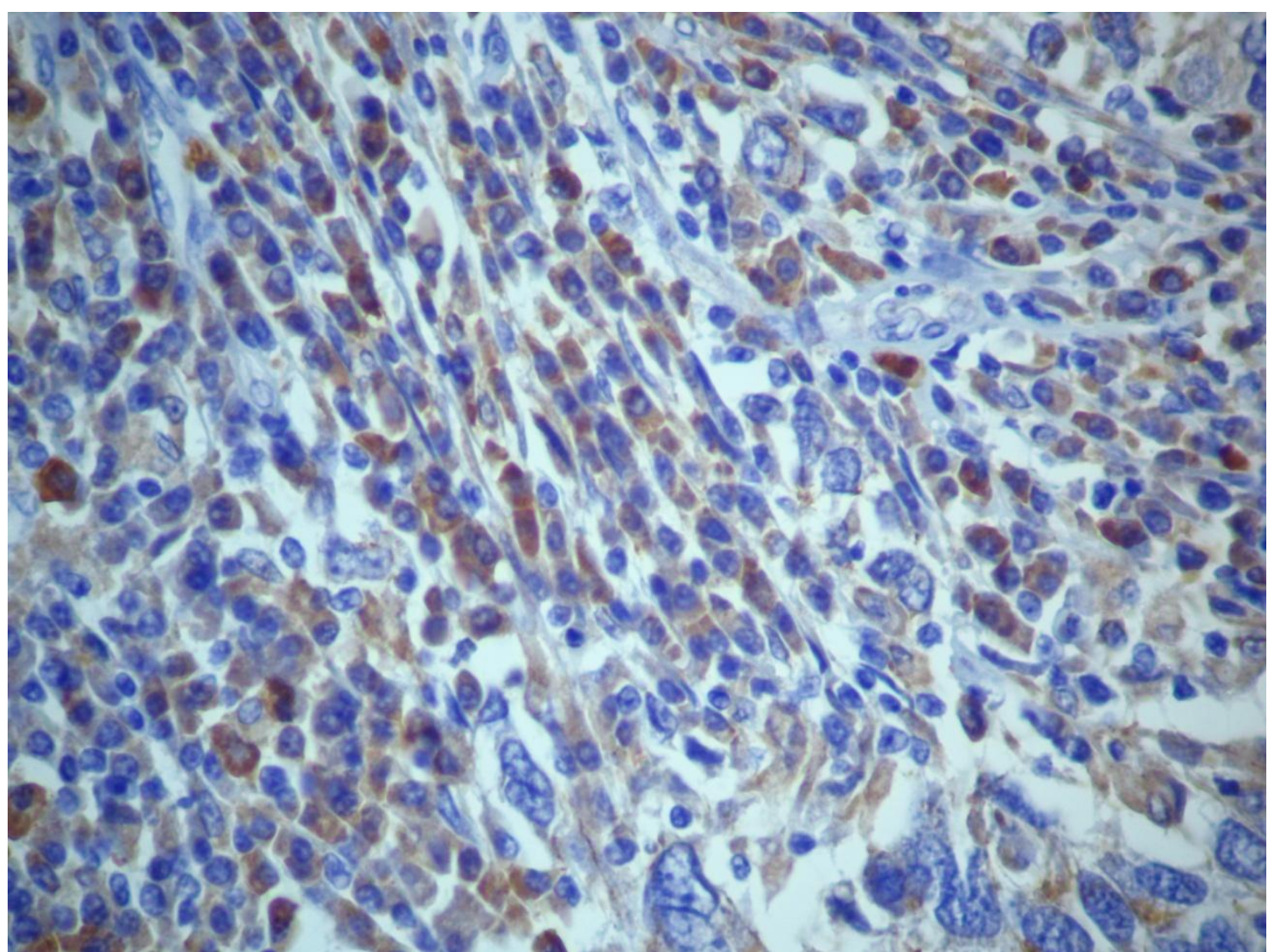

Figure 2: Immunohistochemical localization of COX-2 in ductal carcinoma (400x magnification). There is cytoplasmatic staining with COX-2 light expression. 


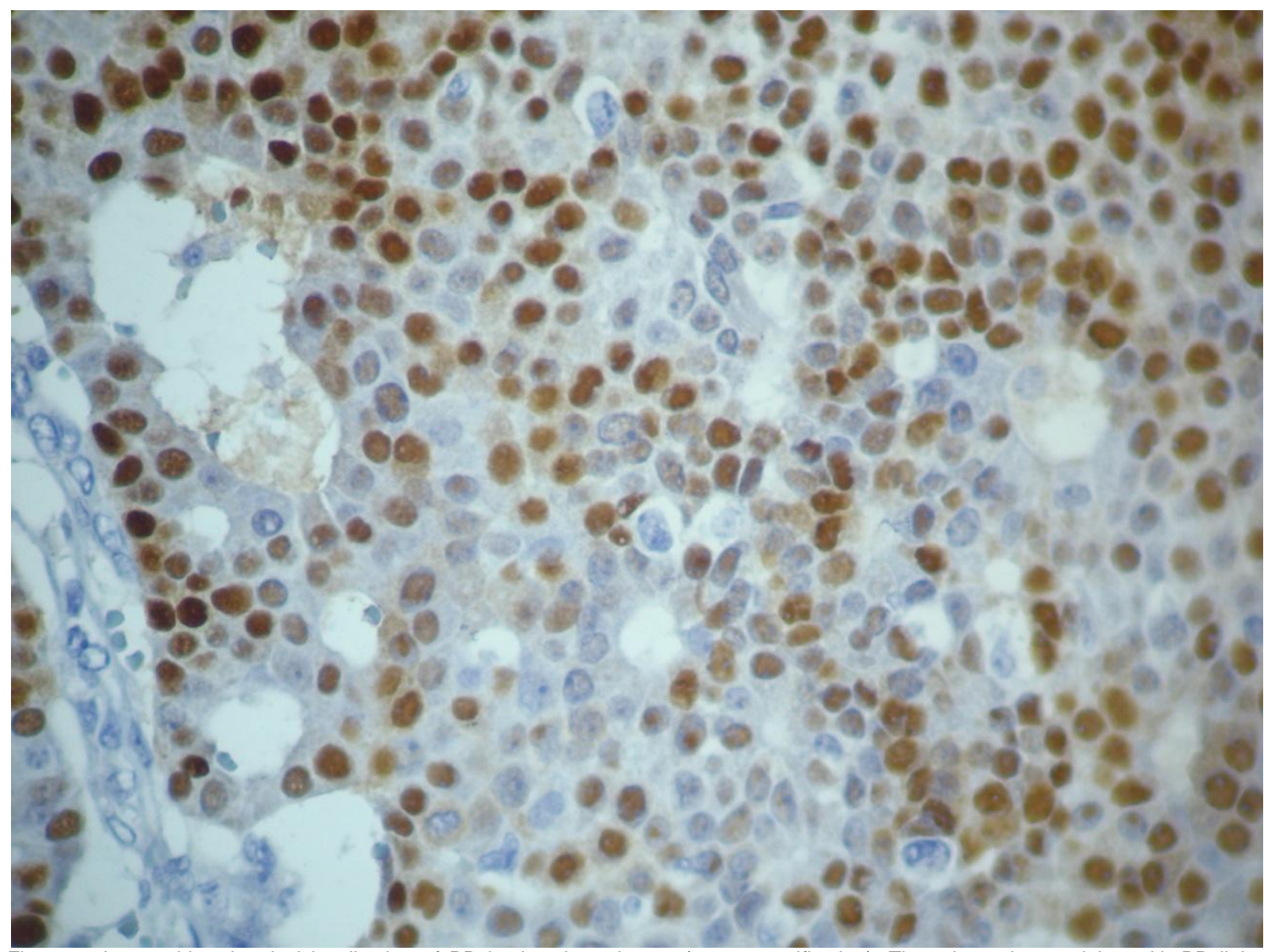

Figure 3: Immunohistochemical localization of PR in ductal carcinoma (400x magnification). There is nuclear staining with PR light expression.

Table 2: Correlation between COX-2 and PR expression.

\begin{tabular}{|c|c|c|c|}
\hline & COX-2 expression & COX-2 expression & Total \\
\hline PR positive status & $\mathrm{n}=11(35.48 \%)$ & $\mathrm{n}=3(9.68 \%)$ & $14(45.16 \%)$ \\
\hline PR negative status & $\mathrm{n}=9(29.03 \%)$ & $\mathrm{n}=8(25.81 \%)$ & $17(54.84 \%)$ \\
\hline Total & $20(64.51 \%)$ & $11(35.49 \%)$ & $31(100 \%)$ \\
\hline
\end{tabular}

a)

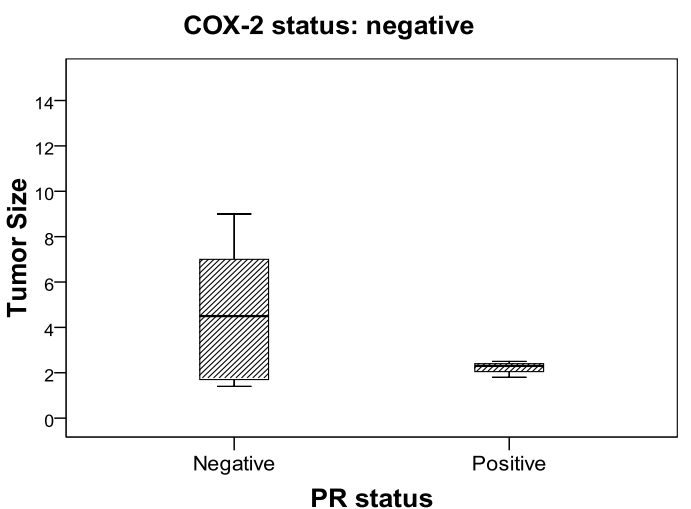

b)

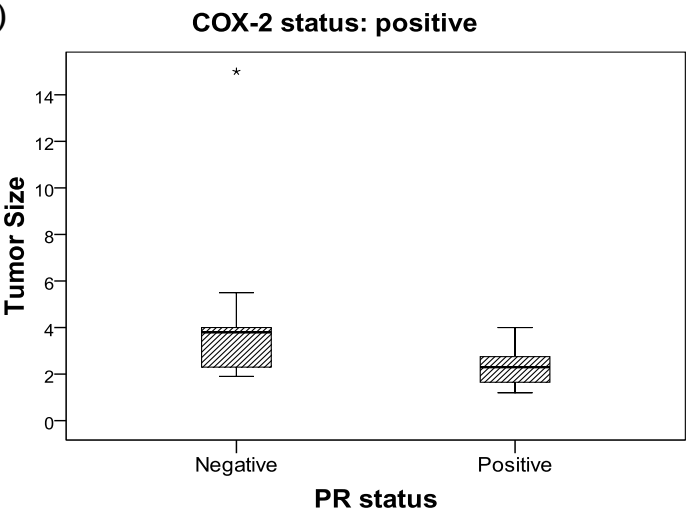

Figure 4: Correlation between PR expression and tumor size according to COX-2 expression. a) The COX-2/PR group is more heterogeneous and has higher mean than $\mathrm{COX}-2^{-} / \mathrm{PR}^{+}$group. b) $\mathrm{COX}-2^{+} / \mathrm{PR}^{+}$group has a lower mean and standard deviation than $\mathrm{COX}-$ $2^{+} / \mathrm{PR}^{-}$group. 
a)

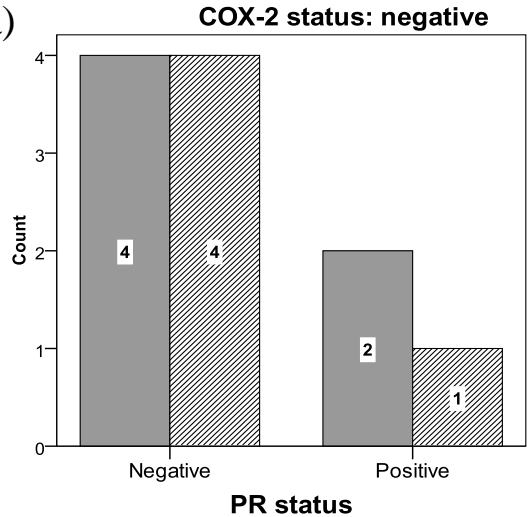

b)

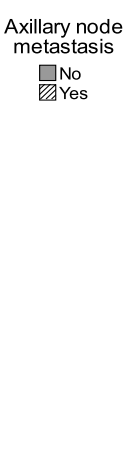

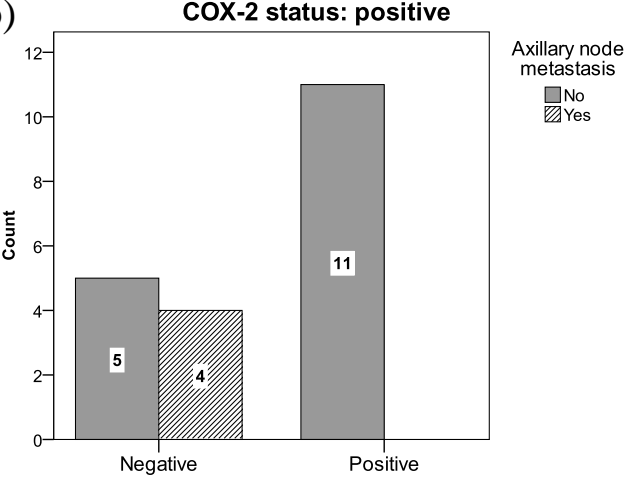

Figure 5: Correlation between PR expression and axillary node metastasis according to COX-2 expression. a) In COX-2/PR there is the same number of cases with and without axillary node metastasis, for PR status negative there are more cases without axillary node metastasis. b) $\mathrm{COX}-2^{+} / \mathrm{PR}$ has a higher number of cases with axillary node metastasis than $\mathrm{COX}-2^{+} / \mathrm{PR}^{+}$group, which has only cases without axillary node metastasis. 